\title{
Middle and high school science teacher identity considered through the lens of the social identity approach: a systematic review of the literature
}

\author{
Elizabeth A.C. Rushton ${ }^{\mathrm{a} *}$ and Michael J. Reiss ${ }^{\mathrm{b}}$ \\ ${ }^{a}$ School of Education, Communication and Society, King's College London, London, UK; \\ Orcid ID:0000-0002-6981-8797@RushtonDr \\ ${ }^{b}$ Department of Curriculum, Pedagogy and Assessment, UCL Institute of Education, \\ University College London, London, UK; Orcid ID: 0000-0003-1207-4229 \\ School of Education, Communication and Society, King's College London, London, SE1 \\ 9HN, UK; elizabeth.rushton@kcl.ac.uk *corresponding author
}

Elizabeth A.C. Rushton has worked within education as a high school teacher, as Director of Evaluation for an education charity that supports school student participation in STEM research and is currently a Lecturer in Geography Education at King's College London. Her research considers young people's experience of science in formal and informal settings and teacher professional development through collaborations with researchers and mentoring school student research.

Michael J. Reiss is Professor of Science Education at UCL Institute of Education, University College London and a Fellow of the Academy of Social Sciences. The former Director of Education at the Royal Society, he has written extensively about curricula, pedagogy and assessment in science education. 


\section{Middle and high school science teacher identity considered through the lens of the social identity approach: a systematic review of the literature}

Studies which consider science teacher identity continue to be a focus for education researchers, particularly given the persistent challenges to retain specialist science teachers. The proliferation of research in this area, without a unifying theoretical framework, has meant the literature is diverse, methodologies are varied, and coverage is patchy. This review article considers to what extent and in which ways the social identity approach (SIA) might provide a useful lens through which to consider middle and/or high school science teacher identity. In doing so, we synthesise the findings from 79 empirical and theoretical publications on science teacher identity in middle and/or high school settings, published since 2000. This review highlights the important role that shared identity and group membership play in developing and sustaining positive identities, including middle and/or high school science teachers' professional identities. We argue that the SIA provides education researchers with a greater understanding of how and why some middle and/or high school science teachers are able to form positive professional identities, whilst others are not. This understanding of both the importance of group membership in the social construction of identities and the processes through which memberships form could helpfully inform teacher education and professional development programmes.

Keywords: social identity; high/middle school; science teacher; social identity approach

\section{Introduction}

This article presents the findings of a systematic review of research that considers middle and/or high school science teachers' identities from the last twenty years, and explores how the 'social identity approach' (SIA) may provide a lens through which more fully and coherently to understand a body of literature that is diverse and somewhat disparate. Understanding the role of identity in shaping the experiences of middle and/or high school science teachers is important and timely given the challenging global context of teacher recruitment and retention (particularly chemistry and physics specialists) in a number of wealthy countries including the UK (Foster, 2018; Davies et al., 2016), Ireland (O'Doherty \& Hartford, 2018), the USA (García \& Weiss, 2019; Marco-Bujosa, McNeill \& Friedman, 2019), Australia (Weldon, 2018), and continental Europe (Eurydice, 2018), e.g. Sweden 
(Skolverket, 2017). High rates of teachers leaving the profession have been observed among specialist middle and/or high school science teachers in the first five years of their career (Allen \& Simms, 2017). We argue that by understanding the ways in which individuals develop their professional identity over the course of their careers, but especially during their training (or preservice year(s)) and first five years, school leaders and policy makers may be better able to develop support and training to address this retention challenge in a more personalised way. For example, recent research has highlighted the possible value of developing high school science teachers' professional identity through participation in science-focused research projects with their students as an alternative retention strategy to those based on financial incentives (Rushton \& Reiss, 2019). Given the persistent and geographically widespread challenges in middle and/or high school science teacher recruitment and retention, a systematic review of research that explores the concept of identity may further elucidate new approaches that seek to support middle and/or high school science teachers' professional development through identity formation. For example, when considering the retention challenge, a focus on identity may bring to the fore the challenges and affordances of different initial teacher education pathways in establishing and maintaining a strong and positive professional identity that enables individuals to persist through periods of challenge. Furthermore, the predominantly subject specialist role of a middle and/or high school teacher means that their relationship to their subject is better defined and more tightly connected to their identity (Beijaard, Meijer \& Verloop, 2004) than that of the more generalist primary or elementary teacher. For these reasons, a focus on middle and/or high school science teachers is appropriate, and this focus on middle and/or high school science teachers helps to distinguish our review from others which have more broadly considered science teacher identity (e.g. Avraamidou, 2014a).

Researchers have reviewed the place of identity in broad considerations of teacher identity (Beauchamp \& Thomas, 2009; Beijaard et al., 2004; Izadinia, 2013) as well as in reviews with a focus on science teacher identity (Avraamidou, 2014a; Glass, 2019). Through a review of 29 empirical publications, drawn from eight international science education peerreview journals published over a period of 12 years (2001-2013), Avraamidou (2014a) drew together the ways in which a general concept of identity had been used as a lens to explore a range of aspects of science education including: science learning, teacher preparation, teacher identity (reform-minded teacher identity; subject matter knowledge; competence, performance and recognition; life histories and context) and teacher identity development the lens of the social identity approach: a systematic review of the literature. Studies in Science Education. DOI: 10.1080/03057267.2020.1799621. 
(participation in field-based courses; informal science experiences; use of technology applications; use of curriculum materials; personal histories and biographies).

Although Avraamidou (2014a) demonstrated that identity has been used extensively as a lens in science education, the social identity approach has had limited application in education (Mavor, Platow \& Bizumic, 2017) and has been all but overlooked in considerations of the identity of science teachers (Rushton \& Reiss, 2019). The social identity approach (Haslam, Reicher \& Platow, 2011) brings together theories of shared or group identity (Tajfel \& Turner, 1979) and self-categorisation (Turner, Hogg, Oakers, Reicher \& Wetherall, 1987) to explain the role that social context has in determining an individual's sense of self and identity. In this way, the social identity approach asserts that an individual's sense of self is shaped by their internalised sense of social identity that they have derived from the groups to which they belong, rather than shaped only by their personal identity. This shared group identity shapes who individuals think they are, how they think and how they act. This understanding of the relationship between groups, social context and social connectedness has been applied to the health context to bring new perspectives to treating both physical and mental health conditions (Haslam, Jetten, Cruwys, Dingle \& Haslam, 2018). As education is a profession that is founded upon relationships and the social spaces in which they are formed and re-formed, we argue that a deep understanding the role of groups and social integration will further understandings of the ways in which middle and/or high school science teachers can form professional identities that endure through periods of challenge.

Avraamidou's (2014a) review considered research published in eight journals between 2001 and 2013; however, during the seven years since 2013 there has been a proliferation of work in this area. This current study therefore seeks to draw new insights from this burgeoning area of science education research by focusing on middle and/or high school science teacher identity and by drawing on a larger and broader body of literature (including doctoral theses) which should provide further coverage of emerging research. To the authors' knowledge, a review of the science teacher identity literature that considers this body of work through the lens of the SIA has not been published. Although science education researchers have recognised that identities are 'socially constructed and constituted' (Avraamidou, 2014a, p.165), we argue that the mechanisms which underpin, enable and promote these identities are less well understood and that this limits our understandings of the ways in which identities are developed and re-formed. Rather than the act of an individual 
informed by a social context, identity development is continuously corporate, where group membership is core to one's sense of self. Through the core concepts of identification, ideation, interaction, influence and ideology, the SIA brings to the fore the importance of group membership in identity formation and helps us to understand why, how and when positive professional identities might be promoted and challenges alleviated. Thus, the review seeks to bring together research in this area from the last twenty years and explore new ways of understanding the mechanisms of identity formation in the context of middle and/or high school science teachers. The review addresses the following questions:

- How has the concept of identity been used to explore the professional experiences of middle and/or high school science teachers?

- To what extent, and in which ways, does the social identity approach (SIA) provide a useful lens through which to consider identity literature from the field of education, specifically for middle and/or high school science teachers?

The first part of the article describes the theoretical framework of the SIA and the ways previous research has considered the SIA in the field of education. Subsequently, we present a systematic review of publications, conducted within the last twenty years, that report on findings from research into middle and/or high school science teacher identity. Specifically, the findings of 79 empirical and/or theoretical publications are analysed to explore whether the SIA provides a useful framework to consider the place of identity in the role of the middle and/or high school science teacher and how future research could be framed by the SIA.

\section{Theoretical framework}

\section{Social identity approaches and education}

Social identity approaches combine the theories of social identity (Tajfel \& Turner, 1979) and self-categorisation (Turner et al., 1987) which together are referred to as the social identity approach (Haslam et al., 2011). These approaches suggest that a person's sense of self is largely determined by their social context and the groups to which they belong and identify with, and that people seek to develop and maintain a positive view of themselves by comparing themselves and their group memberships in a more positive light than their alternative 'outgroups' (Tajfel \& Turner, 1979; Ellemers \& Haslam, 2012). Social identity theory suggests how groups form (Turner, 1982) whereas self-categorisation theory suggests 
when groups form and recognises that this is part of a context-sensitive, self-categorisation process (Turner, 1982; Oakes, Haslam \& Turner, 1994).

Education is a collaborative process that involves groups of people and yet the SIA has only recently been considered in relation to education research (Mavor et al., 2017). In a review of current research, Haslam (2017) identifies that five 'I's that have significance for social identity and education: Identification, Ideation, Interaction, Influence and Ideology. Identification is based upon the idea that group membership shapes an individual's behaviour to the extent that their social identity derived from this group membership is incorporated into their sense of self. Research considering identification and teachers has shown that levels of identification are good predictors of engagement (Christ, van Dick, Wagner \& Stellmacher, 2003), job satisfaction (van Dick \& Wagner, 2001) and self-reported physical (van Dick \& Wagner, 2002) and psychological (van Dick \& Wagner, 2001) health and well-being.

Ideation, what people identify with, is as important as mutual identification. Group norms, or informal rules and guidelines, inform how individuals act and are developed from ideation. These shared norms change over time and shape behaviour in terms of what a group does and the ways members of group perceive they and others should behave. For example, what students are told about the groups they identify with (e.g. gender, race, class, ability) shapes their behaviour in both school (Mutjaba \& Reiss, 2013; Boucher \& Murphy, 2017) and university (Cruwys, Gaffney \& Skipper, 2017) settings. Interaction is what develops and galvanises social identities (Haslam, 2017) and this interaction has the capacity to shape the extent to which individuals feel part of the group and therefore can increase or limit their academic and intellectual performance (Reynolds et al., 2017). Often, social interaction is key to the capacity for social identities to have their impact (Haslam, 2017; Thomas et al., 2017). Influence, Haslam (2017) suggests, is what makes identification, ideation and interaction possible; it is the extent to which leaders can shape the attitudes, intentions and behaviour of followers. Levels of influence are determined by how much followers socially identify with others, including their leaders. Ideology pervades education, and multiple aspects of the educational landscape (e.g. class, political views, gender, 'race', faith) provide teachers with the context for identification, ideation and interaction (Haslam, 2017). How students identify themselves as a part of an education system that is imbued with different and competing ideologies has consequences. For example, do students identify as learners or consumers? Are teachers identified by students as educators or service providers? The extent to which students identify with their teachers and education institutions and their associated ideologies the lens of the social identity approach: a systematic review of the literature. Studies in Science Education. DOI: $10.1080 / 03057267.2020 .1799621$. 
also shapes their experience; for example, identity continuity at university can be much easier for students from middle class backgrounds than for those from disadvantaged backgrounds (Haslam et al., 2011). Thus far, studies that consider ideation and interaction in education have predominantly focused on student identities, including studies that explore female students' experiences of STEM subjects at school and in higher education (Boucher \& Murphy, 2017), bulling (Jones, Livingstone \& Manstead, 2017) and socio-economic factors relating to educational experience (Jetten, Iyer \& Zhang, 2017). Rushton and Reiss (2019) identified that, apart from the work of Mavor et al. (2017), social identity perspectives have yet to feature in research focused upon teachers and this review seeks to address this gap in current understanding. Drawing on the research of Haslam (2017), we argue that the SIA is an appropriate lens for science education because promoting social connectedness and integration, so that those involved have a shared sense of 'us', will further support education that is meaningful, purposeful and effective for all participants.

\section{Methods}

The review took the form of a systematic review, where a careful and logically coherent search of a body of literature enables the synthesis of findings from related studies (e.g. Amundsen \& Wilson, 2012; Avraamidou, 2014a; Bennett et al., 2018). The movement in favour of systematic reviews in education has come principally from their increasing usage in medicine over the last thirty years (Moons et al., 2018). The fundamental argument in favour of such reviews is that they substantially reduce the bias that almost inevitably attends conventional literature reviews where authors tend to privilege work with which they are already familiar. At the same time, systematic reviews in education are not a universal panacea. In particular, it has been argued that they privilege quantitative studies (Andrews, $2005)$ and it was the case that early systematic analyses in education sometimes conflated these with meta-analyses (in which statistical methods are used to aggregate across quantitative studies). It remains the case that, at the very least, systematic reviews have the benefit of making explicit why certain studies are included and others are not.

There were four stages in the review:

1. Discussion of review strategy

2. Identification of the literature - using inclusion and exclusion criteria (see below).

3. Extraction of the key information from the literature.

4. Synthesis of the literature through the lens of the social identity approach. 


\section{Discussion of the review strategy}

Discussion of the review strategy was undertaken by the two authors based upon published guidance (Amundsen \& Wilson, 2012; Gough, Oliver \& Thomas, 2012; Siddaway, Wood \& Hedges, 2019). This included:

1. Discussing routes to identifying literature (e.g. database selection) based upon the second author's prior experience of conducting systematic reviews in the field of education.

2. Identifying a shared understanding of the term 'identity' in the context of middle and/or high school science teachers, where identity describes the ways in which middle and/or high school science teachers understand themselves, or have a 'sense of self', and present themselves externally in the context of their professional role.

3. Determining a focus on identity as a conceptual device that is self-identified by the authors of research, and so includes differences in definition and conceptualisation. We chose to focus on the conceptual rather than empirical understanding of identity so that a broad range of understandings from across the field of science teacher identity research could be considered within the scope of this review, to ensure as far as is possible that the review is representative of research undertaken in this area up to this point in time.

4. Agreeing a specific time frame for the review. We decided to focus upon literature published over the last twenty years as, in this relatively recent area of science education research, this provided a period that enabled a detailed review of a significant number of studies. However, a certain amount of research that considers school science teacher identity was published prior to 2000 (e.g. Volkmann \& Anderson, 1998) and, due to the agreed upon time frame, this research was not included and therefore, this review does not benefit from insights published prior to 2000. In fact, only four of the final 79 publications that we include in our review come from the first five years of our time frame, which suggests that relatively few additional publications would have been included had we extended our time frame backwards.

5. Agreeing upon a focus which included preservice, beginning and qualified middle and/or high school science teachers. We decided to include research that considered 
the experiences of individuals who were training to become middle and/or high school science teachers as well as those teachers at the start of their post-qualification teaching practice (also described as 'beginning' teachers) and more experienced qualified teachers. This enabled the review to consider the experiences of individuals who were new to science teaching. We felt this to be of importance as teacher attrition rates are highest in middle and/or high school science teachers who are in the first five years of their careers (Allen \& Simms, 2017). The term 'preservice' has a variety of uses across the science education literature; it can be used to describe trainee teachers in a university phase of teacher training before undertaking any teaching practice but it can also be applied to those who have been working in a classroom for a year or more. In this synthesis, a broad application of the term is used: 'preservice' is applied to teachers who were not qualified at the time of the study and were participating in some form of teacher education or training programme. This therefore means that 'preservice' could describe individuals with a range of teaching experience as such programmes vary in length from approximately nine months to four years.

6. Agreeing an identification strategy to be used in the subsequent stage of literature identification that began with a search of five electronic databases, using Boolean searches over a twenty-year period, beginning in 2000. This was supplemented with a search using Google Scholar for items published since 2015. This additional search, over a shorter time period, was to ensure, as far as possible, that only relevant, more recently published literature was included in the search.

7. Identifying the keywords to be used in the subsequent stage of literature identification: science, teacher, identity, formation, development.

\section{Identification of the literature}

The following steps were taken to identify material to be included in the systematic review, having been discussed and refined by both authors throughout the process. The first five steps were undertaken by the first author and the sixth step by the second author.

1. A search of the following five electronic databases for literature published in peer review journals, conference papers, proceedings, reports and doctoral theses: the British Education Index (BEI), the Education Resources Information Centre (ERIC), eTHOS, PsychINFO and the Social Science Citation Index (SSCI) using the keywords Rushton, E. A. C. \& Reiss, M. J. (2020) Middle and high school science teacher identity considered through 9 the lens of the social identity approach: a systematic review of the literature. Studies in Science Education. DOI: 10.1080/03057267.2020.1799621. 
identified by the authors in the previous stage: science, teacher, identity, formation, development.

2. The first stage of Boolean searches of 'scienceANDteacherANDidentityANDformationANDdevelopment' constrained the results such that fewer than 20 results were found. Subsequent Boolean searches of 'scienceANDteacherANDidentityANDdevelopment' and 'scienceANDteacherANDidentityANDdevelopment' gave a slightly larger pool of potential publications but was still amounted to fewer than 50 items. A third Boolean search of 'scienceANDteacherANDidentity' produced a pool of slightly over one thousand publications to review, and this was the pool from which the review then proceeded.

3. Abstracts of the 1088 peer-reviewed journal articles, conference papers, proceedings, and reports identified in the first step were read to determine if the research described identity in the context of middle and/or high school science teachers. This created a list of 131 items of research to read fully.

4. A search was made using Google Scholar for items published since 2015 using the term 'science teacher identity'. This identified 74,000 results, of which the first 250 items presented by Google Scholar as being the most relevant were reviewed. This resulted in seven items being added to the 131 research items to be read in full, a total of 138 items at the end of this stage.

5. Using AI translation software, the search term 'science teacher identity' was translated into each of the following eight languages: French, German, Italian, Spanish, Swedish, Norwegian, Danish, and Portuguese. These languages were identified by the authors as those frequently used when writing about science education for academic purposes, and the common Latin script enabled the use of AI translation software by the authors. We accept that we have not accessed other languages, in particular Arabic, Chinese, Japanese and those that use Cyrillic script or the various scripts used in India. These translated terms were then separately entered as search terms into Google Scholar to identify items published since 2015. This identified a total of 56,170 results across the eight languages. Of these, the first thirty items presented by Google Scholar as being the most relevant for each language were reviewed using AI translation software, a total of 240 items. This resulted in one item 
being added to the 138 items to be reviewed in full, a total of 139 items at the end of this stage.

6. Twenty three key informants working in the area of science teacher identity whose research (published since 2015) had been noted during the previous two steps of the review were identified. These key informants were contacted by email to identify potentially relevant publications, particularly 'grey literature' and this revealed 29 items to be reviewed. This includes an item provided by one of our reviewers. One of these items was an edited collection of 15 chapters, 14 of which were empirical and/or theoretical studies focused on science teacher identity. As such, these 14 items were considered individually which gave a total of 43 items identified in this stage to add to the items identified in previous stages, a total of 182 research items.

\section{Extraction of key information from the literature}

1. When reading the 182 research items, specific information was entered in an Excel table: first author, year of publication, journal of publication, (database) source, title, and description of the research purpose and methods.

2. Through this review of the 182 research items, we developed the following inclusion criteria:

a. Self-identified by the authors of the research item as including the concept of identity as a focus of the research.

b. An empirical or theoretical study.

c. Focus on teachers of science in middle and/or high school settings (teaching students aged 11-18 years).

d. Date of publication in the range 2000-2019 for research items included in one or more of the five electronic databases consulted.

e. Date of publication in the range 2015-2019 for research items located using Google Scholar and/or key informants.

3. Both reasons for inclusion and exclusion were listed in an Excel table. Examples of studies that were reviewed and excluded included those that focused on primary or elementary science teacher identity (e.g. Chen \& Mensah, 2018; Naidoo, 2017) and studies that focused on the professional development of high school science teachers but did not include the concept of identity (e.g. Ufnar \& Shepherd, 2019). Borderline Rushton, E. A. C. \& Reiss, M. J. (2020) Middle and high school science teacher identity considered through 11 the lens of the social identity approach: a systematic review of the literature. Studies in Science Education. DOI: $10.1080 / 03057267.2020 .1799621$. 
cases were discussed by the authors to make an agreed determination. For example, Chetcuti (2009) explored the gendered identities that teachers bring to the science classroom drawn from their 'personal practical knowledge'. As the study considers the development of gender-inclusive pedagogies rather than the identity development of the teacher, we determined that the study was beyond the scope of this review. Application of the inclusion criteria resulted in a total of 74 research items.

4. The 74 research items were cross-checked with the 29 peer-reviewed articles identified in Avaraamidou's review (2014a) in order to identify any further items of research appropriate to the focus of the current review as, to the authors' knowledge, Avaraamidou's work is the most recent previous review literature that considers science teacher identity. Eleven additional references were identified in Avraamidou (2014a) and of these, five items were consistent with the inclusion criteria of this study and were therefore added to the review literature.

5. This resulted in a total of 79 research items included in this review (Table 1). Of the 79,17 are available doctoral dissertations (22\%) and 55 items (70\%) are peerreviewed articles, published in a total of 27 journals (Table 2). Six items are chapters in an edited book (Avraamidou, 2016) and one item is a paper presented at a conference. Research items from English-speaking countries make up the majority (81\%) of the research sample: the USA (52), UK (7), Australia (3) and New Zealand (1), although the review does include research with contributions and perspectives from ten other countries (Table 3). This suggests that research that considers the concept of identity within studies of school science teachers is of international interest. Of the 79 items, 43 (54\%) have been published between 2015 and 2019 inclusive, which indicates the significant growth of literature since the publication of Avraamidou's (2014a) review and further justifies the need for additional work in this area.

\section{Limitations}

There are limitations associated with how we obtained the literature for our systematic review. The decision to focus on studies which considered the professional identity of middle and/or high school science teachers meant the exclusion of research that considers the experiences of science teachers who teach in elementary schools or settings which cater for those aged over 18 years. The chosen time frame for the review of 2000-2019 for material 
accessible via academic electronic databases excluded material published prior to 2000 . The volume of results generated through a Google Scholar search of relevant material published between 2015 and 2019 meant that only a very small fraction $(<1 \%)$ of the 74,000 hits were reviewed and the chosen time frame for the Google Scholar search did not include material available before 2015. Given these limitations, it is highly likely that other studies that consider identity in the context of middle and/or high school science teachers exist and that these could have provided new and relevant insights to our review. A further limitation of our review is the predominance of research conducted in Anglophone countries (Australia, New Zealand, UK, USA make up $81 \%$ of the publications included in the review). Furthermore, our review did not include any research conducted in China, India or Russia and, as such, our review cannot and does not make any claims about the universality of our findings.

[Insert Table 1 near here]

[Insert Table 2 near here]

[Insert Table 3 near here]

\section{Synthesis of the literature}

The starting point for this review was to consider to what extent and how the SIA provides a useful lens through which to consider teachers' professional identity, specifically science teachers working in middle and/or high schools. The synthesis of the literature draws on the framework synthesis approach as described by Gough et al. (2012). When synthesising the literature identified during the identification stage, the conceptual framework of the SIA provided a starting point rather than a rigid structure, and this evolved during the synthesis as we became more familiar with the literature being reviewed. As noted by Gough et al. (2012), the framework synthesis approach broadly includes five stages, although these are not always distinct as, at times, stages overlapped:

1. The research items were reviewed to identify central research foci and these and the methods were summarised (Table 1).

2. Three overarching clusters were identified by the authors based upon common central research foci within each cluster: research that focused on (1) preservice teachers, (2) qualified teachers, and (3) theoretical research and/or conceptual models of identity development. 
3. Further stages of review and synthesis formed the studies into five groups of research: (1) studies that broadly consider the concept of identity within research focused on the development of middle and/or high school science teachers; (2) studies that focus on a specific aspect of a teacher's own context or experience; (3) studies that focus on an aspect of the school and/or teaching context; (4) the role of teacher training programmes; (5) the role of professional development opportunities in the formation of identity (Table 4).

4. The 79 research items were reviewed for a second time against the identified clusters and groups to ensure coherence.

5. The synthesis of the literature took place in the fifth and final phase, to explore the items for associations and differences and to suggest what these findings might mean in the context of the social identity approach. The lens of the SIA was used flexibly and responsively to enhance and develop understanding of a substantial body of research rather than as a rigid and fixed set of theoretical propositions. For example, the social identity approach provided a way of classifying studies, proposing alternative hypotheses and drawing out new interpretations of phenomena reported in science teacher identity research.

[Insert Table 4 near here]

In the following section we present our synthesis of the 79 research items identified, grouped into five distinct but related areas (Table 4). These include: (1) studies that broadly consider identity development in teachers, using a variety of theories, frameworks and models; (2) studies that focus on a specific aspect of a teacher's own context or experience, such as cultural contexts and career changers; (3) studies that focus on an aspect of the school and/or teaching context, including teaching inquiry and new curricula; (4) studies that consider the role of the training programme, for example those that are based in alternative institutions or situated in reform-minded or social justice frameworks that are explicit; and (5) studies that consider the role of professional development opportunities, including leadership, STEM research and blogging. There are, of course different ways to approach grouping these studies. For example, research that considers identity development in middle and/or high school science teachers who participated in training programme located in an alternative institution have been allocated in this review to Group four. However, in an alternative approach, different reviewers might have chosen to group research according to career stage 
(e.g. preservice, beginning, early career, experienced teachers). We have chosen not to do this in Groups one, two and three as we felt that, where possible, it would be a more fruitful approach to read across the experiences of teachers at a variety of career stages in response to other common themes such as 'teachers of inquiry', 'career changers' and 'cultural context'. Studies which consider middle and/or high school science teacher professional development have been grouped separately (as opposed to forming part of the wider consideration of teachers' own contexts or experience as a sub-set of Group two) because the studies included in Group five only considered the experience of qualified teachers. We argue that the professional development needs of preservice and qualified teachers are distinct, and so it is more appropriate to consider identity in relation to professional development separately.

\section{Group one: Studies that broadly consider the concept of identity development within research focused on middle and/or high school science teachers}

Twenty one studies broadly explored the concept of identity in the development of middle and/or high school science teachers, including those who were preservice teachers, qualified teachers and studies which discussed models of identity development or presented theoretical considerations of identity literature (Table 4).

Studies were undertaken over a variety of timespans, ranging from responses to a single survey (Beijaard et al., 2000) to in-depth individual case studies examined over a fouryear period (Manning, 2017). Twelve empirical studies were based upon qualitative research approaches, with two studies predominantly focused on quantitative data gathered from survey responses (Beijaard et al., 2000; Niewswandt, Barrett \& McEneaney, 2013). Hsu et al. (2017) quantitatively analysed discourse patterns in learning autobiographies. Consistent with the wider body of literature considered for inclusion in this study, research is predominantly from English-speaking countries including the UK (Irving-Bell, 2018; Manning, 2017; Woolhouse \& Cochrane, 2015) and the USA (Chung-Bailey \& Parsons, 2019; Derenoff, 2016; El Nagdi et al., 2018; Hong et al., 2017; Hsu et al., 2017; Kang, 2011; Nichols et al., 2017; Richardson, 2019), but also includes studies from Brazil (Dominguez et al., 2015), the Netherlands (Beijaard et al., 2000) and Chile (Ortega et al., 2015).

To begin, we consider three broad theoretical perspectives on science teacher identity from Avraamidou (2014a), Glass (2019) and Roth (2016) to provide an overview of recent considerations of science teacher identity at the outset of this synthesis. As outlined earlier in 
this review, Avraamidou (2014a) reviewed and synthesised the findings from 29 peerreviewed articles to better understand the ways in which identity has been used as a lens to examine science teacher learning and development. She identified three broad areas of agreement across the 29 articles:

(a) teacher identity is socially constructed and constituted; (b) teacher identity is dynamic and fluid and constantly being formed and reformed; and (c) teacher identity is complex and multifaceted, consisting of various sub-identities that are interrelated. (p.165).

Key limitations of the research identified by Avraamidou (2014a) included, (1) the lack of a clear and coherent conceptualisation of science teacher identity, (2) the disconnect that exists between science teacher identity research and science education reform, and (3) a need for a greater understanding of the ways in which different contexts shape and influence identity development. Large-scale, longitudinal studies that include quantitative data sets were methodological improvements suggested by Avraamidou (2014a). Through our synthesis, we draw on research that includes 43 publications published after 2014 and we will consider whether this more recent body of research addresses these limitations and, by doing so, whether this expands our understanding of the identity formation of science teachers so that it might contribute insights for initiatives and institutions that seek to improve the recruitment and retention of science teachers in middle and high school settings.

In response to Avraamidou (2014a), Glass (2019) and Roth (2016) gave further perspectives on notions of science teacher identity. Glass (2019) highlighted the difference between 'science' and 'science teacher' identities, arguing that science teacher identity is a 'community identity' formed out of an individual's relationship to the teaching profession whereas a science identity is a personal affinity towards science. Glass (2019) emphasised the importance of context in shaping multiple forms of identity and, argued that these manifestations of identity were derived from and rooted in an individual's core identity. In contrast to the entirely theoretical contribution of Glass (2019), Roth (2016) shared an autobiographical account of developing a high school science teaching identity in different cultural contexts and professional roles. Roth (2016) drew on two theoretical concepts when describing identity in these contexts: firstly, through the Deweyan category of experience, including a person's interaction with their environment; and secondly, through the 
Vygotskian concept, that 'we become ourselves through others' (Vygotsky, 2005, p.1021). Roth (2016) argued that exploring identity through a series of life events enabled an understanding of the ways in which identity is shaped by both the professional context and the ways in which a high school science teacher's own personal context interacted with their professional identity. Both conceptualisations of identity shared by Glass (2019) and Roth (2016) underline the importance of context; however, Roth (2016) argued that identity should not be understood as a composite of a person's micro-identities which is in contrast to the multiple manifestations of identity conceptualised by Glass (2019).

We suggest that the areas of consensus in the science teacher identity that Avraamdiou (2014a) outlines in her systematic review are consistent with the SIA. The social construction of identity, the dynamic nature of identity and the multifaceted nature of identity are all consistent with an understanding of the importance of group membership and shared identity in forming and influencing the individual self. We would agree with the notion of science teacher identity as community identity presented by Glass (2019) and the importance of others in identity formation as highlighted by Roth (2016), but would contend that science identity entails an affinity with both science and the science community and therefore requires, group membership, at least to some extent, rather than being only a solo or personal endeavour.

Reading across these three theoretical perspectives and a further 18 publications included in this aspect of our review, three areas of synthesis were identified: (1) the variety of conceptual frameworks and models used to explore the construct of identity; (2) the recognition of both the individual and social elements to identity that emerged from both empirical and theoretical research; and (3) the relative importance of science/subject matter identity and teaching identity when understanding a middle and/or high school science teacher's professional identity.

\section{Conceptual frameworks and models utilised to underpin understandings of 'identity'}

All 21 publications recognised that identity was a complex concept and, perhaps unsurprisingly, highlighted the importance of understanding how middle and/or high school science teachers' identities are developed and negotiated. Authors of each publication set out the conceptual framework that their study drew on when considering identity. Common to all publications was a recognition that identity was a dynamic, multidimensional and fluid construct that was universally recognised to change over time. 
Two conceptual models of science identity were presented in the literature reviewed: The Dynamic Systems Model of Role Identity (DSMRI) (Garner et al., 2016; Garner \& Kaplan, 2018) and The Science Teacher Identity (STI) (Chi, 2009). Both models referenced Gee's (20001) understanding of the four types of identity that are socially and culturally constructed by: nature (N); institutions (I); discourse (D); and affinity (A). The DSMRI described teacher learning and teacher identity development as integral processes with four interrelated components, guided by the cultural context, contributing to the role of a teacher: (1) ontological and epistemological beliefs; (2) purpose and goals; (3) self-perceptions and self-definitions; and (4) perceived action and future possibilities (Garner et al., 2016; Garner \& Kaplan, 2018). Garner and Kaplan (2018) suggested that the DSMRI provided a teacher with a framework through which to interpret their experiences and enact their role, developing their identity in a dynamic and iterative process. Applying the DSMRI to a case study of a veteran high school science teacher, Garner et al. (2016) argued that three role identities were enacted during the professional development programme: teacher, learner and scientist or content expert (Garner et al., 2016). Understandings drawn from the application of the DSMRI suggested that teachers' learning within professional development contexts is dynamic, complex and is shaped by the design and delivery of the professional development program (Garner et al., 2016; Garner \& Kaplan, 2018). Chi (2009) developed a model of Science Teacher Identity (STI) with nine dimensions: personal learning experience; knowledge and skills; community practice; science teaching practice; degree of success; social respect; belief and value in science teaching; intrinsic satisfaction; and representation. Chi developed a 48-item questionnaire to provide a score of STI and argued that this instrument could be used to measure changes in science teacher identity, for example before and after a teacher's participation in professional development program. As one would expect, STI scores were positively associated with increased teaching experience, knowledge and skills and participation in professional development opportunities (Chi, 2009). The nine dimensions of the STI suggested by Chi are closely related to the four concepts of the DSMRI (Garner et al., 2016; Garner \& Kaplan, 2018). For example, the dimensions of personal learning experience, belief and values and representation from the STI (Chi, 2009) could incorporate the same material found in the ontological and epistemological beliefs component of the DSMRI (Garner et al., 2016; Garner \& Kaplan, 2018). Likewise, the dimensions of science teaching practice and degree of success (Chi, 2009) could be understood as part of a teachers' perceived actions and future possibilities (Garner et al., 
2016; Garner \& Kaplan, 2018). However, a difference between these two models is that Chi (2009) explicitly describes social and community aspects to such dimensions (community practice, social respect), whereas this is only implied in the four concepts of the DSMRI (Garner et al., 2016; Garner \& Kaplan, 2018). We contend that the social and community aspects of identity should be an explicit part of a middle and/or high school science teacher identity model, as the SIA recognises that the identity derived from group membership is incorporated into an individual's sense of self and shapes their behaviour.

The work of Gee (2000) was explicitly incorporated in the conceptual frameworks of three further studies in this group that were focused on middle and high school science teachers categorised as 'exemplary' (Deneroff, 2016), 'preservice' (Hsu et al., 2017) and 'experienced' (Richardson, 2019). In a three-year ethnographic study of the identity construction and teaching practices of an urban high school science teacher, who was described as being an exemplary teacher of inquiry, Deneroff (2016) drew on Gee (2000) to suggest that science teaching is not the summation of knowledge, values and beliefs but should be understood as being socially constructed and that this understanding should inform the design of professional development programmes for teachers that enable teachers to consciously problematise identities if they are to transform their teaching practice. Both research that is focused on preservice middle school science teachers (Hsu et al., 2017) and that which examines experienced high school science teachers (Richardson, 2019) drew from Gee (2000) the concept of 'affinity', which Hsu et al. (2017) articulated as 'shared practices with group members'. In an analysis of written teaching philosophies and learning autobiographies from 38 preservice middle school science teachers, written as part of their final year of a four-year university-based teacher education program, Hsu et al. (2017) found that affinity identity was the most important factor in shaping science learning experiences and preservice science teachers' teaching philosophies. However, affinity identities were mediated in slightly different ways. When preservice teachers discussed their affinity identities as learners, they emphasised the importance of the social context of the classroom and the collective practices they had experienced. However, when the same preservice teachers discussed their affinity identities as future science teachers, they focused more closely on their own individual characteristics as teachers. In a study that considered the reasons why science teachers remain in the profession, Richardson (2019) also recognised the importance of affinity identity, and referenced the work of Gee (2000) to assert that teachers who are aware of their professional identities are more likely to be retained in the profession. 
In an examination of the experiences of 20 mid- and late-career high school science teachers, Richardson (2019) suggested that affinity identity is more important for mid-career teachers' identity development, with this cohort of teachers placing greater importance on developing connections with colleagues than late-career teachers, whose institutional identity held more significance. Richardson (2019) suggested that this is most likely due to late-career teachers having greater contact with authority figures within and beyond their schools and because they often held leadership roles themselves.

Other frameworks that have been utilised by researchers and are consistent with Gee's (2000) identity theory that recognises that an individual's identity is shaped by their social context, include the tripartite division of identity by Day (2006) as (1) professional - what constitutes a good teacher, (2) situated - the school context, and (3) personal - life outside of school, with each having competing sub-identities that are held in balance or imbalance. In her exploration of five urban high school science teachers' experiences over a four-year period, Manning (2017) argued that teachers' personal and situated identities were more influential in determining teacher retention or attrition than professional identities. Specifically, teachers' personal resilience, notions of choice over whether to leave their role and teacher perceptions of their ability and the school's ability to mediate professional concerns (e.g. workload). Manning (2017) noted that it is somewhat surprising that professional identity is the least significant of these three components to identity, particularly when it is often government policy, rather than school policy or individual choice that determines issues such as workload and accountability measures. The importance of pragmatism (that is, teachers' choices to stay or leave their roles are often determined by factors such as needing employment to meet financial commitments, rather than job satisfaction) is recognised by Manning (2017) in high school science teachers when they are negotiating challenging contexts. This understanding of pragmatic identities is arguably more consistent with Dominguez et al. (2015)'s view of interacting objective (e.g. constraints of a teacher education programme) and subjective (e.g. individuals' previous experiences) identities rather than Day's (2006) delineated, yet overlapping, personal, situated and professional identities. Nichols et al. (2017) explored identity development through a framework of emotions, and argued that emotional experiences that conflict with an individual's expectations of what it is to be a teacher provided opportunities for 'identity work', where teachers actively and explicitly explored what it is to be a teacher. This framework of emotions intersects an individual's personal and professional identity and is 
consistent with an understanding of professional identity development that pragmatically (Manning, 2017) interacts across both subjective and objective aspects of identity (Dominguez et al., 2015).

In their study of three preservice high school teachers' conceptions of their science teacher identities, Chung-Parsons and Bailey (2019) recognised that 'identities reflect the individual to include a sense of belonging to one or more larger social groups, such as the teaching profession' (p.40) Through a consideration of the findings of Schachter and Rich (2011), Chung-Parsons and Bailey (2019) suggested that in order to facilitate students' development of science identity, teachers should 'identify with scientists and the scientific community, and have a science identity that manifests itself in their teaching identity' (p.40). Chung-Parsons and Bailey (2019) found that teachers who undertook a year-long teacher accreditation course, (often following a three year undergraduate science-based degree): (1) viewed their science identity as distinct from their science teacher identity and that only their science identity was part of their core identity, (2) their science identity was only used in two contexts - teaching science content and analysing student work to facilitate learning - and (3) their teacher identity became dominant over their science identity only in the sociocultural context of science classrooms (Chung-Parsons \& Bailey, 2019). In citing Lave (1996), Wenger (1998) and Burke and Stets (2009), Chung-Parsons and Bailey (2019) recognised the social context and reciprocal nature of identity development. However, what is perhaps missing from their analysis of the dominance of the science identity over the science teacher identity is an understanding of the importance of group membership. Two of the three participants described themselves as 'science people' and did not identify that they wanted to become teachers until the end of the science degree. Therefore, it is perhaps unsurprising that they had not, over the course of a training year, yet developed science teacher identities through group membership that superseded well-established science identities.

Hong et al. (2017) drew on the dialogical self-theory of Akkerman and Meijers (2011) to explore the development of high school science teacher identity in five individuals during a four-year study, beginning at the preservice year until the end of their third year of teaching post-qualification. Hong et al. (2017) identified three themes from Akkerman and Meijers (2011): (1) multiplicity and unity - multiple identities held with a common thread; (2) social and individual - the role that the social context plays in the formation of individual identity; and (3) discontinuity and continuity - change over time. In contrast to Day (2006), where the focus of personal, situated and professional identities is broadly on the end-product of 
identity (e.g. mother, Head of Department, outstanding inquiry teacher), Hong et al.'s (2017) themes overtly focused on the contrasts within different aspects of identity. Hong et al. (2017) argued that the distinction between professional and personal identity is a false one, and that teacher identity development would be better understood without the separation of identity facets into these two broad groups and with a greater understanding of the importance of a supportive social environment. This understanding of the value of a supportive social environment is consistent with other research studies considered in this group (e.g. Manning, 2017; Richardson, 2019), although the importance of the social environment is not always given the same weight. The interaction between two other aspects of identity: science/subject identity and teaching identity is considered in the following section.

\section{The importance of science/subject identity compared to teaching identity}

Seven publications featured discussions of the relative importance of identities related to an individual's science/subject identity versus their teaching identity, with studies considering both preservice (Chung-Parsons \& Bailey, 2019; Irving-Bell, 2018; Nieswandt et al., 2013; Ortega et al., 2015) and qualified (Beijaard et al., 2000; El Nagdi et al., 2018; Manning, 2017) high school science teachers. In a study that analysed survey responses from 80 teachers, 27 of whom taught science and mathematics, Beijaard et al. (2000) showed that teachers saw their identities as more closely aligned to their subject rather than as pedagogical experts and that this was especially true for teachers at the beginning of their career, for science and mathematics teachers, and for male teachers. This finding of the importance of science/subject identity over teaching identity in a study from the Netherlands that is nearly 20 years old is consistent with more recent research from a range of locations including the UK (Irving-Bell, 2018; Woolhouse \& Cochrane, 2015) Chile (Ortega et al., 2015), the USA (Chung-Parsons \& Bailey, 2019; El Nagdi et al., 2018) and Canada (Nieswandt et al., 2013). Participants in this diverse group of studies were more likely to define themselves in relation to a shared identity around their subject, and therefore more likely to enact the norms and values associated with that identity than those of a teaching identity.

Relatedly, Irving-Bell (2018) considered how experience-related beliefs shape the formation of teachers' individual identities and found that subject knowledge was a core part of establishing positive professional identities. Woolhouse and Cochrane (2015) highlighted 
the importance of relationships with peers in supporting the development of teachers' identities in relation to the subject they teach, with networks providing a supportive community of practice in which to develop their use of subject and educational language. Research that reported the dominant science/subject identity was conducted with both preservice and qualified high school science teachers. The research of Woolhouse and Cochrane (2015) was undertaken with trainee teachers who participated in a Subject Knowledge Enhancement (SKE) course in physics, chemistry or mathematics as they were training to teach in one of these subjects in high schools, having a pre-existing specialism in a different but related area (e.g. biology, psychology). This may explain why the community of practice was so closely linked to subject identity for this group of trainee teachers. In the main, we suggest that teachers, at the beginning of their careers, have not yet had sufficient time to form identities that are shaped by teacher group membership, and therefore have identities that are predominantly rooted in their subject. This development of teacher identity over time is supported by Manning (2017) who found that urban high school science teachers who had been teaching for an average of five years had group membership that was more strongly aligned with urban school teachers as opposed to science teachers.

Synthesising the literature considered in Group one, we suggest that these studies demonstrate that middle and/or high school science teacher identities are understood as social or community identities, where an individual has an affinity with both science and science teaching. Identities can also be understood as being formed by the interaction between personal context and professional setting. Models and conceptual frameworks that featured in Group one frequently incorporated Gee's (2000) understanding of identity, as that which is socially and culturally constructed by nature, institutions, discourse and affinity. We also note that Avraamidou (2014a) highlighted a need for greater understanding of the ways in which different contexts shape and influence identity development. We argue that the SIA provides a new way in which to understand both how different aspects of identity interact both with each other and in different spaces and settings. For example, rather than understanding the concept of 'affinity' identity as shared practices between group members, the SIA both extends this concept to include shared identity and provides insights into the ways in which groups are formed, reformed and maintained through the concepts of identification, ideation, interaction, influence and ideology. An analysis of changes and movement in affinity identities as observed by Hsu et al. (2017) that is guided by the SIA might view this as the development of multiple group memberships (e.g. learner, teacher) and with the 
understanding that having more than one source of professional identity is to be encouraged as this might help preservice teachers (and those who are involved in their education and training) to better understand the value of these concurrent identities, rather than viewing one as subsidiary or in transition to another.

\section{Group two: Studies that focus on a specific aspect of a middle and/or high school science teacher's own context or experience}

Studies identified in Group two broadly considered prior experiences of identity formation and were synthesised into two sub-groups, where the focus of research into middle and/or high school science teachers considered (1) the experiences of teachers working in contrasting and diverse cultural contexts and (2) those teachers who had been or were going through the process of changing careers through teacher training. Although these sub-groups were not entirely mutually exclusive (for example, there were a diversity of cultural contexts for those moving from a pre-existing career into teaching), the process of career transition provided a more focused lens through which to consider changes in culture than did the broader experiences explored within the first sub-group.

\section{Contrasting and diverse cultural contexts}

Twelve publications that included an exploration of the cultural contexts that teachers draw on when developing their professional identity focused on preservice teachers as well as life histories and narratives from qualified teachers (Table 4). Ritchie (2009) and Harrison (2018) contributed broader theoretical discussions of identity in socio-cultural contexts (Table 4). Perhaps unsurprisingly, these twelve publications incorporated research from a diverse range of countries and cultural contexts. Research based in the USA included African-American, Asian-American and Rural Appalachian perspectives (Brand \& Glasson, 2004; Moore, 2008) as well as immigrant or non-dominant ethnic groups (Blackwell, 2012; Kitonga, 2011; Rivera Maulucci, 2008; Seiler, 2011). Researchers also considered the cultural contexts of Maori (Edwards \& Edwards, 2017) and native Hawaiian (Allaire, 2013; Fitzgerald, 2018) teachers. UK-based research has considered the experiences of a UK teacher working in diverse contexts (including ones that are different to those with which they are more familiar), including Sierra Leone and Bhutan (Childs, 2018). This qualitative body of research used a range of approaches including personal histories and narrative inquiry, in detailed, rich work with small numbers of participants. Drawing on this literature we identify a core theme, 
namely, that teachers working in contexts which include a plurality of cultural perspectives often develop multiple shared identities.

Research which explored the life histories and personal narratives of high school science teachers working in Hawaii, including native (Allaire, 2013; Fitzgerald, 2018) and non-native (Fitzgerald, 2018) Hawaiians, highlighted the importance of a pluralistic understanding of identity. Allaire (2013) found in his study of native Hawaiians that their identity was formed as a mosaic, with separated but interconnected parts that make up a whole, and which drew on personal and professional sources. This plurality of identity is also found in a study of African-American, Asian-American and Rural Appalachian science teachers working in American urban high schools that contrasted with their previous experiences (Brand \& Glasson, 2004). In research over a five-year period with six teachers, Fitzgerald (2018) found that both non-native and native Hawaiian teachers who taught high school science in Hawaii developed facets of their professional identity which included ecological awareness and a desire to share an inherent love of nature with their students, which Fitzgerald (2018) described as 'eco-identity'. At the same time, three teachers (including native and non-native Hawaiians) retained an approach to teaching that was more consistent with an anthropocentric focus on attaining qualifications and progressing into STEM careers. This suggests that cultural influences on identity development are complex and that those teachers who themselves have multiple professional identities, or who recognise that pluralism in their colleagues, work to find balance and a bridge between these different experiences and influences (Fitzgerald, 2018).

Seiler (2011) also considered the place of western science teaching narratives in the USA where, although high school science classrooms in urban areas are more ethnically, racially and linguistically diverse, science teaching remains predominantly aligned to white, western norms where western (Europe, North America, Australia and New Zealand) traditions of science knowledge and practice are seen as more valuable than sources of indigenous science knowledge. Seiler (2011) drew on three cases studies of AfricanAmerican teachers to consider how their science identities were formed. Seiler (2011) suggested that the science identities of those from non-dominant groups were frequently formed outside of school settings (e.g. baking in the kitchen and life on a rural farm), where their identities as active 'science people' did not conflict with the prevailing norms of white, western science they experience in the school classroom. This demonstrates the importance of considering science identities and contexts and of teachers not disseminating science solely 
through western norms. Kitonga (2011) supports this perspective, documenting the pedagogical and cultural tensions experienced by two immigrant science teachers from Nigeria and Kenya working in US high schools. Kitonga (2011) suggested that science classrooms became richer spaces of thought when there is a dialogue between contrasting sources of science knowledge from western and indigenous perspectives and that this dialogue provided further ways of thinking about the place of science in students' lives. Rivera Maulucci (2008) also found that immigrant science teachers faced challenges (e.g. language) where predominantly western norms privilege western science and limit other perspectives. Harrison (2018) considered the experiences of teachers who encountered contrasting socio-cultural contexts, sometimes called 'boundary crossing', and argues that these experiences can generate but also impair professional growth. Harrison (2018) drew attention to the high and varied demands faced by inexperienced and preservice teachers and suggested that incorporating professional experiences that are socio-culturally divergent as part of a trainee or newly qualified science teacher's development risks lowering teacher selfefficacy and limiting professional growth.

Blackwell (2012) and Moore (2008) explored the positional identity (which has been defined by Holland et al. (1998 p.132) as 'a sense of relative social position') of science teachers working in the USA. Blackwell (2012) found that teachers who struggled most with finding agency within their positional identities were immigrants who were not able successfully to align their personal, cultural identities with their professional, socially determined teaching identities. Similarly, Edwards and Edwards (2017) suggested that for those teachers for whom cultural identity and indigenous knowledge is important, identity development can be a more complex process that requires time and space to reflect, especially during the training year - although this may also be true for teachers throughout their careers. In research that explored the positional identity and development of three African-American science teachers, Moore (2008) suggested that positional identity needs to be understood in a way that moves beyond broad socio-cultural contexts, arguing that in a study of three high school science teachers from very similar backgrounds, positional identity was shaped by three very different things: (1) meanings of their life experiences; (2) orientations to professional development; and (3) future career goals in science education. Again, this body of research points to the additional challenge faced by groups who are not entirely situated within the western norms of science. Drawing on the SIA that recognises the importance of multiple, positive and complimentary identities, we would argue for 
understandings of science and science teaching that more readily incorporate the contributions of thought and knowledge from non-western cultures and include greater acknowledgement of the contributions to scientific discovery and understanding made in nonwestern societies.

Rarer studies considered the experiences of western teachers working in contexts that were very different to their own. Childs (2018) shared her experiences as a UK citizen and UK-trained teacher working in Sierra Leone and Bhutan and identified the importance of support from colleagues that was required for her be effective in working in these new spaces. Here, social mechanisms are required to support the integration of a teacher working in a context that is different from their own, and SIA recognises this through the concept of interaction, where shared group membership brings individuals within this group support, and agency. Ritchie (2009) argued that some interpretations of science teacher development, including the consideration of an elementary science teacher's identity by Upadhyay (2009), were made too quickly to validly establish shifts in identity. Instead, Ritchie (2009) argued, researchers could more helpfully understand identity as comprised of multiple roles, with different roles contributing to an individual's identity or sub-identity depending on the context. We suggest that Ritchie's (2009) understanding is consistent with the concept of multi-faceted identities found within the SIA approach. Ritchie (2009) also argued that researchers studying teacher identity should include more detailed narrative accounts from teachers and that teachers should be involved as both co-researchers and co-authors if identity development is to be coherently understood. It seems that teachers from diverse cultural contexts have and develop multiple identities, which represent opportunities for greater psychological resources. These are only possible when the norms of science and of science identity are extended beyond a predominant understanding and incorporate and acknowledge the value of other sources of understanding (e.g. indigenous knowledges).

\section{Teachers who are career changers}

Studies that have considered the experiences of teachers who have transitioned into teaching from a previous career in a STEM-field included two that focused on qualified high school science teachers working in the USA (Antnik-Meyer \& Brown, 2017; Snyder, Oliveira \& Paska, 2013), and four that explored the experiences of career changers during a one-year training course for preservice high school science teachers in the USA (Grier \& Johnston, 2009), Sweden (Molander \& Hamza, 2018), Australia (Watters \& Diezmann, 2011) and the 
UK (Wilson \& Deaney, 2010). All six studies shared findings derived from in-depth, qualitative research with participant numbers ranging from a single individual (Wilson $\&$ Deaney, 2010) to a group of 14 individuals (Watters \& Diezmann, 2011). Understanding the experiences of high school science teachers who are career changers was regarded as important in these studies, due to an increasing number of recruitment strategies and training schemes which directly target career changes, in an attempt to address the international shortage of specialist science teachers. Broadly speaking, the focus of the six studies included in this aspect of the review is around the transition of professional identities from those rooted in a STEM career to that of a high school science teacher and the particular challenges and opportunities this transition represents to the individuals concerned as well as to initial teacher education (ITE) providers. In seeking to theorise this transition, the six studies included a range of theories and frameworks including: identity (Antnik-Meyer \& Brown, 2017; Grier \& Johnston, 2009; Molander \& Hamza, 2018); self-determination theory (SDT) (Watters \& Diezmann, 2011) and transformative learning theory (TLT) (Snyder et al., 2013). Wilson and Deaney (2010) incorporated the concept of identity and self-verification theory and argued for both the individual and social construction of self-concept, briefly drawing on the work of Tajfel and Turner (1986) to emphasise the importance of group membership in developing individual identity (Wilson \& Deaney, 2010, p.172). We offer two distinct but related commentaries on these studies: (1) there is a recognition across all six studies that career changers benefit from ITE that is the same as or broadly similar to ITE aimed at those following more traditional post-graduate routes; and (2) career changers frequently have multiple sources of identity on which to draw; these studies tend to present these changes as transitions into and out of different identity states (e.g. scientist, parent, teacher), rather than understanding these transitions as individuals developing a range of group memberships.

A consistent, but perhaps unsurprising, finding across these six studies that considered career changes is the importance of teacher education courses as a site of intersection between identities of scientist and science teacher. Molander and Hamza (2018) and Snyder et al. (2013) suggested that the transition into teaching from a STEM career lead to the emergence of a new sense of self that is not always compatible with previous STEM identities and, during this transition, ITE courses can provide important spaces that support individuals to reconcile different aspects of identity. Grier and Johnston $(2009$, p.73) argued this further and suggested that ITE programs are an 'essential' part of the process of identity formation of science teachers from any route or background. Part of the acknowledged value 
of ITE is the opportunity for explicit teaching on identity formation to support novice teachers in developing an awareness of their changing sense of identity (Wilson \& Deaney, 2010). Researchers have documented how ITE can acknowledge and leverage STEM career contexts when supporting individuals through this period of transition (Molander \& Hamza, 2018) and provide opportunities for career changers to become reflective practitioners (Grier \& Johnston, 2009), although Wilson and Deaney (2010) suggested that teaching on identity formation should be embedded in ITE. Not all studies have found that ITE courses are effective in meeting the particular needs of mature career changers training to be teachers. Watters and Diezmann (2015) argued that ITE courses need to be more adept at recognising and valuing the prior experience of this group of trainee teachers. Watters and Diezmann (2015) also highlighted the importance of the school context for career changers as a site of professional identity formation. It should be noted that this body of research on career changers emanates from researchers who are also intrinsically linked to developing and delivering teacher education programmes, some of which may include their research participants (Molander \& Hamza, 2018; Snyder et al., 2013; Wilson \& Deaney, 2010). Although research that includes student teachers as participants is not uncommon, it should be acknowledged that studies that are based on very small participant numbers and are drawn from the researcher's own context, which may limit the replicability of findings across broader contexts.

Across the research we considered that is focused on career changers, there is a wellestablished understanding that teachers who enter the profession with experience from the field of STEM have multiple sources of identity that they draw on, depending on the phase or context of training. These multiple identities have been acknowledged as a strength, in that they provide career changers with resources to draw on (e.g. flexibility and resilience through periods of challenge), but can also present challenges, including tension and conflict between competing identities; Antnik-Meyer and Brown (2017) highlighted the need to hold scientist and teacher identities in balance and suggested that this was often achieved over time.

In synthesising the literature reviewed that considers middle and/or high school science teachers' contrasting and diverse cultural contexts we highlight three issues: (1) such teachers who work in contrasting and diverse contexts frequently develop multiple, shared identities and the cultural influence will shape individuals' identities differently; (2) these pluralistic identities are made from diverse and not always complementary sources; and (3) diverse and contrasting cultural contexts can promote or impair an individual's professional 
growth. The SIA helps us understand how diverse and contrasting cultural contexts shape, in the focus of this review, the professional identities of middle and/or high schools science teachers. For example, for teachers who work in cultural contexts that are new to them, such as a UK-trained science teacher taking a teaching role in Sierra Leone as in the case of Childs (2018), or a Nigerian science teacher working in an American high school as described by Kitonga (2011), the process of identification is initially very challenging as their group membership and shared identity with fellow teachers, school students and the wider school community is likely to be far less secure than it was in the contexts from which they recently arrived. When identification between individuals is reduced, so too are the benefits that group membership and shared identity bring to personal and professional identities. By promoting activities and opportunities for interaction (e.g. learning to speak the local language), teachers working in new cultural settings can increase their capacity for identification with their new context. This concept of identification also helps us understand why, for example, science teachers who draw on different cultural sources (e.g. indigenous knowledge) do not always develop positive and strong professional identities when the prevailing western norms of science education do not view their ways of knowing as valuable. This is because in the SIA, identification with a given social identity is only as successful as the extent to which both the individual and the group recognise, acknowledge and affirm membership of the group. So, for a science teacher working in an American high school who draws on sources of knowledge and/or cultural contexts that are seen as less valuable, their membership of the 'American high school science teacher' group may be compromised because other teachers and/or school students do not recognise them as valid members of that group.

Through our synthesis of the literature that considers career changers, we suggest that rather than understanding the changes in identity observed and described in the literature reviewed as transitions from, and into, different identity states or roles (e.g. researcher, scientist, science teacher), researchers might consider the ways in which the SIA makes sense of the observations made in this area. Specifically, we argue that the SIA allows an understanding of these changes in identity as both individuals developing a range of group memberships and the interaction between these different shared identities. For example, rather than an engineer who retrains as a high school physics teacher moving back and forward through phases of identity transition, the SIA approach views this as an individual having shared identities as an engineer and, at the same time, as a preservice physics teacher - and that these shared identities interact. This understanding of interacting group 
memberships highlights the value and importance of enabling teachers to develop a range of broadly compatible group memberships which can provide them with greater resources that are beneficial for their sense of professional self. This understanding of multiple and simultaneous group membership is only acknowledged in a limited way in the career changer literature to date (e.g. Wilson \& Deaney, 2010). We argue that an explicit understanding that career changers are likely to hold multiple, interacting group memberships and that, with support, these multiple sources of identity can be beneficial could helpfully inform both ITE and CPD provision because this understanding moves the focus away from shifting an individual from one state to another but instead explicitly looks to maintain previous professional identities as a grounding for strong future ones.

\section{Group three: Studies that focus on an aspect of the school and/or teaching context for}

\section{middle and/or high school science teachers}

Ten publications included in Group three that broadly considered the teaching context of middle and/or high school science teachers were synthesised into three sub-groups that included a focus on: (1) the school as a field or context of identity development; (2) the development of teachers' identity as teachers of inquiry; and (3) the development of teachers' professional identity in the context of implementing environmental curricula (Table 4). Although these groups do contain boundaries which are porous (for example, teachers of inquiry may also implement environmental curricula), the synthesis of research within these three sub-groups reflects the way the authors of each study identified their work. The third sub-group focuses on environmental curricula because this was the stated context for this set of researchers to explore identity development in middle and high school science teachers. Research in this group is all published in English and undertaken in the USA (Bang \& Luft, 2016; Dreon, 2011; Drewes, 2018; Eick \& Reed, 2002; Enyedy et al., 2005), Canada (Melville et al., 2013; Pedretti et al., 2008) and Australia (Melville et al., 2007).

\section{The school as a field or context of identity development}

Drawing on the work of the French sociologist, Pierre Bourdieu, to explore the social space or 'field' of a school science department, Melville et al. (2007) examined the relationships between ten experienced science teachers, almost all of whom had been teaching together for at least five years in the same Australian high school. Melville et al. (2007) argued that this approach helps elucidate the ways in which individuals identify as science teachers, drawing on personal and professional aspects developed in the social, interactive context of a science 
department. We argue that this conceptualisation of a science department as a distinct space or 'field' is helpful as it delineates the physical and ideological context for shared group membership. Teachers in this department shared professional identities as science department colleagues as well as science teachers in a way that would be recognised within the SIA through the concept of influence - where identity is shaped by the behaviour of group members, especially those understood as group leaders, in this case perhaps the head of the school science department. Webb (2012) explored the identity formation of four first-year high school science teachers and considered how their experiences of induction and classroom science teaching developed their normative science teacher identities. Webb (2012) found that through induction programmes, beginning science teachers developed identities that were more focused on school and school district policies and procedures compared to other aspects of science teaching, for example, inquiry-based instruction. This finding is consistent with a wider body of research (Luft 2009; Luft et al., 2011; Luft \& Zhang, 2014) that has explored the experiences of science teachers in different induction programmes. Apart from Bang and Luft (2016) (see below), we did not include this literature in our systematic review (Table 1) because, unlike Webb (2012), the authors of the research did not include identity as a lens or core concept. We argue that Webb's (2012) understanding of normative science teacher identities can be understood through the SIA as part of ideation, where group norms that are both descriptive ('what we do') and injunctive ('what we should do') shape behaviour. When people identify themselves as part of a group, they will enact the values and behavioural norms ascribed to that shared identity. Webb (2012) and the wider research literature (e.g. Luft, 2009; Luft \& Zhang, 2014) have highlighted the importance of shared group membership for science teachers' well-being, with the close proximity of science specialists and school cultures found to be an important part of promoting beginning science teachers' well-being. This is core to the SIA, where social identity is central to positive personal and professional identity.

\section{Teachers of inquiry}

Studies that considered teachers' identity in the context of inquiry-based teaching approaches were focused on preservice middle and high school science teachers (Dreon, 2011; Eick \& Reed, 2002; Melville et al., 2013). Bryce et al. (2016) argued that professional development opportunities that promote inquiry-oriented teaching predominantly consider teaching practices rather than identity development. Bryce et al. (2016) called on the argument of 
Deneroff (2016) who highlighted the importance of including opportunities for reflexive transformation within professional development programmes. Methods and tools to promote such transformation in teachers included coaching, professional dialogues and online communities (Bryce et al., 2016), and we suggest that the importance of communities (both offline and online) underlines the value of group membership. Eick and Reed (2002) included the theoretical framework of personal histories to understand the development of preservice high school science teachers' identities and how this influenced their ability to implement structured inquiry during their student teacher placement. Those teachers who identified themselves as 'constructors of knowledge' were more able to enact structured inquiry successfully than were those who saw themselves as 'traditional learners' who, through their student placements, were in receipt of knowledge about how to become teachers rather than contributing to knowledge or furthering understanding. Dreon (2011) observed that preservice middle and high school science teachers who enacted inquiry pedagogy experienced emotions, of which anxiety was the predominant one observed. Feelings of anxiety arose in part, from the level of their subject matter confidence when delivering inquiry lessons, that preservice teachers found were frequently unpredictable. Preservice teachers' professional identities were also shaped by their interactions with their students and colleagues, and their perceived agency within the context of their schools' curricula and governance. Taken together, Dreon (2011) and Eick and Reed (2002) suggest that selfefficacy in subject content and teachers' own education experiences are all part of what enabled beginning teachers to develop identities as teachers of inquiry. We suggest that these experiences and beliefs can be understood as part of the SIA, where teachers' ideation and ideologies inform their identity alongside shared interaction (e.g. with students and colleagues).

Melville et al. (2013) argued for the importance of scaffolding (i.e. where the learner gradually takes greater responsibility for learning with the diminishing direction of an expert) inquiry as an approach to teaching and learning to ensure preservice teachers appreciated the value of inquiry as a classroom strategy. When read in the context of Dreon (2011), this scaffolded approach could provide preservice teachers with the necessary support to engage in demanding professional activities, whilst reducing their anxiety. Melville et al. (2013) suggested that teachers should be actively engaged in constructing dual professional identities, both as students of science and as preservice teachers of science so that they have a robust framework when working within two unfamiliar contexts. Consistent with similar 
research studies, Melville et al. (2013) highlighted the importance of teachers' personal experiences (Eick \& Reed, 2002) and emotions (Dreon, 2011) in constituting their own professional identities. In a two-year study of 14 early career US-based high school science teachers, Bang and Luft (2016) highlighted the importance of the school community in shaping beginning teachers' identities, and specifically in the context of inquiry-based teaching. We argue that how teachers are socially positioned directly relates to their ability to integrate into school settings and to how they develop their teaching identities. For example, teachers whose identity is positioned as a 'learner-of-being-a-teacher' have far greater opportunities to explore multiple identities, whereas teachers who are aligned as people who deliver a prescribed curriculum are less able to explore different pedagogical, intellectual, cultural and political spaces that contribute to the formation of a range of identities.

Consistent with Bryce et al. (2016), Bang and Luft (2016) showed how online subjectspecific mentoring provided science teachers with additional online and offline communities in which to develop agency in their role as teachers of inquiry learning. Common to these studies is a recognition that what teachers identify with (ideation) is important and can be shaped by their personal histories as well as their interactions with students and colleagues, both virtually and in person. A gap in the literature is the consideration of the identity formation of teachers who are experienced in inquiry, as the studies considered here are with preservice teachers or those in their first year of teaching post-qualification. Rushton and Reiss (2019) considered the identity formation of both experienced and early career teachers who supported their students in inquiry-based, authentic learning over an extended period. Rushton and Reiss (2019) found that teachers with varying amounts of classroom experience developed positive, multifaceted professional identities. However, more research is needed with experienced teachers working in the context of inquiry learning to understand more fully how this teaching and learning approach shapes identity construction.

\section{Teaching environmental curricula}

As with Eick and Reed (2002), Drewes (2018) drew on teachers' lived experiences when exploring how 15 science teachers' identities developed in the context of working as teachers of climate change in urban, suburban and rural USA. Drewes (2018) observed that teachers' lived experiences shaped their identity development through different trends; this led to four possible constructions of multifaceted, yet cohesive identities: 'Passionate Environmentalist', 'Student Interest Engager', 'Content First Educator' and ‘Civic \& Epistemic Skills 
Promoter'. When developing and enacting these identities, teachers did experience tension and relied upon their instructional agency to overcome periods of challenge (Drewes, 2018). These period of tension were also found in the US-based research of Pedretti et al. (2008), who studied the responses of 64 preservice high school science teachers to teaching global warming, and investigated how identity played a role in their incorporation of STSE (science technology, society and environment education) approaches. At the outset, teachers were confident and motivated to teach STSE, but having participated in the project they reported they were less likely to adopt these approaches in the early years of their teaching. Pedretti et al. (2008) found that this was due to five areas of tension that teachers experienced, which were related to: control and autonomy; support and belonging; expertise and negotiating curricula; politicisation; and biases and ideological foci. Pedretti et al. (2008) argued that these tensions are due to preservice teachers' identities being in a nascent state, where it is challenging to teach science using STSE that is perceived as different from 'normal' practice, and this is consistent with Drewes' (2018) observation of competing tensions when teachers are enacting roles as climate change educators.

We argue that the movement of preservice teachers away from STSE approaches, and the competing tensions observed by Drewes (2018), can be understood through the concept of identification, where when people experience a challenge or threat to their identity they are motivated to maintain it by moving towards more positive sources of shared identity and enacting the norms associated with those more positive sources. In this context, teachers moved towards what they perceived to be 'normal practice' when they experienced tension. Environmental science curricula frequently involve the teaching of dilemmas and complex topics, and Enyedy et al. (2005) argued that teachers' identities were particularly likely to inform teachers' practice when implementing this part of the curriculum. In a qualitative study of two qualified high school science teachers during the implementation of a new environmental science curriculum, Enyedy et al. (2005) showed that teachers draw on multiple sources of identity and that if they are successfully to adapt during a period of professional challenge and change, highlighting the importance of teachers' awareness of the concept of identity formation and development and how this links to their practice. This supports the findings of Pedretti et al. (2008) and Drewes (2018), and is also consistent with wider findings that have shown that at the beginning of middle and/or high school science teachers' careers their subject identity is very strong and it is only over time that their identity 
as a teacher develops (Beijaard et al., 2000; Chung-Parsons \& Bailey, 2019; El Nagdi et al., 2018 Irving-Bell, 2018; Nieswandt, et al., 2013; Ortega et al., 2015).

In our synthesis of literature reviewed as part of Group three, we recognise that the concepts of influence and ideation from the SIA provide an alternative way to understand middle and/or high school science teacher identity formation, specifically within literatures that explore the role of a school science department as a site for identity development and those that consider the experiences of teachers of inquiry or environmental curricula. For example, the concept of influence highlights that when, and to the extent that, people define themselves in terms of social identity, they will be more likely to influence each other (Haslam et al., 2018). Furthermore, individuals, for example leaders, will have more influence in defining the meaning of a certain social identity to the extent that they are seen by others as representative of that identity (Haslam et al., 2018). In this way, influence is a helpful concept when exploring how spaces such as a school science department shape teacher identity, as it allows an understanding of how and why some teachers see their identity as representative of the shared department identity and therefore successfully integrate into a professional setting when others may not. In the SIA, the concept of ideation highlights that what people identity with is as important as having shared identities. In the case of teachers of inquiry and new curricula, understanding what makes up these specific contexts (when considering environmental curricula this could be described as a proenvironmental identity), and therefore understanding what the source of ideation is, enables a better understanding of the conditions required to support a teacher working in these ways.

\section{Group four: Studies that explore the role of alternative training programmes for middle and/or high school science teachers}

Fifteen publications explored the identity development of middle and/or high school science teachers in the context of alternative training programmes (Table 4). Three broad themes were identified: (1) studies that broadly explore the role of alternative training programmes; (2) studies that consider the role of informal science institutions in science teacher training; and (3) training programmes that were explicitly and predominantly framed around reformminded and/or social justice approaches. Research in this group was undertaken in the USA, apart from McIntyre and Hobson (2016), which took place in the UK.

Part of the growth in alternative training programmes has been in an attempt to ameliorate teacher shortages that are particularly felt in mathematics and science subjects 
(Friedrichsen et al., 2008; West, 2015). In the USA, the traditional teaching training route is through a four-year undergraduate degree, whereas alternative certification programs (ACPs) are usually a much shorter (9-18 month) course that is completed by individuals with a Batchelor's degree in a science or related subject and, consequently, participants are drawn from more diverse backgrounds, with a greater range of non-teaching experiences (Friedrichsen et al., 2008). In research that explored the identities of 19 preservice high school science and mathematics teachers who participated in an ACP, Friedrichsen et al. (2008) observed that participants began the program with a range of identities, including participants who firmly identified as teachers as well as those who were exploring teaching as part of wider career development. Consistent with other research (Bang \& Luft, 2016; Dreon, 2011; Melville et al., 2013; Rushton \& Reiss, 2019), participants drew upon multiple sources of identity, including those that complemented their teaching identity (e.g. parent, tutor) and those which created tension.

In a similar study of a different ACP, West (2015) found that the networks that preservice teachers developed with their peers through the alternative teacher training program provided teachers with a community of support that continued during at the least the first year of teaching. Preservice teachers training in the alternative routes described in the research of Friedrichsen et al. (2008), West (2015) and Proweller and Mitchener (2004), enrolled in programs that were designed to address the lack of specialist mathematics and science teachers that is particularly acutely felt in economically poor areas of rural (West, 2015) and urban regions (Proweller \& Mitchener, 2004) of the USA. Although these studies are all based in the USA, the shortages they seek to address are applicable across the UK and continental Europe. Indeed, as indicated earlier in this review, Woolhouse and Cochrane (2015) considered the role of similar provision in the UK (courses called Subject Knowledge Enhancers or SKEs) in shaping trainee teachers' identity. We propose that these alternative teaching programmes are a source of ideation, where participants in these alternative routes share an identity of training to be teachers, in the context of making a wider contribution to society, by seeking to be part of the solution to teacher shortages in science and mathematics. The explicitly social justice element of some alternative training programmes is also a source of ideology (e.g. a desire to increase equitable access to science education for all) which provides the context for both ideation and interaction. Relatedly, West (2015) also indicated that interaction was an important part of developing shared identities that are formed through mutual identification. 
Adams and Gupta (2017) explored the role of informal science institutions (ISIs) as spaces for trainee high school science teacher education that, first, enabled teachers to develop identities that included student-centred approaches where teachers are responsive to the needs of learners and secondly and, relatedly, as spaces that supported the imagination of future professional selves and classrooms that maintain these identities. Considering the research of Adams and Gutpa (2017) in the context of SIA, we argue that ISIs can be seen as a source of ideology, a different context within the wider education system for teachers to develop identification, ideation and interaction. Heredia and Yu (2017) also found that ISIs provided novice high school science teachers with subject-specific support and expertise that was rooted in a community of practice of 'like-minded' science teachers. Subject-specific guidance was recognised by McIntyre and Hobson (2016) as an important source of identity development for beginning teachers of physics based in the UK; however, in this research, subject-specific support was provided by external mentors rather than ISIs. McIntyre and Hobson (2016) suggested that external mentors (experienced subject-specialist teachers working at different schools to their mentees) provided a space where mentees could discuss their professional learning and development needs and could, with the mentors' support, identify alternatives to performative norms. Eick (2009) explored the role of Individual Recommendation Plans (IRPs) in the identity formation of two preservice high school science teachers with contrasting personal histories. This research showed that whilst these plans were a useful tool in supporting the participants to meet the required professional standards and enact their preferred pedagogies, the classroom context (amount of freedom in planning and practice; support from mentor) was the crucial factor in teachers' identity development. As with ISIs (Adams \& Gupta, 2017; Heredia \& Yu, 2017), we argue that mentoring relationships (McIntyre \& Hobson, 2016) and classroom contexts (Eick, 2009) provide alternative sources of ideology which enables different sources of identification, ideation and interaction.

\section{Social justice and reform-minded approaches to teacher training}

Eight publications considered the context of preservice teaching training that was explicitly set within a framework of social justice (Ibourk, 2015; Luehmann, 2007; Luehmann, 2016; Marco-Bujosa et al., 2019; Richmond, 2016; Rivera Maulucci, 2013; Rivera Maulucci \& Fann, 2016) or reform-minded approaches (Danielowich, 2012). Luehmann (2016) described 
reform-based science teaching for social justice as a pedagogy which actively works towards social equity, in the context of more accurate and critical understandings of science for all students, especially those already less well-served by the education sector. In research undertaken by Danielowich (2012), reform-minded approaches were focused upon scienceliteracy reforms, including the nature of science (NOS) and scientific inquiry, rather than reforms that were more closely aligned with social justice. Danielowich (2012) explored the development of reform-minded ideas in six preservice high school science teachers through their individual reflections. These reflections showed five different lenses (lesson format, assessment, classroom climate, lesson content, lesson coordination) that teachers used to negotiate changes in their teaching practices and the dissonances they experienced when enacting these subject-related reforms. Danielowich (2012) suggested that these dissonances could provide a prompt for preservice teachers to orientate their identities as reform-minded teachers and, with support, preservice high school science teachers could consider how their enactment of reform-minded approaches were visible expressions of their identities.

Ibourk (2015) considered the identity formation of three preservice high school science teachers participating in a scholarship program which included working in a highneeds urban school based in the USA. These preservice teachers identified specific challenges they faced (e.g. limited learning resources and different abilities) and how they overcame feelings of being an 'outsider' and the perception that they were not valued members of the classroom (Ibourk, 2015). The two teachers who were able to incorporate their own storied identities of science learning into their classroom practice and teaching strategies (e.g. building student relationships) continued to teach in high-needs settings. The teacher who did not identify sufficient coalescence between their storied identities and their teaching strategies did not remain as a teacher. We highlight that, consistent with preservice teachers who enrol in alternative teaching programmes, preservice teachers in high-needs settings are successful at negotiating these complex and challenging contexts when they find they share the ideology of the program, setting, and/or their peers and mentors. This shared ideology underpins a shared social identity that supports preservice teachers to persevere through challenge and ultimately promotes positive social identity.

The importance of shared ideology was also found in Marco-Bujosa et al. (2019), who explored the professional identity development of four novice high school science teachers who participated in a two-year Urban Science Teacher Preparation (USTP) program. The USTP program had a distinct focus on teaching science for social justice and supporting 
participants to identify structural injustices in schools. Marco-Bujosa et al. (2019) found that all four participants negotiated school policies and procedures through a process of identity work to discern the ways in which opportunities for school students to engage effectively in science learning were limited. This identity work occurred through three sequential processes: (1) deconstructing the school context; (2) positioning themselves as individuals within and in opposition to the school context; and (3) enacting their identities. In addition to the importance of providing novice teachers with the ability to critically analyse the systemic and structural inequalities that are inherent in school-based science education (Cochran-Smith et al., 2009), Marco-Bujosa et al. (2019) highlighted the need for sustained support throughout teaching training programmes and initial years working in schools so that teachers could develop the relational and personal dimensions of building professional practice to become socially just science teachers, especially in the context of high-needs urban high school settings. As with the work of Ibourk (2015), Marco-Bujosa et al. (2019) highlighted the importance of a shared ideology; however, we suggest that the research of Marco-Bujosa et al. (2019) also brings to the fore the role of interaction in negotiating relational dimensions of teaching for social justice - enacting and establishing such identities is made possible through a combination of understanding an individual sense of self and how that sense of self is recognised and accepted or contested by others.

In defining social justice teaching approaches as 'an ongoing struggle for more caring, equitable, and agentic schooling at classroom (micro), school (meso), and community/society (macro) levels' (p.454), as with Ibourk (2015) and Marco-Bujosa et al. (2019), Rivera Maulucci (2013) also recognised the structural and procedural inequalities that novice high school science teachers encountered when seeking to enact professional identities that challenged and disrupted inequitable school environments. Drawing on the case study of Nicole, an African-American trainee chemistry teacher, Rivera Maulucci (2013) explored Nicole's emotions and positional identity as documented in qualitative autobiographical accounts of Nicole's development as a socially just high school chemistry teacher. Rivera Maulucci (2013) identified a three-part cycle that Nicole repeatedly moved through during her preservice training: (1) identification - which included identifying unjust systems and experiencing emotions; (2) reflection - where critical dissonance and emotional ambivalence were processed through teacher sense making and positioning; (3) response - which included personal goal setting, enactment of new practices and evaluation. We contend that these three phases can also be understood through the SIA, where Nicole's ideology, that is rooted in her 
own identification as a socially just teacher, shapes her identification, ideation and interaction with the teachers, students and mentors she encountered during this period of training and personal development.

Developing as a socially just teacher is not without difficulty or challenge, and researchers in this field clearly highlighted the emotional ambivalence that individuals faced relating to their personal and professional identities (Richmond, 2016; Rivera Maulucci, 2013; Rivera Maulucci \& Fann, 2016). In an exploration of a ten-year science education program called Get Real! Science (GSR), which had a focus on developing science teachers who are committed to social justice, Luehmann (2016) highlighted the importance of out-ofschool contexts (e.g. after-school science clubs) that provide low-risk settings to explore professional identity development. The need for these non-judgemental spaces, where preservice teachers could explore and reflect upon their emerging identity, is also commented on in McIntyre and Hobson (2016). These 'third spaces' may be situated in physically different settings (e.g. ISIs) or made manifest through alternative professional relationships (e.g. with external mentors). What is common across the use of these spaces is a lack of judgement and the professional freedom to explore and experiment (Adams \& Gupta, 2017; Luehmann, 2016; McIntyre \& Hobson, 2016).

Luehmann (2007) highlighted the emotional challenges that reform-minded teachers faced and the need for periods of reflection in order to undertake the 'repair work' necessary to continue to develop this identity. Luehmann (2007) identified two design principles for reform-minded professional development courses: (1) to scaffold opportunities for science teachers to develop their identities as reform-minded teachers and include safe places to experiment and enact these practices; (2) give recognition and encourage beginning science teachers to recognise their new identities through coaching and guided reflection. Other research that considered the place of identity and emotions in the development of social justice and reform-minded teachers contributed frameworks which could inform the training and continuing professional development of educators (Richmond, 2016; Rivera Maulucci, 2013; Rivera Maulucci \& Fann, 2016). In the context of the continuing science teacher shortage in high-poverty schools in the USA, Richmond (2016) argued that developing teachers' sense of commitment to working in these challenging contexts is crucial for successful recruitment and retention of individuals appropriate for this setting. We suggest that this is a further example of the importance of shared ideology for teachers, particularly when the setting is challenging, where shared identity supports individuals through periods of 
tension and conflict. Richmond (2016) identified three aspects that should be considered when developing teacher preparation programs that are socially just: (1) professional identity; (2) teacher agency; and (3) school context. We argue that these three facets could also be usefully situated as part of the SIA, with a teacher's overarching ideology focused on social justice. As part of this, professional identity could be understood as identification, teacher agency as interaction and influence and school context as a source of ideation. Not only does the SIA bring coherence to a body of research that considers reform-minded and socially just teacher preparation and professional development, the SIA highlights the mechanisms of identification, ideation, interaction, influence and ideology (Haslam, 2017) that promote and enable shared identity and group membership. Whilst the science education literature has recognised that science teacher identities are socially constructed (Avraamidou, 2014a), the mechanisms that enable this have had limited consideration in the field to date.

Understanding both the role of shared group membership in shaping professional identity and the ways this can be developed can help teachers navigate emotionally demanding contexts and this could form part of all teacher education programmes, but particularly those serving contexts which are socio-economically disadvantaged.

\section{Group five: Studies that consider the role of professional development in forming identity for middle and/or high school science teachers}

The ways in which teachers' identities are shaped by professional development programmes have been considered in studies that explored a variety of programmes including reformminded science education, leadership, STEM-based research, science literacy and blogging (Table 4). Studies included in this part of the review were predominantly from the USA but also included research based in Norway (Mehli \& Bungum, 2013), the UK (Rushton \& Reiss, 2019) and Canada (Melville \& Bartley, 2013; Subryan, 2016). As with research considered in our review of Group three, some studies drew on the theoretical framework of identity outlined by Gee (2000).

Continuing professional development programmes have been developed for teachers in countries (e.g. Canada, UK and USA) where student participation in STEM courses and careers is lower than in countries such as India, China and Singapore (Subryan, 2016). These programmes aimed to support teacher identity development as 'change agents' in science education reform (Subryan, 2016). Subryan (2016) explored the ways in which thirteen high school science teachers' participation in these professional development programmes 
reshaped and influenced their identity. Three dimensions of teachers' experience were identified: (1) cognitive development; (2) social interactions; and (3) emotional changes. However, although nine teachers identified changes in their classroom practice, only two reported that they experienced a change in their beliefs. Subryan (2016) suggested that whilst reform-minded science education programmes could influence teachers' professional identity, the vast majority of those who participated had confidence in their previously established identities. We suggest that these predominantly consistent, unchanging identities could be because teachers who participate in elective professional development programmes with a reform focus already have a shared identity with the ideology of the programme. This is consistent with our interpretation of the importance of ideology in the training of reformminded and socially just preservice teachers.

Shared ideology is also found to be important in the research of Rostock (2014), who explored the identity development of three early-career high school mathematics and science teachers who participated in a five-year long teacher fellowship programme. Rostock (2014) found that individual teachers' abilities to negotiate tensions across the competing discourses they encountered was enhanced by the support network provided by their peers in the fellowship programme. We suggest that this is a further example of the importance of both shared ideology and the benefit of group membership. The importance of shared ideology is recognised by studies that have considered the development of science teachers' identities in the context of reform-minded programmes (Melville \& Bartley, 2013; Sakar et al., 2013), including mid-career teachers with at least eight years teaching experience (Guzey \& RingWahlen, 2018). This is consistent with our reading of the SIA approach in the context of reform-minded and/or social justice programmes for preservice teachers (Rivera Maulucci, 2013; Rivera Maulucci \& Fann, 2016; Richmond, 2016). In addition, Melville and Bartley (2013) highlighted how individual teachers may not have the power to 'fully capitalize on their potential influence within the infrastructure of pedagogical science' (p.171). Saka et al. (2013) suggested that teachers' personal dispositions, institutional expectations and resultant conflict in identities inform an individual's ability to negotiate their early years as a teacher and shape their employment choices. Again, we contend that teachers are better able to negotiate challenging contexts, where their identities are emergent and contested, and when they see themselves as part of a group that has a shared ideology and draw strength and support from this source of shared identities.

\section{Continuing professional development focus on leadership programmes}

Rushton, E. A. C. \& Reiss, M. J. (2020) Middle and high school science teacher identity considered through 43 the lens of the social identity approach: a systematic review of the literature. Studies in Science Education. DOI: 10.1080/03057267.2020.1799621. 
Mayo (2016), Hanuscin et al. (2016) and Sinha and Hanuscin (2017) used the lens of leadership to explore high school science teacher identity development. Hanuscin et al. (2016) argued that identity theory can helpfully inform teacher leadership development programs. Teachers needed both explicit teaching to understand identity development and the opportunity for reflective identity work if they were successfully to develop teacher leader identities and practices. Both individual teacher engagement with a leadership program and a supportive school context were required if teachers were to transfer their redefined identity, established as part of a professional development program. Building on the work of Hanuscin et al. (2016), Sinha and Hanuscin (2017) suggested a model of teacher leadership development based upon research with three high school science teachers at different career stages, who participated in a professional development program. The process of leadership development involved a synergy between three areas: (1) teacher leadership views (developed through reflection and role modelling); (2) teacher leadership practices (developed through exposure to new perspectives); and (3) teacher leadership identity (required opportunities to practice leadership) (Sinha \& Hanuscin, 2017). Although the model was consistent across the three case studies, the pathways to leadership development for teachers were shaped by an individual's priorities, previous life experiences and school contexts. In a similar study, Mayo (2016) explored the professional identity of high school science teachers who take on the role of district-based science specialists to examine how their professional identities were affected by this transition. Mayo (2016) suggested that the primary role and functions of science teacher specialists were those associated with teacher support, e.g. curriculum development and coaching. Unlike Sinha and Hanuscin (2017), Mayo (2016) found that across the eleven teachers, it was possible to identify common paths to teacher leadership; however, evolving teacher identity did include negotiating school and district politics and workload management that differed between individuals. In both studies, the specific features of a teacher's context moulded their pathway to leadership and in turn their identity development. Drawing on the SIA, we argue that when teachers move through a process of leadership development, they are potentially shifting their group identification from that of a science teacher to that of a science teacher leader, whilst still retaining a shared identity with the broader group of educators. This shared group membership as an educator enables individuals to develop their identities as teacher leaders whilst participating in a professional development program. However, if their school context does not enable this emergent identity to be embedded, teachers will revert to a strong science teacher identity as 
part of the process of identification. We suggest that identification, rather than ideology, is visible as part of teachers' engagement with leadership programs, since ideology is more closely grounded in issues concerning class, political views, gender, religious faith and race.

\section{ESOL and blogging as a focus of professional development}

Lew (2016) explored the identity development of four in-service high school science teachers who trained to be ESOL (English to Speakers of Other Languages) teachers. Lew (2016) found that whilst teachers were able to articulate and describe the ways their identities had been shaped and extended through participation in this 18-month long programme, they were not able to enact these new identities in the classroom. This was because they struggled to move from a focus on their science identities to those of an ESOL teacher, partly because the classroom context did not change and neither did their workload pressures. In contrast, Whitacre (2015) found that four of the five high school science teachers who participated in a programme focused on science literacy through science communication experienced identity shifts that created a change in their teaching practice. One of the three key themes that emerged was the importance of the professional development community created by the programme, along with the themes of student engagement and the teachers' change conceptualisation of science literacy (Whitacre, 2015). These examples from Lew (2016) and Whitacre (2015) show that professional development programmes can provide a framework through which teachers can consider their identities and develop and shape them. However, once the programme has finished, teachers require changes in their classroom contexts and institutional expectations and support from peers and/or communities of practice if they are to embed new and emergent aspects of their identities beyond the life of the training period.

Hanuscin et al. (2014) and Luehmann (2008) explored the role of blogging as a professional development activity that gave middle and high school science teachers an opportunity to develop their identities. Hanuscin et al. (2014) suggested that blogging provides a safe space for high school science teacher leaders to explore different identities (e.g. as leaders) through sustained reflection and social interaction. Luehmann (2008) also noted the opportunities that blogging brings for both individual reflection and developing communities of practice, where teachers can give and receive feedback and display their competence. However, Luehmann (2008) suggested that the extent to which blogging supports middle school science teacher identity development in this way is dependent on how the individual teachers used this tool. We suggest that blogging could be seen as a third space 
for identity development, where, in common with other research, such a space provides a non-judgemental and open professional environment (Adams \& Gupta, 2017; Luehmann, 2016; McIntyre \& Hobson, 2016). Blogging is also a way of building an online community of practice and a support network, where teachers can establish a shared group identity with other teachers that reaches beyond the geographical confines of their classroom and school. A shared group membership through electronic networks can be particularly important for teachers seeking to develop their identities where they are perhaps the only subject specialist in their school (e.g. high school physics teacher) or when their emergent identities as reformminded teachers create dissonance with colleagues in their institution.

\section{Teacher engagement with science-research as a focus of teacher professional development}

Studies that considered the experiences of high school science teachers who engaged in professional development programmes that are rooted in research-based approaches included Mehli and Bungum (2013), Rushton and Reiss (2019) and Varelas et al. (2005). Mehli and Bungum (2013) identified that science teachers belonged to several communities of practice including teacher, science teacher and scientist, and suggested that the focus of the literature on teachers' professional development is on their role as educators rather than their identity as scientists. This is unsurprising, as research has demonstrated that science teachers, particularly early career teachers, strongly identify with their subject (e.g. Beijaard, 2000; Manning, 2017), and developing an identity as an educator is crucial to be an effective teacher. However, Mehli and Bungum (2013) argued that professional development that is situated in authentic science research contexts gives high school science teachers an opportunity to engage and work with science professionals in a way that provides insights into scientific practice in modern society. These experiences, formed as part of a week-long residential science camp, are beneficial to developing science teachers' subject-specific professional identities (Mehli \& Bungum, 2013). This is consistent with the findings of Rushton and Reiss (2019), who considered the professional identity development of 17 high school science teachers. This group of teachers (with their students), collaborated over at a least a six-month period in authentic science research with scientists, who were based in universities and research-institutes. Rushton and Reiss (2019) described how these teachers, at varying career stages and with a range of prior experience of science research, developed multi-faceted professional identities that enabled them to be both science teachers and 
'teacher scientists'. Rushton and Reiss (2019) argued that the key enabling factor in this identity development was the teachers' positive interaction with scientists and/or researchers.

There are key differences in the genesis and implementation of the professional development programmes considered in the research of Rushton and Reiss (2019) and Mehli and Bungum (2013). For example, in Rushton and Reiss (2019), high school science teachers worked with their students, predominantly in their school environments with the engagement of scientists and/or researchers over an extended period of time (at least six months). In contrast, in the research of Mehli and Bungum (2013), science teachers, gathered from across Norway, and drawn from elementary, middle and high school settings, participated in a weeklong residential course located at a space technology research site. However, even though the models of delivery were distinct, the outcomes were broadly similar: teachers in both programmes developed their identities as both teachers and scientists through engagement with 'real scientists' and 'authentic science' in a way that enhanced their professional identity beyond the initial life of the programme. Varelas et al. (2005) considered the identity development of four beginning high school science teachers who completed a 10-week summer apprenticeship in a science laboratory. Teachers in this study identified features of science as a practice (e.g. theory and data, complexity) and a community of practice (collaboration, autonomy, mentoring) and were positive about the freedom and the community of working in the laboratory space. However, some teachers expressed tension and conflict when bringing their experiences of the apprenticeship to their identities as science teachers, and described difficulty in incorporating their scientist identity into their classroom (Varelas et al., 2005). As with Melville and Bartley (2013) and Saka et al. (2013), the research of Varelas et al. (2005) demonstrates the importance of supportive professional environments (in this case schools, departments and classrooms) and networks (colleagues and senior leaders) if teachers are to successfully transfer nascent facets of their identities from one context to another. We contend that more explicit teaching and learning on identity development, given the importance of shared group membership and multi-faceted professional identities, could enable teachers to capitalise on these development opportunities as a source of long-term career satisfaction and well-being.

We suggest that those middle and/or high school science teachers who participate in elective professional development programmes are likely to already have shared ideation with their chosen programme. Or, to put it another way, they are likely to perceive the goals and aims of the programme as relevant and valuable to their established professional identity. 
For example, those who are strongly motivated to promote more equitable access to, and participation in, science through their role as a high school science teacher or leader are more likely to participate in a programme that is explicitly framed around social justice.

Alternatively, we argue that those who already perceive themselves as part of groups such as subject experts, researchers or scientists are more likely to choose programmes that focus on inquiry and STEM-based research. We contend that understanding ideation as a source of shared identity through the SIA is helpful, as it highlights the efficacy of explicitly sharing and clearly articulating the goals of professional development programmes, especially when they are not grounded in identity work, so that prospective participants are better able to select courses that enhanced their shared identities or enable them to develop more latent or emergent group memberships. We propose that understanding the role of shared identities is also relevant when designing programmes so that teacher educators are better able to consider how professional development settings can provide sources and spaces for shared identity development, especially when this is not an overt part of the core programme. For example, a professional development programme for teachers focused on how they can improve the practical skills of high school biology students may also provide a space for those teachers to develop their identity as a biologist or a teacher of inquiry. This could be achieved through a teacher's shared ideation with the value of providing greater opportunities to implement practical work in their classroom contexts, and through interaction with fellow teachers and those delivering the course who share these values and norms. This could provide both an efficient and an effective way of delivering professional development programmes that promote positive shared identities that are themselves explicitly multi-faceted.

\section{Discussion}

The research considered in this review and focused on the professional identity of middle and/or high school teachers has been synthesised into five key areas (as summarised in Table 4): (1) studies that broadly consider identity development in teachers, using a variety of frameworks and models; (2) studies that focus on a specific aspect of a teacher's own context or experience, such as cultural contexts and career changers; (3) studies that focus on an aspect of the school and/or teaching context, including teaching inquiry and new curricula; (4) studies that consider the role of the training programme, for example those that are based in alternative institutions or situated in reform-minded frameworks; and (5) studies that consider the role of professional development opportunities, including leadership, STEM 
research and blogging. In reading across this body of research we recognise that there continues to be a variety of conceptual frameworks and models used to explore the construct of identity and that these acknowledge the importance of both individual and social elements. The literature frequently underlines how, for middle and/or high school science teachers, their identity is often rooted in both their subject identity and their science community identity and that experiences such as contrasting cultural contexts and new curricula can both promote and impair identity development, depending on the level of support that exists. Research has highlighted that over time and at different career stages, middle and/or high school science teachers draw on multiple sources of identity. These varied sources can support the development of more robust professional identities, but individuals can also experience tension and conflict. These themes are consistent with the themes of social construction and the dynamic and complex nature of identities found by Avraamidou (2014a).

In her review, Avraamidou (2014a) identified limitations of the science teacher identity literature considered in her review. Key areas of weakness in this literature were: (1) the lack of coherent and well-defined conceptualisation of science teacher identity; (2) the disconnect between theoretical frameworks and reform recommendations; and (3) the need to understand how science identities are enacted in the classroom (Avraamidou, 2014a). Methodological weaknesses included a reliance on very small participant numbers, studies that were a year or less in duration and where the context was oblique, and a predominance of qualitative studies (Avraamidou, 2014a). Avraamidou (2014a) contends that large-scale, quantitative studies would draw on a more inclusive and diverse participant group. That is not to say that qualitative studies do not bring substantial insights to understandings of identity. Indeed, their rich, narrative accounts enable reflective and detailed analysis, and both Avraamidou's (2014a) review and our own confirm the valuable contributions that qualitative, narrative and case study approaches have made to this field of research.

We chose to focus our review on science teacher identity in middle and/or high school contexts. This was because we believe the predominantly generalist role that teachers have in the primary (also called elementary) school context (teaching children under 11 years of age) means that their relationship to a subject or discipline (e.g. science, mathematics, English) is often different to that of a middle or high school teacher, who is often a specialist in one subject (even though they may teach subjects in addition to this). The identity development of elementary school science teachers does feature strongly in the science teacher identity literature (e.g. Akerson, Pongsanon, Weiland \& Nargund-Joshi, 2014; Avraamidou, 2014b; 
Danielsson \& Warwick, 2014a\&b; Forbes \& Biggers, 2016; Forbes \& Davis, 2008; Kane \& Varelas, 2016; Katz et al., 2011; Luehmann \& Markowitz, 2007; Settlage, Southerland, Smith \& Ceglie, 2009; Upadhyay, 2009). However, we suggest that further research could fruitfully consider the identity development of non-subject specialist science teachers in both primary and high school contexts and explore the commonalities and differences therein. This focus is also consistent with Avraamidou's (2014a) call for researchers to provide greater insights regarding the contexts of identity development.

Drawing on our findings we argue that in addition to greater clarification regarding context, researchers should seek to incorporate the experiences of science identity development in non-western cultural contexts, where English is not the first language. We recognise that it is a limitation of this current review that we were only able to consider studies published using Latin script, and we recognise that future work should focus on bringing much needed diversity to the published academic literature which is still predominantly focused on studies from the USA. Relatedly, we contend that the literature would benefit from research that pertains to identity development of ethnic minority science teachers in their preservice training and throughout their teaching careers. As Seiler (2011) highlighted, active science identities from non-dominant groups are frequently formed outside of school settings which, unlike their experiences of classrooms, do not conflict with their sense of self. Research that explores the role of out-of-school settings in students' identity development could contribute to further understandings of students' participation in school science and university courses as well as studies that consider public perceptions of science and scientists.

Avraamidou (2014a) suggested five directions for research in science teacher identity: (1) studying science teacher identity as a process; (2) connecting science teacher identity research and reform recommendations; (3) conducting large-scale, longitudinal and lifehistory studies; (4) examining teacher identity enactment in school classrooms; and (5) understanding the role of contexts on identity development. Our review of the literature suggests that some advances have since been made in two of these research directions, namely: (3) conducting large-scale, longitudinal and life-history studies; and (5) understanding the role of contexts of identity development. In all, our review identified five large-scale, quantitative studies that consider science teacher identity using data collected from surveys, each with 100-400 responses (Chi, 2009; Heredia \& Yu, 2017; Mehli \& Bungum, 2013; Nieswandt et al., 2013; Woolhouse \& Cochrane, 2015). The longitudinal 
studies in this review were all published since 2015 (Childs, 2018; Edwards \& Edwards, 2017; Fitzgerald, 2018; Hong et al., 2017). However, life-history and autobiographical studies (Ibourk, 2015; Roth, 2016; Richardson, 2019) are rare. We also found that studies focused on experienced teachers (those with over ten years teaching experience) were less frequent than those focused on preservice and beginning teachers. A life-history or, perhaps, a career-history approach found in Richardson (2019) would enable a consideration of how identity changes over time and develops in different contexts. It would also allow further exploration of identity development in teachers who persevere through periods of career challenge, and elucidation of why some are retained in the profession, and some are not. Some of these themes have been considered in the research included in this review (e.g. Deneroff, 2016; Guzey-Ring \& Whalen, 2018; Manning, 2017; Richardson, 2019) and this research has all been published since 2015, suggesting growth and development in this area of identity research. However, the timeframe for these research projects rarely extend beyond one to five years, and are often conducted during the first five years of a teacher's career (Edwards \& Edwards, 2017; Heredia \& Yu, 2017; Hong et al., 2017; Richmond, 2016).

The fifth future direction for science teacher identity research highlighted by Avraamidou (2014a) is to consider the roles of different contexts on identity development. The study of context has been an area of growth in the literature, with studies exploring: informal science institutions (Adams \& Gupta, 2017); STEM workplaces (Antink-Meyer \& Brown, 2017); online mentoring (Bang \& Luft, 2017); blogging (Hanuscin et al., 2014; Luehmann, 2008); STEM schools (El Nagdi et al., 2018); research sites, e.g. laboratories (Varelas et al., 2005) and space technology research sites (Mehli \& Bungum, 2013); and engagement in authentic science research (Rushton \& Reiss, 2019). Melville et al. (2007) explored science identity development within the context of a school science department through Bourdieu's social space of 'field'. We suggest that further studies of identity within school science departments would enhance our understanding of social interactions and group membership within these professional contexts. Ritchie (2009) argues that researchers should include more opportunities for teachers to co-author research that examines identity development (e.g. Hanuscin et al., 2016). It is our contention that this might be more achievable if studies are situated within school science departments; however, thought needs to be given to possible approaches to teacher co-authorship. Researchers would do well to consider approaches including 'Students as Partners' (SaP), where all those involved in research are, 'in a relationship ... and ... are actively engaged in and stand to gain from the 
process of learning and working together' (Healey, Flint \& Harrington, 2014, p.12). MercerMapstone et al. (2017, p.2) acknowledge the 'range of practices and pedagogies' included in $\mathrm{SaP}$ approaches and identify the common thread as 're-positioning of the roles of students and staff in the learning endeavour, grounded in a values-based ethos'. The SaP could provide a helpful way to support teacher co-authorship and therefore incorporate more of the teachers' voice in research that explores their identity development.

In the relatively short time since Avraamidou's (2014a) review, it is perhaps unsurprising that the number of additions to the other three research areas is quite modest; however, the significant growth in the identity literature, as evidenced by our review, suggests that these areas can and should be considered by researchers. In this review, we have argued that the SIA provides a useful lens through which to view a diverse literature as it underlines the importance of group membership and shared identity in enabling, maintaining and extending positive and robust professional identities and that, through the concepts of identification, ideation, influence, interaction and ideology, the SIA brings new insights as to how and why middle and/or high school science teachers form positive professional identities. In this way, we argue that the SIA extends our knowledge of science teacher identity from recognising identity as something that is socially constructed towards understanding how and why identities are socially formed and re-formed. In the final part of this discussion, we focus on the central contribution that we propose the SIA makes to science teacher identity, namely, that the SIA gives a greater understanding of the importance of groups and group membership to teacher identity and helps us understand how and why these group memberships form. As it is the focus of our review, the research we have drawn on considers middle and/or high school science teachers. However, we contend the arguments we make about group membership are relevant for teachers of other disciplines and are therefore more widely applicable.

\section{Group membership and social identity: understanding the formation of middle and/or high school science teacher identity through the lens of the SIA}

The SIA approach brings to the fore the importance of group life for an individual's health and well-being (Haslam, 2017; Haslam et al., 2018). We argue that understanding the role and place of group membership and social identity in middle and/or high school science teacher identity development is core to providing those individuals with robust and purposeful professional identities. Our review demonstrates that the social context and 
practice of teaching has been acknowledged in the science teacher identity literature, but this coverage is patchy and at times contradictory. For example, one model of identity development explicitly recognises the community and social aspects to identity (Chi, 2009) whilst in another model the social component is only implied (e.g. Garner et al., 2016; Garner \& Kaplan, 2018). Both Chi (2009) and Garner et al. (2016) drew on the work of Gee (2000) who, in identifying 'four ways to view identity' (p.100) provides researchers with a concise conceptualisation of identity as: 'a kind of person' (p.99). In categorising four types of identity, Gee (2000) acknowledged that identity is socially constructed. Indeed, in his description of 'affinity identity', Gee (2000) highlighted that the source of power of this type of identity is experiences shared between 'affinity groups' (p.100). Furthermore, when seeking to describe the concept of identity, Gee (2000) included the phrase 'being recognised as a kind of person' (p.99). This is at the heart of the SIA: who a person is, their identity, is defined by the groups to which they are recognised by themselves, and others, as belonging. Roth's (2016) quotation of Vygotsky's (2005) phrase perhaps best encapsulates this: 'we become ourselves through others' (p.1021). Those researchers that draw on Gee's (2000) concept of 'affinity identity' (e.g. Deneroff, 2016; Hsu et al., 2017; Richardson, 2019) acknowledged science teacher identity as being socially constructed.

What is missing from this body of research is an integrated approach that draws together the individual aspects, or facets, of identity (e.g. personal, professional, situated, affinity, objective, subjective) as well as an understanding of the social processes that form identity (e.g. competition, balance, dissonance) over time. Without this integrated approach, there is a greater likelihood that researchers will be less able to draw insights from across identity-focused research, with its multiple, separate contexts and diverse foci, with the consequence that there would be the potential for learning to be lost. We have argued in this review that the SIA provides both the coherent overview and the nuanced understanding of the process of identity formation and development that the field needs. Common to all studies reviewed is a recognition that identity is both individually and socially informed. For example, research considered in this review has recognised the importance of community (Glass, 2019), context (Childs, 2018; Kitonga, 2011), field (Melville et al., 2007), subject (Beijaard et al., 2000) and social justice (Marco-Bujosa et al., 2019). Whilst all these aspects involve ideas and experiences that go beyond the self, the integral nature of shared identity and group membership has not previously been considered across such a diverse and extensive body of literature and acknowledged as a fundamental part of identity formation 
and re-formation. Absent from research considered in this review is an explicit expression of identification, which lies at the heart of the social identity approach, namely that group membership shapes an individual's behaviour to the extent that their social identity derived from this group membership is incorporated into their sense of self (Haslam, 2017). It is not enough simply to acknowledge that identities are both individually and socially informed; according to the social identity approach, group membership fundamentally alters the way an individual's identity is constructed and developed and, therefore, how they behave. As part of a wider conceptualisation of science identity (as opposed to science teacher identity), Avraamdiou (2019) highlighted the importance of recognition and emotions as core features of identity. Recognition, or how people are recognised by others, Avraamidou (2019) argued, is an 'ineradicable' aspect of the human world and as such requires an understanding of how socio-economic and cultural contexts privilege some identities and diminish and exclude others. We contend that recognition, as part of identification, is a fundamental part of the SIA, where the groups that people identify with are acknowledge and given validity by the recognition of others in a way that shapes their attitudes, beliefs and values and the ways in which they behave. However, we also recognise that exploring the nature and importance of emotions in identity formation is not explicitly outlined in the SIA and this is a potential weakness of this approach when recognising the intersectional nature of science identity formation.

A further way that the social identity approach provides a useful framework is the concept of interaction, which develops and galvanises social identities (Haslam, 2017). A gap in the literature identified in this review is the explicit understanding of the role of interaction in shaping the extent to which individuals feel part of group membership. For example, Chung-Parsons and Bailey (2019) used the work of Carlone and Johnston (2007) and defined 'science identity' as a combination of performance, competence and recognition, rather than understanding science identity as being achieved through shared group membership. The concept of 'affinity', identified as being present in the literature reviewed, could also be helpfully understood as part of interaction. For example, the affinity observed in the development of science teachers' philosophies in Hsu et al. (2017) could be understood as teachers developing trust in classroom contexts through shared identities as learners. In contrast, a lack of support from preservice teacher mentors, as observed in Ortega et al. (2015), limits the generation of shared identities between student teachers and mentors. Glass (2019) aligned shared group membership with science teacher identity, in contrast to an 
individual's science identity, which Glass (2019) suggested is a personal affinity towards science. As we have argued, science identity entails an affinity with both science and scientists, and therefore group membership is a fundamental part of both science teacher identity and science identity.

Relatedly, Seiler (2011) showed that science identity development for some ethnic minority groups was activated and nurtured through experiences and relationships outside of the classroom and school laboratory because the presentation of science within the school context was at odds with their identity. This is consistent with a wider body of research that explores science identity development in young people, where an individual's perception that science is 'not for people like me' contributes to disengagement and disaffection with science (Dawson, 2014). Similarly, the concept of interaction, where shared social identity is linked to developing a sense of efficacy, agency and power, could be a very helpful way of understanding how affinity develops and how it might be promoted as part of teacher education and professional development programmes. As Richardson (2019) suggested, affinity can be developed through both face-to-face and online media, which could provide a vital opportunity for teachers who may be isolated subject specialists within schools (due to teacher shortages or geography) to develop shared identities that enhance their agency and effectiveness. Identity development in preservice teachers has been a specific focus of researchers (e.g. Chung-Bailey \& Parsons, 2019; Hong et al., 2017; Hsu et al., 2017; Ortega et al., 2015) and these studies recognised the frequently emotionally demanding and time and labour intensive nature of teacher training and accreditation programmes. Using the concepts of identification and interaction, the SIA suggests how individuals may in some circumstances move (back) towards different group memberships as a source of positive social identity. For example, a trainee teacher who is changing their career may, during periods of stress and tension, move their shared identity back to their former profession and, during periods when their self-efficacy as a teacher is high, move their shared identity towards teaching. Having explored how the SIA might support a better understanding of middle and/or high school science teacher identity, we now consider future directions for research that more broadly considers the SIA in the context of school (science) teacher identity.

\section{Future directions for research that considers school (science) teacher identity and the Social Identity Approach}


At the outset of this discussion of future research directions, we contend that although the literature we have considered in this review is focused on middle and/or high school science teachers, there are broad findings which have relevance to teachers of different subjects. As we have argued in this review, the ways in which teachers identify with different groups and the ways in which they interact with those groups shape teacher identity development. Groups can provide communities of practice and supportive spaces for identity development in both online activities such as blogging (e.g. Hanuscin et al., 2014) and in informal science learning spaces including museums (e.g. Adams \& Gupta, 2017). Based upon our review, we recommend that teacher education/training and (continuing) professional development programmes explicitly utilise the framework of the SIA so that teachers not only have a better understanding of how identities are shaped and formed, but are equipped with the relevant knowledge and strategies to respond through the inevitable periods of challenge that they will likely face during the first few years of their teaching career. For example, guidance for teachers frequently underlines the importance of a work-life balance that includes time for teachers' participation in non-work activities that take place outside of school, e.g. team sports or singing in a choir (Education Support Partnership, 2018). Whilst these are of themselves good things to encourage teachers (and indeed the wider population) to do, by explaining the importance of such activities for the maintenance of group membership of multiple different groups, that serve different identity needs, teachers may be more able to see these types of activities as important in maintaining a positive and strong teacher identity. Building on the work of Hanuscin et al. (2014) and Luehmann (2008), future directions for research that explores the role of groups in teacher identity development could extend our understanding of the ways in which online activities (e.g. blogging), networks and social media platforms (e.g. Twitter) create group membership between those who are physically separate by developing online proximity through these virtual platforms. This research theme could also enable comparisons between identities developed online and offline, allowing researchers to consider the ways in which these different sources of identities may function when enacted in the classroom. In this way, and across the other examples previously described, the concept of identification and the role of group membership not only illuminates our considerations of identity development but may also provide additional perspectives and approaches to enhance teachers' professional identity.

Our review has also highlighted the ways in which middle and/or high school science teacher identity is shaped and influenced by the norms (e.g. Kitonga, 2011), values (e.g. 
Rivera Maulucci \& Fann, 2016) and practices (e.g. Allaire, 2013) that are associated with different social identities. By discussing teacher identity through the SIA, both preservice and qualified teachers will be better placed to consider the ways in which their beliefs and values inform their group membership and that of others. This could be a particularly useful strategy for teachers with emerging and more vulnerable professional identities, notably when they experience conflict, tension and challenge either in their preservice placements or in the first years of their careers. Rather than deciding that they are not the teaching 'kind of person', they may thus be helped to conclude that their current context does not suit their developing teacher identity, so that changing schools is more appropriate than leaving the profession altogether. Future research could consider further how the core concept of identification might practically inform understandings of teacher recruitment and retention. For example, the SIA may help researchers understand the role of group membership in shaping the decisions of teachers who choose to leave their schools, or the profession in general, and consider the ways in which increased or enhanced collegiality within their departments and/or schools may be achieved through promoting shared professional identities and how this might be implemented across different settings.

We also argue, based upon our review, that understanding identify formation as a process of interaction, which is a corporate experience rather than a solo enterprise, where shared identity shapes individual sense of self, is a key contribution to better understanding ways to support teacher agency in identity development. Research that draws out the school as a field for identity development (Melville et al., 2007) highlights how important group dynamics are for understanding processes that contribute to identity formation within a department or a school. At a larger scale, research that explores alternative training programmes that are focused on developing socially just teachers (e.g. Marco-Bujosa et al., 2019; Rivera Maulucci, 2013), as well as research that considers the role of cultural context on teacher identity development (Kitonga, 2011; Seiler, 2011), demonstrates the structural and system-related processes that promote or impair positive professional identities. However, this understanding of the role of large-scale processes and structures is yet to inform approaches to teacher continuing professional development. Drawing on both the SIA and our review, we suggest that when an individual teacher identifies that they lack support or control it is crucial to look beyond the needs and perceived deficiencies of that one teacher and consider the broader social context in which they are embedded (Haslam et al., 2018). Using this as a framework for evaluating teacher effectiveness would mean understanding 
this in the context of a department and a school where, rather than ranking the performance of individual teachers, evaluations of teacher performance are considered within the context of the support, control and trust that their context provides. This is a rather different approach to teacher evaluations and performance reviews than that which is found in education systems in the UK and the USA, and it is these countries which contributed much of the literature to this review.

Lastly, we suggest that the concepts of interaction and influence may also provide useful insights into the ways in which teachers' identities are formed and re-formed through their professional relationships with those who mentor and lead them. Our review considered literature that explored identity development in science teachers who were active in research (e.g. Rushton \& Reiss, 2019) as well as those who developed professional dialogue through both online and offline communities (e.g. Bryce et al., 2016) Here, science teachers' identities were shaped through collaboration that developed professional 'alliances' that had aspects similar to that of mentoring relationships. For example, a crucial professional relationship in the life of preservice teacher is that which they share with the teacher who mentors them during their classroom-based practicum. Future research could consider the extent to which reframing the mentor and mentee relationship from that of teacher/student or expert/apprentice to one which seeks to develop a shared interest in 'us' could contribute to more positive and effective mentoring relationships.

In highlighting these areas for future research, we recognise the pressures that teacher education programmes face in terms of delivering courses that strike a balance between pedagogical instruction, subject knowledge enhancement and classroom-based practice and the limited time that teachers have to engage with professional development programmes. And yet, we, along with researchers included in this review (e.g. Grier \& Johnson, 2009; Molander \& Hamza, 2018; Snyder et al., 2013), recognise the critical role that teacher education and development programmes have in providing all teachers with the opportunity to explore and develop their professional identity. With that in mind, we suggest that the SIA could be incorporated into the current content of these programmes, for example through existing sessions that consider teacher well-being and workload, rather than being a further item to add to already busy programmes. To date, this application of the SIA to teacher professional identity is a theoretical proposition; future empirical research in this area will further our understanding of the specific ways in which identity-focused professional development could benefit from the SIA, as well as explore the limitations of this approach, 
in particular the affordances or otherwise of this when considering the identities of teachers working with different age groups (e.g. elementary) and subjects (e.g. music, art, modern foreign languages). Although we do not propose the SIA approach as a universal and/or necessarily superior way to explore teacher identity formation and development, we argue that further theoretical understanding and empirical validation of the role of group processes in education could make an important contribution to identity-focused education research.

\section{Conclusion}

In this review, we have explored to what extent and how the SIA provides a useful lens for understanding research on teacher identity development from the field of education over the last two decades, specifically focused on middle and/or high school science teachers. In doing so, we have considered the ways in which research identified in our systematic review can be situated, or not, within the lens of the SIA. This has included exploring the ways in which teacher identity research contests, supports or extends the five concepts of identification, ideation, interaction, influence and ideology identified by Haslam (2017) that are at the core of understanding the SIA in relation to education. Whilst this use of the SIA as a lens in education is in its infancy, and requires greater theoretical and empirical research, we argue that the SIA draws to the fore the importance of social context and group membership as a fundamental part of a science teacher's identity formation. Until now, the importance of social connectedness and integration has been underestimated in the formation of a teacher's identity and as such the omission of the role of groups has limited the ways in which teachers might sustain positive, purposeful and robust professional identities. Furthermore, we argue that through the five concepts of identification, ideation, interaction, influence and ideology, the SIA enables a greater understanding of how different groups form and why individuals do and do not established certain shared identities.

Our purpose in writing a review at this time was to consider research in the area of science teacher identity which, even in the relatively short time since Avraamidou's (2014a) review, has grown significantly. Through a systematic search of thousands of publications, we identified and synthesised insights from 79 research publications, including 55 articles drawn from 27 different journals (Table 2). Forty three of these research contributions have been published since 2014, and we have included both doctoral research dissertations and theoretical articles (Tables 1 and 4). Consistent with Avraamidou (2014a), this review demonstrates the range of theoretical and conceptual frameworks that researchers have used 
to explore science teacher identity development. We argue that there are a significant number of studies that acknowledge the contribution that social and community contexts make to identity; furthermore, we contend that the SIA provides a useful lens through which to draw out understandings around both the importance of groups and self-categorisation in relation to identity formation from a complex and diverse body of literature and how and why these social processes occur. Indeed, the importance of the role that recognition plays in the formation of science identities was highlighted by Avraamidou (2019), and we suggest that the concept of recognition forms part of identification as described by Haslam (2017). Since Avraamidou's (2014a) review in which she identified future research directions, subsequent research has included a number of large-scale and life history studies, whilst other research has furthered our understanding of the role of context in identity development. We have identified areas for future development where the SIA would provide a useful lens, specifically: (1) considering identity development of non-specialist science teachers including both those from elementary and middle and/or high school contexts through the concept of identification; (2) exploring school science teacher identity development in non-western cultural contexts, and where English is not the first language, through the concept of interaction; and (3) teacher identity development within the context of the school subject department through the concept of influence.

Through the lens of the SIA we have highlighted the crucial role that shared identity and group membership play in the identity development of science teachers and we suggest that this argument is relevant to teachers of other disciplines too. Of particular significance are the ways in which the concepts of identification, ideation, interaction, influence and ideology help us better understand how and when group memberships form and how these mechanisms drive teacher professional identity. This brings a new perspective to teacher education and professional development, as features of professional efficacy, including support, trust and control, are understood as products of group dynamics rather than simply as individual features or characteristics. We hope that this review will provide the impetus for further collaborative work between educators, teachers, psychologists, and sociologists so that they consider, through empirical research, the ways in which teacher identity could be developed and understood in terms of group membership. In order to capture a broad perspective of identity development, such research should include large-scale, longitudinal studies as well as detailed narrative case studies, including life history, autobiographical approaches - and greater co-authorship with teachers. This has the potential to ensure that 
teacher professional development generated from such research is relevant to the fullest range of teachers and contexts.

\section{Acknowledgements}

The authors would like to thank the key informants who kindly identified literature for this study, Nazlin Bhimani for her generous assistance in locating some items of literature and the two anonymous reviewers and Associate Editor for their detailed and insightful comments which substantially improved this work.

The authors reported no conflict of interest.

\section{References}

Adams, J. D., \& Gupta, P. (2017). Informal science institutions and learning to teach: An examination of identity, agency, and affordances. Journal of Research in Science Teaching, 54(1), 121-138.

Akerson, V. L., Pongsanon, K., Weiland, I. S., \& Nargund-Joshi, V. (2014). Developing a professional identity as an elementary teacher of nature of science: A self-study of becoming an elementary teacher. International Journal of Science Education, 36(12), 2055-2082.

Akkerman, S. F., \& P. C. Meijer. (2011). A dialogical approach to conceptualizing teacher identity. Teaching and Teacher Education, 27(2), 308-319.

Allaire, F. S. (2013). Navigating rough waters: Hawaiian science teachers discuss identity. Educational Perspectives, 46, 31-39.

Allen, R. \& Sims, S. (2017). Improving Science Teacher Retention: Do National STEM Learning Network professional development courses keep science teachers in the classroom? Wellcome and Education Datalab. Accessed on 1/07/2019. Available at: https://wellcome.ac.uk/sites/default/files/science-teacher-retention.pdf.

Amundsen, C., \& Wilson, M. (2012). Are we asking the right questions? A conceptual review of the educational development literature in higher education. Review of Educational Research, 82(1), 90-126.

Andrews, R. (2005). The place of systematic reviews in education research. British Journal of Educational Studies, 53(4), 399-416.

Antink-Meyer, A., \& Brown, R. A. (2017). Second-career science teachers' classroom conceptions of science and engineering practices examined through the lens of their

Rushton, E. A. C. \& Reiss, M. J. (2020) Middle and high school science teacher identity considered through 61 the lens of the social identity approach: a systematic review of the literature. Studies in Science Education. DOI: $10.1080 / 03057267.2020 .1799621$. 
professional histories. International Journal of Science Education, 39(11), 15111528.

Avraamidou, L. (2014a). Studying science teacher identity: Current insights and future research directions. Studies in Science Education, 50(2), 145-179.

Avraamidou, L. (2014b). Tracing a beginning elementary teacher's development of identity for science teaching. Journal of Teacher Education, 65(3), 223-240.

Avraamidou, L. (2016). Studying science teacher identity. Theoretical, methodological and empirical explorations. Rotterdam: Sense.

Avraamidou, L. (2019). Science identity as a landscape of becoming: rethinking recognition and emotions through an intersectionality lens. Cultural Studies of Science Education, https://doi.org/10.1007/s11422-019-09954-7.

Bang, E. J., \& Luft, J.A. (2016). Practices and emerging identities of beginning science teachers in online and offline communities of practice. In L. Avraamidou (Ed.), Studying science teacher identity: Theoretical, methodological and empirical explorations (pp. 261-294). Rotterdam: Sense.

Beauchamp, C., \& Thomas, L. (2009). Understanding teacher identity: An overview of issues in the literature and implications for teacher education. Cambridge Journal of Education, 39(2), 175-189.

Beijaard, D., Meijer, P. C., \& Verloop, N. (2004) Reconsidering research on teachers' professional identity. Teaching and Teacher Education 20(2), 107-128.

Beijaard, D., Verloop, N., \& Vermunt, J. D. (2000). Teachers' perceptions of professional identity: An exploratory study from a personal knowledge perspective. Teaching and Teacher Education, 16(7), 749-764.

Bennett, J., Dunlop, L., Knox, K. J., Reiss, M. J., \& Torrance-Jenkins, R. (2018). Practical Independent Research Projects in science: A synthesis and evaluation of the evidence of impact on high school students. International Journal of Science Education 40(14), $1755-1773$.

Blackwell, E. L. (2012). Exploring the positional identities of high-school science teachers. (Doctoral dissertation). Available from ProQuest Dissertation Publishing (2012.3516864).

Boucher, K. L., \& Murphy, M. C. (2017). Why so few? The role of social identity and situational cues in understanding the underrepresentation of women in STEM fields. 
In: K. I. Mavor, M. J. Platow, \& B. Bizumic (Eds.), Self and social identity in educational contexts (pp. 93-111). Oxford: Routledge.

Brand, B. R., \& Glasson, G. E. (2004). Crossing cultural borders into science teaching: Early life experiences, racial and ethnic identities, and beliefs about diversity. Journal of Research in Science Teaching, 41(2), 119-141.

Bryce, N., Wilmes, S. E., \& Bellino, M. (2016). Inquiry identity and science teacher professional development. Cultural Studies of Science Education, 11(2), 235-251.

Burke, P. J., \& Stets, J. (2009). Identity theory. Oxford: Oxford University Press.

Chen, J. L., \& Mensah, F. M. (2018). Teaching contexts that influence elementary preservice teachers' teacher and science teacher identity development. Journal of Science Teacher Education, 29(5), 420-439.

Chetcuti, D. (2009). Identifying a gender-inclusive pedagogy from Maltese teachers' personal practical knowledge. International Journal of Science Education, 31(1), 81-99.

Chi, H. J. (2009). Development and examination of a model of science teacher identity (STI). (Doctoral dissertation). Retrieved from http://rave.ohiolink.edu/etdc/view?acc num $=$ osu1259763038.

Childs, A. (2018). Swimming with the shoal. Cultural Studies of Science Education, 13(2), $539-548$.

Christ, O., van Dick, R., Wagner, U., \& Stellmacher, J. (2003). When teachers go the extra mile: Foci of organisational identification as determinants of different forms of organisational citizenship behaviour among schoolteachers. British Journal of Educational Psychology, 73(3), 329-341.

Chung-Parsons, R., \& Bailey, J. M. (2019). The hierarchical (not fluid) nature of preservice secondary science teachers' perceptions of their science teacher identity. Teaching and Teacher Education, 78, 39-48.

Cochran-Smith, M., Shakman, K., Jong, C., Terrell, D. G., Barnatt, J., \& McQuillan, P. (2009). Good and just teaching: The case for social justice in teacher education. American Journal of Education, 115(3), 347-377.

Cruwys, T., Gaffney, A. M., \& Skipper, Y. (2017). Uncertainty in transition: the influence of group cohesion on learning. In: K. I. Mavor, M. J. Platow, \& B. Bizumic (Eds.), Self and social identity in educational contexts (pp. 193-208). Oxford: Routledge. 
Danielowich, R. M. (2012). Looking through different lenses: How preservice science teachers use practice-oriented reflections to negotiate more reform-minded identities. Journal of Science Teacher Education, 23(4), 323-346.

Danielsson, A., \& Warwick, P. (2014a). 'All we did was things like forces and motion ...': Multiple discourses in the development of primary science teachers. International Journal of Science Education, 36(1), 103-128.

Danielsson, A., \& Warwick, P. (2014b). 'You have to give them some science facts': Primary student teachers' early negotiations of teacher identities in the intersections of discourses about science teaching and about primary teaching. Research in Science Education, 44(2), 289-305.

Davies, P., Connolly, M., Nelson, J., Hulme, M., Kirkman, J., \& Greenway, C. (2016). 'Letting the right one in': Provider contexts for recruitment to initial teacher education in the United Kingdom. Teaching and Teacher Education, 60, 291-302.

Dawson, E. (2014). "Not designed for us": How science museums and science centres socially exclude low-income, minority ethnic groups. Science Education, 98(6), 9811008.

Day, C., Kington, A., Stobart, G., \& Sammons, P. (2006). The personal and professional selves of teachers: Stable and unstable identities. British Educational Research Journal, 32(4), 601-616.

Deneroff, V. (2016). Professional development in person: Identity and the construction of teaching within a high school science department. Cultural Studies of Science Education, 11(2), 213-233.

Department for Education. (2019). Teacher recruitment and retention strategy. London: Department for Education. Available from https://www.gov.uk/government/publications/teacher-recruitment-and-retentionstrategy.

Dominguez, C. R. C., Viviani, L. M., Cazetta, V., Guridi, V. M., Faht, E. C., Pioker, F. C., \& Cubero, J. (2015). Professional choices and teacher identities in the Science Teacher Education Program at EACH/USP. Cultural Studies of Science Education, 10(4), 1189-1213.

Dreon, O. (2008). New science teachers' descriptions of inquiry enactment. (Doctoral dissertation). Retrieved from https://www.researchgate.net/profile/Oliver_Dreon/publication/253123692_New_scie 
nce teachers $\% 27$ descriptions_of inquiry enactment/links/571e06bc08aed056fa226

$\underline{1 \mathrm{bc} / \mathrm{New}-s c i e n c e-t e a c h e r s-d e s c r i p t i o n s-o f-i n q u i r y-e n a c t m e n t . p d f . ~}$

Drewes, A. (2018). Personal, professional, political: An exploration of science teacher identity development for teaching climate change. (Doctoral dissertation). Retrieved from

http://udspace.udel.edu/bitstream/handle/19716/23985/Drewes_udel_0060D_13481.p df? sequence $=1 \&$ is Allowed $=\mathrm{y}$.

Edwards, F. C. E., \& Edwards, R. J. (2017). A story of culture and teaching: The complexity of teacher identity formation. The Curriculum Journal, 28(2), 190-211.

Education Support Partnership (2018). Teacher well-being index 2018. Education Support Partnership. Retrieved from https://www.educationsupportpartnership.org.uk/sites/default/files/teacher_wellbeing index_2018.pdf.

Eick, C. J. (2009). Tailoring national standards to early science teacher identities: Building on personal histories to support beginning practice. Journal of Science Teacher Education, 20(2), 135-156.

Eick, C. J., \& Reed, C. J. (2002). What makes an inquiry-oriented science teacher? The influence of learning histories on student teacher role identity and practice. Science Education, 86(3), 401-416.

Ellemers, N., \& Haslam, S. A. (2012). Social identity theory. In: P. Van Lange, A. Kruglanski, \& T. Higgins (Eds.), Handbook of theories of social psychology (pp. 379398). London: Sage.

El Nagdi, M., Leammukda, F., \& Roehrig, G. (2018). Developing identities of STEM teachers at emerging STEM schools. International Journal of STEM Education, 5(36), https://doi.org/10.1186/s40594-018-0136-1.

Enyedy, N., Goldberg, J., \& Welsh, K. M. (2006). Complex dilemmas of identity and practice. Science Education, 90(1), 68-93.

European Commission/EACEA/Eurydice. (2018). Teaching careers in Europe: Access, progression and support. Eurydice Report. Luxembourg: Publications Office of the European Union.

Fitzgerald, S. T. (2018). Eco-identity: Secondary science teachers' experiences that cultivate place-based teaching in a Hawaiian cultural context. (Doctoral dissertation).

Available from ProQuest LLC (ED589078).

Rushton, E. A. C. \& Reiss, M. J. (2020) Middle and high school science teacher identity considered through 65 the lens of the social identity approach: a systematic review of the literature. Studies in Science Education. DOI: $10.1080 / 03057267.2020 .1799621$. 
Forbes, C. T., \& Biggers, M. (2016). Curricular role identity: What kind of teacher will I be? Teachers' curricular role identity for elementary science. In L. Avraamidou (Ed.), Studying science teacher identity: Theoretical, methodological and empirical explorations (pp. 129-152). Rotterdam: Sense.

Forbes, C., \& Davis, E. A. (2008). Development of preservice elementary teachers' curricular identity for science teaching. Science Education, 92(5), 909-940.

Foster, D. (2018). Teacher recruitment and retention in England. (House of Commons Briefing Paper No. 7222). Retrieved from https://researchbriefings.parliament.uk/ResearchBriefing/Summary/CBP-7222.

Friedrichsen, P., Lannin, J., Abell, S., Arbaugh, F., \& Volkmann, M. (2008). Examining incoming identities in an alternative certification program in mathematics and science. Eurasia Journal of Mathematics, Science \& Technology Education, 4(2), 175-188.

García, E. \& Weiss, E. (2019). The teacher shortage is real, large and growing, and worse than we first thought. (Economic Policy Institute Report). Washington, D.C.: Economic Policy Institute. Retrieved from epi.org/163651.

Garner, J. K., Hathcock, S., \& Kaplan, A. (2016). Exploring the impact of teacher professional development on a veteran science teacher's professional identity: A case study. Paper presented at the 2016 annual meeting of the American Educational Research Association, Washington DC.

Garner, J. K., \& Kaplan, A. (2019). A complex dynamic systems perspective on teacher learning and identity formation: an instrumental case. Teachers and Teaching, 25(1), $7-33$.

Gee, J. P. (2000). Identity as an analytic lens for research in education. Review of Research in Education, 25, 99-125.

Glass, R. (2019). Science identities in the making. Cultural Studies in Science Education, 14(1), 69-76.

Gough, D., Oliver, S., \& Thomas, J. (2012). Introducing systematic reviews. London: Sage. Grier, J. M., \& Johnston, C. C. (2009). An inquiry into the development of teacher identities in STEM career changers. Journal of Science Teacher Education, 20(1), 57-75.

Guzey, S. S., \& Ring-Whalen, E. A. (2018). Negotiating science and engineering: An exploratory case study of a reform-minded science teacher. International Journal of Science Education, 40(7), 723-741. 
Hanuscin, D. L., Cheng, Y. W., Rebello, C., Sinha, S., \& Muslu, N. (2014). The affordances of blogging as a practice to support ninth-grade science teachers' identity development as leaders. Journal of Teacher Education, 65(3), 207-222.

Hanuscin, D., Sinha, S., \& Hall, M. (2016). Supporting teachers in (re)constructing identities as leaders: The role of professional development. In L. Avraamidou (Ed.), Studying science teacher identity: Theoretical, methodological and empirical explorations (pp. 197-218). Rotterdam: Sense.

Harrison, C. (2018). Boundary Crossing during Pre-service Teacher Training: empowering or hampering professional growth?. Cultural Studies of Science Education, 13(4), 11291133.

Haslam, S. A. (2017). The social identity approach to education and learning: identification, ideation, interaction, influence and ideology. In: K. I. Mavor, M. J. Platow, \& B. Bizumic (Eds.), Self and social identity in educational contexts (pp. 19-52). Oxford: Routledge.

Haslam, C., Jetten, J., Cruwys, T., Dingle, G., \& Haslam, S. A. (2018). The new psychology of health. Unlocking the social cure. Oxford: Routledge.

Haslam, S. A., Jetten, J., Postmes, T., \& Haslam, C. (2009). Social identity, health and wellbeing: An emerging agenda for applied psychology. Applied Psychology: An International Review, 58(1), 1-23.

Haslam, S. A., Reicher, S. D., \& Platow, M. J. (2011). The new psychology of leadership: Identity, influence and power. New York: Psychology Press.

Healey, M., Flint, A., \& Harrington, K. (2014). Engagement through partnership: Students as partners in learning and teaching in higher education. York: Higher Education Academy. Retrieved from https://www.heacademy.ac.uk/engagement-through partnership-students-partners-learning-and-teaching-higher-education.

Heredia, S. C., \& Yu, J. H. (2017). A matter of choice: Opportunities for informal science institutions to support science teacher induction. Journal of Science Teacher Education, 28(6), 549-565.

Hong, J., Greene, B., \& Lowery, J. (2017). Multiple dimensions of teacher identity development from pre-service to early years of teaching: A longitudinal study. Journal of Education for Teaching, 43(1), 84-98. 
Hsu, P. L., Reis, G., \& Monarrez, A. (2017). Identity discourse in preservice teachers' science learning autobiographies and science teaching philosophies. Canadian Journal of Science, Mathematics and Technology Education, 17(3), 179-198.

Ibourk, A. (2015). A storied-identity analysis approach to teacher candidates learning to teach in an urban setting. (Doctoral dissertation). Available from ProQuest Dissertations and Theses (AAT 3719769).

Irving-Bell, D. M. (2018). The formation of science, technology, engineering and mathematics teacher identities: Pre-service teachers' perceptions. (Doctoral dissertation). Retrieved from https://eprints.lancs.ac.uk/id/eprint/127684/1/2018DawneMarilynIrving_BellPhD.pdf. Izadinia, M. (2013). A review of research on student teachers' professional identity. British Educational Research Journal, 39(4), 694-713.

Jetten, J., Iyer, A., \& Zhang, A. (2017). The educational experience of students from low socio-economic status background. In: K. I. Mavor, M. J. Platow, \& B. Bizumic (Eds.), Self and social identity in educational contexts (pp. 112-125). Oxford: Routledge.

Jones, S. E., Livingstone, A. G., \& Manstead, A. S. R. (2017). Bullying and belonging: Social identity on the playground. In: K. I. Mavor, M. J. Platow, \& B. Bizumic (Eds.), Self and social identity in educational contexts (pp. 70-90). Oxford: Routledge.

Kane, J. M., \& Varelas, M. (2016). Elementary school teachers constructing teacher-ofscience identities: Two communities of practice coming together. In L. Avraamidou (Ed.), Studying science teacher identity: Theoretical, methodological and empirical explorations (pp. 177-196). Rotterdam: Sense.

Kang, H. (2011). Understanding how secondary science teacher candidates learn to teach: Analyzing the role of knowledge, practice, and professional identity. (Doctoral dissertation). Retrieved from https://www.researchgate.net/publication/258542501_Understanding how secondary science teacher candidates learn to teach Analyzing the role of knowledge pra ctice and professional identity.

Katz, P., McGinnis, R. I., Hestness, E., Riedinger, K., Marbach-Ad, G., Dai, A., \& Pease, R. (2011). Professional identity development of teacher candidates participating in an informal science education internship: A focus on drawings as evidence. International Journal of Science Education, 33(9), 1169-1197. 
Kitonga, N. (2011). Postcolonial construction of self: Two immigrant secondary science teachers from Nigeria and Kenya explore the role of cultural and indigenous beliefs in their teaching. (Doctoral dissertation). Available from ProQuest Dissertations Publishing (2010. 3440233).

Lave, J. (1996). Teaching, as learning, in practice. Mind, Culture and Activity, 3(3), 149-164.

Lew, S. (2016). Science teachers' ESOL professional learning and new hybrid identity development. Electronic Journal of Science Education, 20(3), 32-58.

Luehmann, A. L. (2007). Identity development as a lens to science teacher preparation. Science Education, 91(5), 822-839.

Luehmann, A. L. (2008). Using blogging in support of teacher professional identity development: A case study. The Journal of the Learning Sciences, 17(3), 287-337.

Luehmann, A. (2016). Practice-linked identity development in science teacher education: GET REAL! Science as a figured world. In L. Avraamidou (Ed.), Studying science teacher identity: Theoretical, methodological and empirical explorations (pp. 15-48). Rotterdam: Sense.

Luehmann, A. L., \& Markowitz, D. (2007). Science teachers' perceived benefits of an outofschool enrichment programme: Identity needs and university affordances. International Journal of Science Education, 29(9), 1133-1161.

Luft, J. A. (2009). Beginning secondary science teachers in different induction programmes: The first year of teaching. International Journal of Science Education, 31(17), 23552384.

Luft, J. A., Firestone, J. B., Wong, S. S., Ortega, I., Adams, K., \& Bang, E. (2011). Beginning secondary science teacher induction: A two-year mixed methods study. Journal of Research in Science Teaching, 48(10), 1199-1224.

Luft, J. A., \& Zhang, C. (2014). The pedagogical content knowledge and beliefs of newly hired secondary science teachers: The first three years. Educación Química, 25(3), $325-331$.

Manning, A. (2017). Urban science teachers exploring how their views and experiences can influence decisions to remain in post or not. (Doctoral dissertation). Retrieved from https://core.ac.uk/download/pdf/141244962.pdf.

Marco-Bujosa, L. M., McNeill, K. L., \& Friedman, A. A. (2019) Becoming an urban science teacher: How beginning teachers negotiate contradictory school contexts. Journal of Research in Science Teaching, https://doi.org/10.1002/tea.21583. 
Mavor, K. I., Platow, M. J., \& Bizumic, B. (Eds.) (2017). Self and social identity in educational contexts. Oxford: Routledge.

Mayo, J. S. (2016). From classroom teacher to district-based content specialist: Exploring organizational and individual teacher identity in science teacher leaders. (Doctoral dissertation). Retrieved from https://pdfs.semanticscholar.org/39b0/0822274662cf7aefa70d35252a95b883fa2a.pdf.

McIntyre, J., \& Hobson, A. J. (2016). Supporting beginner teacher identity development: external mentors and the third space. Research Papers in Education, 31(2), 133-158.

Mehli, H., \& Bungum, B. (2013). A space for learning: How teachers benefit from participating in a professional community of space technology. Research in Science \& Technological Education, 31(1), 31-48.

Melville, W., Wallace, J., \& Bartley, A. (2007). Individuals and leadership in an Australian secondary science department: A qualitative study. Journal of Science Education and Technology, 16(6), 463-472.

Melville, W., Bartley, A., \& Fazio, X. (2013). Scaffolding the inquiry continuum and the constitution of identity. International Journal of Science and Mathematics Education, 11(5), 1255-1273.

Mercer-Mapstone, L., Dvorakova, S. L., Matthews, K. E., Abbot, S., Cheng, B. Felten, P., Knorr, K., Marquis, E., Shammas, R., \& Swaim, K. (2017). A systematic literature review of students as partners in higher education. International Journal for Students as Partners 1(1), 1-23.

Molander, B. O., \& Hamza, K. (2018). Transformation of professional identities from scientist to teacher in a short-track science teacher education program. Journal of Science Teacher Education, 29(6), 504-526.

Moons, K. G. M., Hooft, L., Williams, K., Hayden, J. A., Damen, J. A. A. G., \& Riley, R. D. (2018). Implementing systematic reviews of prognosis studies in Cochrane. Cochrane Database of Systematic Reviews (Issue 10. Article No. ED000129). DOI: 10.1002/14651858.ED000129.

Moore, F. M. (2008). Positional identity and science teacher professional development. Journal of Research in Science Teaching, 45(6), 684-710.

Mujtaba, T., \& Reiss, M.J. (2013). Inequality in experiences of physics education: Secondary school girls' and boys' perceptions of their physics education and intentions to 
continue with physics after the age of 16. International Journal of Science Education, 35(11), 1824-1845.

Naidoo, K. (2017). Capturing the transformation and dynamic nature of an elementary teacher candidate's identity development as a teacher of science. Research in Science Education, 47(6), 1331-1355.

Nichols, S. L., Schutz, P. A., Rodgers, K., \& Bilica, K. (2017). Early career teachers' emotion and emerging teacher identities. Teachers and Teaching, 23(4), 406-421.

Nieswandt, M., Barrett, S. E., \& McEneaney, E. H. (2013). Predictors of science subject discipline identities: A statistical analysis. Canadian Journal of Science, Mathematics and Technology Education, 13(1), 90-110.

Oakes, P. J., Haslam, S. A., \& Turner, J. C. (1994). Stereotyping and social reality. Oxford: Blackwell.

O'Doherty, T. \& Hartford, J. (2018). Teacher recruitment: reflections from Ireland on the current crisis in teacher supply. European Journal of Teacher Education, 41(5) 654669.

Ortega, C. M. V., Correa Molina, E., \& Fuentealba Jara, A. R. (2014). La práctica del profesor de Ciencias: Significados personales y experiencias de profesores en formación. Perspectiva Educacional, 54(1), 17-34.

Pedretti, E. G., Bencze, L., Hewitt, J., Romkey, L., \& Jivraj, A. (2008). Promoting issuesbased STSE perspectives in science teacher education: Problems of identity and ideology. Science \& Education, 17(8-9), 941-960.

Proweller, A., \& Mitchener, C. P. (2004). Building teacher identity with urban youth: Voices of beginning middle school science teachers in an alternative certification program. Journal of Research in Science Teaching, 41(10), 1044-1062.

Reynolds, K. J., Subasic, E., Bromhead, D., \& Lee, E. (2017). The school as a group system: School climate, school identity and school outcomes. In: K. I. Mavor, M. J. Platow, \& B. Bizumic (Eds.), Self and social identity in educational contexts (pp. 55-69). Oxford: Routledge.

Richardson, W.D. (2019). Who will stay? How teacher professional identity influences teacher retention decisions in North Carolina secondary science teachers. (Doctoral dissertation). Retrieved from http://www.lib.ncsu.edu/resolver/1840.20/36379.

Richmond, G. (2016). Making sense of the interplay between identity, agency and context in the development of beginning science teachers in high-poverty schools. In L. 
Avraamidou (Ed.), Studying science teacher identity: Theoretical, methodological and empirical explorations (pp. 219-238). Rotterdam: Sense.

Ritchie, S. M. (2009). Looking for Daisy: Constructing teacher identities. Cultural Studies of Science Education, 4(3), 595-599.

Rivera Maulucci, M. S. (2008). Intersections between immigration, language, identity, and emotions: A science teacher candidate's journey. Cultural Studies of Science Education, 3(1), 17-42.

Rivera Maulucci, M. S. (2013). Emotions and positional identity in becoming a social justice science teacher: Nicole's story. Journal of Research in Science Teaching, 50(4), 453478.

Rivera Maulucci, M. S., \& Fann, K.T. (2016). Teaching for social justice in science education: Helping a new teacher develop a social justice identity. In L. Avraamidou (Ed.), Studying science teacher identity: Theoretical, methodological and empirical explorations (pp. 111-128). Rotterdam: Sense.

Rostock, R. (2014). Developing a workable teacher identity: Building and negotiating identity within a professional network. (Doctoral dissertation). Available from ProQuest Dissertations Publishing (2014. 3622668).

Roth, W-M. (2016). Becoming and belonging: From identity to experience as developmental category in science teaching and teacher education. In L. Avraamidou (Ed.), Studying science teacher identity: Theoretical, methodological and empirical explorations (pp. 295-320). Rotterdam: Sense.

Rushton, E. A. C., \& Reiss, M. J. (2019). From science teacher to 'teacher scientist': Exploring the experiences of research-active science teachers in the UK. International Journal of Science Education, 41(11), 1541-1561.

Saka, Y., Southerland, S. A., Kittleson, J., \& Hutner, T. (2013). Understanding the induction of a science teacher: The interaction of identity and context. Research in Science Education, 43(3), 1221-1244.

Schachter, E. P., \& Rich, Y. (2011). Identity education: A conceptual framework for educational researchers and practitioners. Educational Psychologist, 46(4), 222-238.

Scottish Parliament (September, 2017). Teacher workforce planning for Scotland's schools. (SP Paper No.186). Edinburgh: Education and Skills Committee. Retrieved from https://digitalpublications.parliament.scot/Committees/Report/ES/2017/9/1/Teacher- 


\section{Workforce-Planning-for-Scotland-s-Schools\#Summary-of-Conclusions-and-}

\section{Recommendations.}

Seiler, G. (2011). Becoming a science teacher: Moving toward creolized science and an ethic of cosmopolitanism. Cultural Studies of Science Education, 6(1), 13-32.

Settlage, J., Southerland, S. A., Smith, L. K., \& Ceglie, R. (2009). Constructing a doubt-free teaching self: Self-efficacy, teacher identity and science instruction within diverse settings. Journal of Research in Science Teaching, 46(1), 102-125.

Siddaway, A. P., Wood, A. M., \& Hedges, L. V. (2019). How to do a systematic review: A best practice guide for conducting and reporting narrative reviews, meta-analyses, and meta-syntheses. Annual Review of Psychology, 70, 747-770.

Sinha, S., \& Hanuscin, D. L. (2017). Development of teacher leadership identity: A multiple case study. Teaching and Teacher Education, 63, 356-371.

Skolverket. (2017). Pedagogic staff in school and adult education in the school year 2016/17. Stockholm: The Swedish National Agency for Education. Available from https://www.skolverket.se/andra-sprak-other-languages/english-engelska.

Snyder, C., Oliveira, A. W., \& Paska, L. M. (2013). STEM career changers' transformation into science teachers. Journal of Science Teacher Education, 24(4), 617-644.

Subryan, S. (2016). Exploring secondary school science teacher professional identity: Can it be influenced and reshaped by experiences of professional development programmes? (Doctoral dissertation). Retrieved from https://derby.openrepository.com/handle/10545/621337.

Sutcher, L., Darling-Hammond, L., \& Carver-Thomas, D. (2016). A coming crisis in teaching? Teacher supply, demand and shortages in the U.S. Washington, DC: Learning Policy Institute Report. Retrieved from: https://learningpolicyinstitute.org/sites/default/files/productfiles/A Coming_Crisis in Teaching_REPORT.pdf.

Tajfel, H., \& Turner, J. C. (1979). An integrative theory of inter-group conflict. In W. G. Austin \& S. Worchel (Eds.), The social psychology of intergroup relations (pp. 3347). Monterey, CA: Brooks-Cole.

Turner, J. C. (1982). Towards a cognitive redefinition of the social group. In: H. Tajfel (Ed.), Social identity and intergroup relations (pp. 15-40). Paris: Editions de la Maison des Sciences de l'Homme. 
Turner, J. C., Hogg, M. A., Oakes, P. J., Reicher, S. D., \& Wetherell, M. S. (1987). Rediscovering the social group: A self-categorization theory. Cambridge, MA: Blackwell.

Ufnar, J. A., \& Shepherd, V. L. (2019). The Scientist in the Classroom Partnership program: An innovative teacher professional development model. Professional Development in Education, 45(4), 642-658.

Upadhyay, B. (2009). Negotiating identity and science teaching in a high-stakes testing environment: An elementary teacher's perceptions. Cultural Studies of Science Education, 4(3), 569-586.

van Dick, R., \& Wagner, U. (2001). Stress and strain in teaching: A structural equation approach. British Journal of Educational Psychology, 71(2), 243-259.

van Dick, R., \& Wagner, U. (2002). Social identification among school teachers: Dimensions, foci, and correlates. European Journal of Work and Organizational Psychology, 11(2), 129-149.

Varelas, M., House, R., \& Wenzel, S. (2005). Beginning teachers immersed into science: Scientist and science teacher identities. Science Education, 89(3), 492-516.

Volkmann, M., \& Anderson, M. (1998). Creating professional identity: Dilemmas and metaphors of a first-year chemistry teacher. Science Education, 82, 293-310.

Vygotsky, L. S. (2005). Psychology of human development. Moscow: Eksmo.

Watters, J. J., \& Diezmann, C. M. (2015). Challenges confronting career-changing beginning teachers: A qualitative study of professional scientists becoming science teachers. Journal of Science Teacher Education, 26(2), 163-192.

Webb, A.W. (2012). “Supporting” beginning secondary science teachers through induction: A multi-case study of their meaning making and identities. (Doctoral dissertation). Available from ProQuest Dissertations (2012. 3525801).

Wenger, E. (1998). Communities of practice: Learning, meaning, and identity. Cambridge, UK: Cambridge University Press.

Weldon, P. (2018). Early career teacher attrition in Australia: Evidence, definition, classification and measurement. Australian Journal of Education, 6(1), 61-78.

West, R. J. (2015). Teacher identity and self-efficacy development in an alternative licensure program for middle and high school math and science teachers. (Doctoral dissertation). Retrieved from http://rave.ohiolink.edu/etdc/view?acc num=ohiou1427381851.

Rushton, E. A. C. \& Reiss, M. J. (2020) Middle and high school science teacher identity considered through 74 the lens of the social identity approach: a systematic review of the literature. Studies in Science Education. DOI: 10.1080/03057267.2020.1799621. 
Whitacre, M. P. (2015). Teacher transformation: An exploration of science teachers' changing professional identities, knowledge, and classroom practices. (Doctoral dissertation). Available from ProQuest Dissertations (2015.3705202).

Wilson, E., \& Deaney, R. (2010). Changing career and changing identity: How do teacher career changers exercise agency in identity construction?. Social Psychology of Education, 13(2), 169-183.

Woolhouse, C., \& Cochrane, M. (2015). Educational policy or practice? Traversing the conceptual divide between subject knowledge, pedagogy and teacher identity in England. European Journal of Teacher Education, 38(1), 87-101. 
Table 1: Publications reviewed: purpose and methods used ${ }^{1}$

\begin{tabular}{|c|c|c|}
\hline Author(s)/Publication & Purpose & Methods \\
\hline $\begin{array}{l}\text { Adams and Gupta } \\
\text { (2017) JRST }\end{array}$ & $\begin{array}{l}\text { To explore the role of informal science } \\
\text { institutions as a space for trainee high } \\
\text { school science teacher education using } \\
\text { the framework of identity in relation to } \\
\text { agency as experienced by } 36 \\
\text { preservice teachers during a Master of } \\
\text { Arts in Teaching program based in a } \\
\text { museum. }\end{array}$ & $\begin{array}{l}\text { Qualitative methods. } \\
\text { Data sources: semi-structured conversations } \\
\text { with preservice teachers after a session } \\
\text { working with the museum public, } \\
\text { preservice teachers' responses to surveys, } \\
\text { online forum posts and authors' field notes. }\end{array}$ \\
\hline $\begin{array}{l}\text { Allaire (2013) } \\
\text { EP }\end{array}$ & $\begin{array}{l}\text { To explore the relationship between } \\
\text { identities as science educators and as a } \\
\text { Native Hawaiians through the life } \\
\text { histories of two Native Hawaiian high } \\
\text { school science teachers and one } \\
\text { informal science educator. }\end{array}$ & $\begin{array}{l}\text { Qualitative methods - life histories and } \\
\text { personal narratives. } \\
\text { Data sources: in person semi-structured } \\
\text { interviews and follow-up phone calls and } \\
\text { emails. }\end{array}$ \\
\hline $\begin{array}{l}\text { Antink-Meyer and } \\
\text { Brown (2017) IJSE }\end{array}$ & $\begin{array}{l}\text { To explore the relationship between } \\
\text { STEM practices in the workplace and } \\
\text { the classroom through the perspectives } \\
\text { of four second-career high school } \\
\text { science teachers, and to understand } \\
\text { their perceptions of best practice in } \\
\text { STEM teaching. }\end{array}$ & $\begin{array}{l}\text { Qualitative methods - descriptive case } \\
\text { study. } \\
\text { Data sources: semi-structured interviews, } \\
\text { classroom observations. }\end{array}$ \\
\hline $\begin{array}{l}\text { Avraamidou (2014) } \\
\text { SSE }\end{array}$ & $\begin{array}{l}\text { A review and synthesis of } 29 \text { peer- } \\
\text { reviewed articles to better understand } \\
\text { the ways in which identity has been } \\
\text { used as a lens to examine K-12 science } \\
\text { teacher learning and development. }\end{array}$ & $\begin{array}{l}\text { Review of } 11 \text { journals over a 12-year } \\
\text { period (2001-2013) that identified } 29 \\
\text { empirical studies whose findings were } \\
\text { synthesised in the review. }\end{array}$ \\
\hline $\begin{array}{l}\text { Bang and Luft (2016) } \\
\text { in Avraamidou (2016) }\end{array}$ & $\begin{array}{l}\text { To explore changes in identity of } \\
\text { beginning high school science teachers } \\
\text { who participated in an online, science- } \\
\text { specific mentoring program over a } \\
\text { two-year period. }\end{array}$ & $\begin{array}{l}\text { Mixed method study which included focal } \\
\text { case studies with three high school science } \\
\text { teachers and qualitative and quantitative } \\
\text { data from a large group of } 14 \text { high school } \\
\text { science teachers. } \\
\text { Data sources: demographic survey, mentor } \\
\text { applications, semi-structured monthly and } \\
\text { yearly interviews, classroom observations, } \\
\text { written synchronous threaded online posts }\end{array}$ \\
\hline $\begin{array}{l}\text { Beijaard et al. (2000) } \\
\text { TTE }\end{array}$ & $\begin{array}{l}\text { To investigate } 80 \text { experienced high } \\
\text { school teachers' perceptions of their } \\
\text { professional identity, including } 27 \\
\text { science and mathematics teachers. }\end{array}$ & $\begin{array}{l}\text { Quantitative and qualitative methods. } \\
\text { Data sources: survey responses. }\end{array}$ \\
\hline $\begin{array}{l}\text { Blackwell (2012) } \\
\text { Dissertation }\end{array}$ & $\begin{array}{l}\text { To investigate the positional identity of } \\
\text { five high school science teachers of } \\
\text { different ethnicities and see how their } \\
\text { positional identities influence their } \\
\text { classroom practices. }\end{array}$ & $\begin{array}{l}\text { Qualitative approaches. } \\
\text { Data sources: classroom observations, } \\
\text { structured, and semi-structured interviews, } \\
\text { book club meetings, teacher journals, } \\
\text { researcher journals, and demographic and } \\
\text { online questionnaires. }\end{array}$ \\
\hline
\end{tabular}

\footnotetext{
${ }^{1}$ Throughout Table 1, the spelling of the term program / programme is kept consistent with the spelling in the original publication.

Rushton, E. A. C. \& Reiss, M. J. (2020) Middle and high school science teacher identity considered through 76 the lens of the social identity approach: a systematic review of the literature. Studies in Science Education.

DOI: $10.1080 / 03057267.2020 .1799621$.
} 


\begin{tabular}{|c|c|c|}
\hline $\begin{array}{l}\text { Brand and Glasson } \\
\text { (2004) JRST }\end{array}$ & $\begin{array}{l}\text { To explore the development of belief } \\
\text { systems as related to racial and ethnic } \\
\text { identities of preservice high school } \\
\text { science teachers as they crossed } \\
\text { cultural borders into science teaching. }\end{array}$ & $\begin{array}{l}\text { Qualitative ethnographic study of three } \\
\text { preservice teachers during their student } \\
\text { teacher training year. } \\
\text { Data sources: open-ended interviews, } \\
\text { participant reflections, weekly activity logs, } \\
\text { field notes from observations of } \\
\text { participants. }\end{array}$ \\
\hline $\begin{array}{l}\text { Bryce et al. (2016) } \\
\text { CSSE }\end{array}$ & $\begin{array}{l}\text { Theoretical article that considers ways } \\
\text { in which to promote inquiry identity } \\
\text { formation and collaboration to improve } \\
\text { professional efficacy in science } \\
\text { teaching and learning. }\end{array}$ & $\begin{array}{l}\text { Discursive, theoretical paper explicitly } \\
\text { voiced by the three authors. }\end{array}$ \\
\hline $\begin{array}{l}\text { Chi (2009) } \\
\text { Dissertation }\end{array}$ & $\begin{array}{l}\text { Introduces the conceptual model of } \\
\text { Science Teacher Identity (STI)) and } \\
\text { the development of a new survey } \\
\text { instrument to measure STI. }\end{array}$ & $\begin{array}{l}\text { Quantitative and qualitative methods. } \\
\text { Data sources: case studies, including } \\
\text { interviews and document analysis of } 17 \\
\text { preservice high school science teachers, } \\
\text { survey data from } 414 \text { preservice elementary } \\
\text { and high school science teachers. }\end{array}$ \\
\hline $\begin{array}{l}\text { Childs (2018) } \\
\text { CSSE }\end{array}$ & $\begin{array}{l}\text { To explore the development of science } \\
\text { teacher identity in a culture that is } \\
\text { unfamiliar to the teacher from the } \\
\text { experiences of an individual high } \\
\text { school science teacher from the UK } \\
\text { who taught in Sierra Leone and } \\
\text { worked as a teacher educator in } \\
\text { Bhutan. }\end{array}$ & $\begin{array}{l}\text { Qualitative self-study } \\
\text { Data sources: an individual's personal } \\
\text { reflections drawn from two case studies. }\end{array}$ \\
\hline $\begin{array}{l}\text { Chung-Parsons and } \\
\text { Bailey (2019) } \\
\text { TTE }\end{array}$ & $\begin{array}{l}\text { To explore three preservice US high } \\
\text { school science teachers' conceptions of } \\
\text { their professional teacher identity and } \\
\text { their subject matter identity, and the } \\
\text { contexts within which they draw upon } \\
\text { those science teacher identities for } \\
\text { teaching. }\end{array}$ & $\begin{array}{l}\text { Qualitative methods, case study and cross- } \\
\text { case study approach, grounded in a figured } \\
\text { worlds approach. } \\
\text { Data sources: semi-structured individual } \\
\text { and focus group interviews, observations of } \\
\text { seminars and in classrooms and documents } \\
\text { including lesson plans, unit plan, weekly } \\
\text { journal reflections, teaching philosophy } \\
\text { statement, reflective essay. }\end{array}$ \\
\hline $\begin{array}{l}\text { Danielowich (2012) } \\
\text { JSTE }\end{array}$ & $\begin{array}{l}\text { To explore the development of reform- } \\
\text { minded ideas in six preservice high } \\
\text { school science teachers through field } \\
\text { lessons taught during a methods course } \\
\text { and student-teaching. }\end{array}$ & $\begin{array}{l}\text { Qualitative methods. } \\
\text { Data sources: written reflections. }\end{array}$ \\
\hline $\begin{array}{l}\text { Deneroff (2016) } \\
\text { CSSE }\end{array}$ & $\begin{array}{l}\text { To explore the role of professional } \\
\text { development on the identity } \\
\text { construction and teaching practices of } \\
\text { an exemplary urban high school } \\
\text { science teacher. }\end{array}$ & $\begin{array}{l}\text { Qualitative methods, an ethnographic study } \\
\text { over three years. } \\
\text { Data sources: multiple interviews and } \\
\text { classroom observations. }\end{array}$ \\
\hline $\begin{array}{l}\text { Dominguez et al. } \\
\text { (2015) } \\
\text { CSSE }\end{array}$ & $\begin{array}{l}\text { To understand the decision-making } \\
\text { processes of } 39 \text { students in choosing to } \\
\text { become a science teacher and to make } \\
\text { sense of the relationships between this } \\
\text { process and the formation of their } \\
\text { identity as a science teacher. }\end{array}$ & $\begin{array}{l}\text { Qualitative methods. } \\
\text { Data sources: written narrative reflections. }\end{array}$ \\
\hline $\begin{array}{l}\text { Dreon }(2008) \\
\text { Dissertation }\end{array}$ & $\begin{array}{l}\text { To examine the experiences of two } \\
\text { early career science teachers (one } \\
\text { teaching in a rural middle school and }\end{array}$ & $\begin{array}{l}\text { Qualitative methods, a phenomenological } \\
\text { study. }\end{array}$ \\
\hline
\end{tabular}

Rushton, E. A. C. \& Reiss, M. J. (2020) Middle and high school science teacher identity considered through 77 the lens of the social identity approach: a systematic review of the literature. Studies in Science Education.

DOI: $10.1080 / 03057267.2020 .1799621$. 


\begin{tabular}{|c|c|c|}
\hline & $\begin{array}{l}\text { the other in an urban high school) who } \\
\text { enact inquiry pedagogy. }\end{array}$ & $\begin{array}{l}\text { Data sources: semi-structured interviews, } \\
\text { online journal postings, classroom } \\
\text { observations. }\end{array}$ \\
\hline $\begin{array}{l}\text { Drewes (2018) } \\
\text { Dissertation }\end{array}$ & $\begin{array}{l}\text { To explore how } 15 \text { middle/high school } \\
\text { (urban, suburban and rural) science } \\
\text { teachers' lived experiences shape their } \\
\text { science teacher identity development } \\
\text { as teachers of climate change. }\end{array}$ & $\begin{array}{l}\text { Qualitative methods, narrative inquiry. } \\
\text { Data sources: semi-structured interviews, } \\
\text { written reflections. }\end{array}$ \\
\hline $\begin{array}{l}\text { Edwards and Edwards } \\
\text { (2017) CJ }\end{array}$ & $\begin{array}{l}\text { To explore the role of culture in the } \\
\text { identity formation of an individual } \\
\text { high school science teacher over the } \\
\text { course of their teacher training and } \\
\text { first year as a teacher. }\end{array}$ & $\begin{array}{l}\text { Qualitative, two-year longitudinal study } \\
\text { focused on an individual. } \\
\text { Data sources: semi-structured interviews. }\end{array}$ \\
\hline $\begin{array}{l}\text { Eick (2009) } \\
\text { JSTE }\end{array}$ & $\begin{array}{l}\text { To examine the place of Individual } \\
\text { Recommendation Plans (IRPs) in the } \\
\text { identity formation of two preservice } \\
\text { high school science teachers. }\end{array}$ & $\begin{array}{l}\text { Qualitative methods, case study of two } \\
\text { individuals over the course of an academic } \\
\text { year. } \\
\text { Resume task, semi-structured interviews, } \\
\text { Index of Learning Styles survey. }\end{array}$ \\
\hline $\begin{array}{l}\text { Eick and Reed (2002) } \\
\text { SCIED }\end{array}$ & $\begin{array}{l}\text { To explore the role of personal } \\
\text { histories in the formation of teachers' } \\
\text { identities as inquiry-oriented high } \\
\text { school science teachers. The study } \\
\text { includes } 12 \text { high school science } \\
\text { teachers during their student teacher } \\
\text { placement. }\end{array}$ & $\begin{array}{l}\text { Qualitative methods. } \\
\text { Data sources: interviews with teachers and } \\
\text { written reflections. }\end{array}$ \\
\hline $\begin{array}{l}\text { El Nagdi et al. (2018) } \\
\text { IJStemE }\end{array}$ & $\begin{array}{l}\text { To explore the context of STEM } \\
\text { schools as places to develop STEM } \\
\text { teacher identities, drawing on the } \\
\text { experiences of eight high school } \\
\text { STEM teachers at two STEM schools } \\
\text { over the course of a year. }\end{array}$ & $\begin{array}{l}\text { Qualitative methods using grounded theory } \\
\text { approach. } \\
\text { Data sources: semi-structured interviews. }\end{array}$ \\
\hline $\begin{array}{l}\text { Enyedy et al. (2005) } \\
\text { SCIED }\end{array}$ & $\begin{array}{l}\text { To examine the ways two experienced } \\
\text { high school science teachers, talk } \\
\text { about their identity and teacher } \\
\text { practices in the context of } \\
\text { implementing a new environmental } \\
\text { science curriculum (GLOBE). }\end{array}$ & $\begin{array}{l}\text { Qualitative methods. } \\
\text { Data sources: three types of interviews } \\
\text { (semi-structured individual and group } \\
\text { interviews, informal interviews) with two } \\
\text { teachers who implemented a specified } \\
\text { curriculum for three months. Self-reports of } \\
\text { practice and recordings of teaching } \\
\text { practices. }\end{array}$ \\
\hline $\begin{array}{l}\text { Fitzgerald (2018) } \\
\text { Dissertation }\end{array}$ & $\begin{array}{l}\text { To explore the multifaceted identities, } \\
\text { including eco-identities, of six high } \\
\text { school science teachers, teaching in the } \\
\text { Hawaiian cultural context over a five- } \\
\text { year period. }\end{array}$ & $\begin{array}{l}\text { Qualitative methods using narrative inquiry } \\
\text { and grounded theory approach. } \\
\text { Data sources: repeated, individual semi- } \\
\text { structured interviews. }\end{array}$ \\
\hline $\begin{array}{l}\text { Friedrichsen et al. } \\
\text { (2008) EJMSTE }\end{array}$ & $\begin{array}{l}\text { To explore the incoming identities of a } \\
\text { cohort of } 19 \text { preservice high school } \\
\text { science and mathematics teachers } \\
\text { participating in a } 15 \text {-month long } \\
\text { alternative certification program } \\
\text { (ACP). }\end{array}$ & $\begin{array}{l}\text { Qualitative methods, case study of a } \\
\text { complete cohort of preservice teachers. } \\
\text { Data sources: semi-structured interviews, } \\
\text { course application materials, course } \\
\text { artefacts (e.g. autobiographies, online } \\
\text { discussions). }\end{array}$ \\
\hline $\begin{array}{l}\text { Garner et al. (2016) } \\
\text { AERA }\end{array}$ & $\begin{array}{l}\text { Case study which draws on the } \\
\text { Dynamic Systems Model of Role } \\
\text { Identity (DSMRI) to explore the }\end{array}$ & $\begin{array}{l}\text { Qualitative methods. } \\
\text { Data sources: semi-structured interviews } \\
\text { with an individual teacher. }\end{array}$ \\
\hline
\end{tabular}

Rushton, E. A. C. \& Reiss, M. J. (2020) Middle and high school science teacher identity considered through 78 the lens of the social identity approach: a systematic review of the literature. Studies in Science Education. DOI: $10.1080 / 03057267.2020 .1799621$. 


\begin{tabular}{|c|c|c|}
\hline & $\begin{array}{l}\text { identity of a single veteran high school } \\
\text { science teacher who participated in a } \\
\text { summer professional development } \\
\text { institute program. }\end{array}$ & \\
\hline $\begin{array}{l}\text { Garner and Kaplan } \\
\text { (2018) TT }\end{array}$ & $\begin{array}{l}\text { To introduce the Dynamic Systems } \\
\text { Model of Role Identity (DSMRI) and } \\
\text { explore its application through an } \\
\text { instrumental case study of a high } \\
\text { school physics teacher (with over } 20 \\
\text { years teaching experience) who } \\
\text { participated in a professional } \\
\text { development programme which } \\
\text { supported inquiry-based classroom } \\
\text { methods. }\end{array}$ & $\begin{array}{l}\text { Qualitative methods. } \\
\text { Data sources: repeated semi-structured } \\
\text { interviews. }\end{array}$ \\
\hline Glass (2019) CSSE & $\begin{array}{l}\text { Responds to Avraamidou's (2014) } \\
\text { article. Glass (2019) suggests it is } \\
\text { important to acknowledge a distinction } \\
\text { between a 'science identity' and a } \\
\text { 'science teacher identity'. }\end{array}$ & $\begin{array}{l}\text { Commentary article that brings new } \\
\text { perspectives in response to Avraamidou } \\
\text { (2014). }\end{array}$ \\
\hline $\begin{array}{l}\text { Grier and Johnston } \\
\text { (2009) JSTE }\end{array}$ & $\begin{array}{l}\text { To explore the development of } \\
\text { teaching identities in six STEM career- } \\
\text { changing preservice high school } \\
\text { STEM teachers during a university- } \\
\text { based teacher credential program. }\end{array}$ & $\begin{array}{l}\text { Qualitative research with a naturalistic } \\
\text { design. } \\
\text { Data sources: interviews, field } \\
\text { observations, analysis of curriculum } \\
\text { products. }\end{array}$ \\
\hline $\begin{array}{l}\text { Guzey and Ring- } \\
\text { Whalen (2018) IJSE }\end{array}$ & $\begin{array}{l}\text { To explore the development of a } \\
\text { middle school science teacher's (mid- } \\
\text { career teacher - eight years teaching } \\
\text { experience) reform-minded identity } \\
\text { over nine months in response to } \\
\text { changes in the science curriculum. }\end{array}$ & $\begin{array}{l}\text { Qualitative research with a case study } \\
\text { design. } \\
\text { Data sources: monthly interviews, video } \\
\text { recordings of classroom lessons, field notes } \\
\text { from classroom observations. }\end{array}$ \\
\hline $\begin{array}{l}\text { Hanuscin et al. (2014) } \\
\text { JTE }\end{array}$ & $\begin{array}{l}\text { To examine the role of blogging as } \\
\text { professional development for high } \\
\text { school science teacher leaders by } \\
\text { exploring the ways in which teacher } \\
\text { bloggers develop identities. }\end{array}$ & $\begin{array}{l}\text { Qualitative methods. } \\
\text { Data sources: } 36 \text { individuals' blogs, with } \\
\text { responses and replies over the course of a } \\
\text { year. }\end{array}$ \\
\hline $\begin{array}{l}\text { Hanuscin et al. (2016) } \\
\text { in Avraamidou (2016) }\end{array}$ & $\begin{array}{l}\text { To explore science teacher identity } \\
\text { through the lens of leadership, drawing } \\
\text { on examples from teacher professional } \\
\text { development programs and vignettes } \\
\text { from a participating high school } \\
\text { science teacher. }\end{array}$ & $\begin{array}{l}\text { Theoretical paper with case study } \\
\text { approaches. } \\
\text { Data sources: vignettes from one high } \\
\text { school science teacher, author's reflections } \\
\text { on teacher professional development } \\
\text { programs. }\end{array}$ \\
\hline Harrison (2018) CCSE & $\begin{array}{l}\text { Considers the place of 'boundary } \\
\text { crossing' (where individuals } \\
\text { experience contrasting socio-cultural } \\
\text { contexts) in the development of pre- } \\
\text { service high school science teachers } \\
\text { and whether this generates or impairs } \\
\text { professional growth. }\end{array}$ & $\begin{array}{l}\text { Theoretical paper in response to Rahmawati } \\
\text { and Taylor (2017). }\end{array}$ \\
\hline $\begin{array}{l}\text { Heredia and } \mathrm{Yu}(2017) \\
\text { JSTE }\end{array}$ & $\begin{array}{l}\text { To explore how a two-year induction } \\
\text { program for high school science } \\
\text { teachers provided by an informal } \\
\text { science institution supported critical } \\
\text { areas of understanding needed by new } \\
\text { science teachers. }\end{array}$ & $\begin{array}{l}\text { Qualitative methods. } \\
\text { Data sources: survey completed by } 143 \\
\text { respondents and individual telephone } \\
\text { interviews with } 13 \text { participants. }\end{array}$ \\
\hline
\end{tabular}

Rushton, E. A. C. \& Reiss, M. J. (2020) Middle and high school science teacher identity considered through 79 the lens of the social identity approach: a systematic review of the literature. Studies in Science Education.

DOI: $10.1080 / 03057267.2020 .1799621$. 


\begin{tabular}{|c|c|c|}
\hline $\begin{array}{l}\text { Hong et al. (2017) } \\
\text { JET }\end{array}$ & $\begin{array}{l}\text { To explore the development of teacher } \\
\text { identity in five high school science } \\
\text { teachers over four years, from their } \\
\text { pre-service year until their third year of } \\
\text { teaching. }\end{array}$ & $\begin{array}{l}\text { Qualitative, longitudinal study over four } \\
\text { years. } \\
\text { Data sources: three phases of interviews } \\
\text { with five pre-service teachers. }\end{array}$ \\
\hline $\begin{array}{l}\text { Hsu et al. (2017) } \\
\text { CJSMTE }\end{array}$ & $\begin{array}{l}\text { To explore how } 38 \text { preservice middle } \\
\text { school science teachers' identities were } \\
\text { manifested in their philosophies of } \\
\text { science learning and teaching. }\end{array}$ & $\begin{array}{l}\text { Qualitative methods. } \\
\text { Data sources: } 76 \text { essays focused on the } \\
\text { participants' teaching philosophies and } \\
\text { learning autobiographies. }\end{array}$ \\
\hline $\begin{array}{l}\text { Ibourk (2015) } \\
\text { Dissertation }\end{array}$ & $\begin{array}{l}\text { To examine the identity development } \\
\text { of three preservice high school science } \\
\text { teachers participating in a scholarship } \\
\text { program which included a nine-month } \\
\text { placement in a high needs school. }\end{array}$ & $\begin{array}{l}\text { Qualitative methods, 'storied identity' } \\
\text { framework and grounded theory approach. } \\
\text { Data sources: participants' reflection } \\
\text { journals, written participation in online } \\
\text { discussion forum, lesson plans and } \\
\text { reflections and semi-structured interviews. }\end{array}$ \\
\hline $\begin{array}{l}\text { Irving-Bell (2018) } \\
\text { Dissertation }\end{array}$ & $\begin{array}{l}\text { To explore the personal teaching } \\
\text { philosophies of those training to be } \\
\text { qualified high school STEM teachers } \\
\text { and consider the ways in which } \\
\text { experience-related beliefs shape their } \\
\text { identities. }\end{array}$ & $\begin{array}{l}\text { Qualitative methods using a constructivist } \\
\text { grounded theory approach. } \\
\text { Data sources: pilot survey, semi-structured } \\
\text { interviews, email correspondence, focus } \\
\text { group interviews. }\end{array}$ \\
\hline $\begin{array}{l}\text { Kang (2011) } \\
\text { Dissertation }\end{array}$ & $\begin{array}{l}\text { To examine how a group of } 14 \\
\text { preservice high school science } \\
\text { teachers, enrolled on the same teacher } \\
\text { instruction program, develop different } \\
\text { kinds of practices of science teaching } \\
\text { and how this relates to their designated } \\
\text { identities. }\end{array}$ & $\begin{array}{l}\text { Qualitative methods. } \\
\text { Data sources: interviews, classroom videos } \\
\text { and teaching mission statements from } 14 \\
\text { trainee teachers, } 14 \text { teacher mentors and } \\
\text { two university course instructors. }\end{array}$ \\
\hline $\begin{array}{l}\text { Kitonga (2011) } \\
\text { Dissertation }\end{array}$ & $\begin{array}{l}\text { To explore how the beliefs and } \\
\text { meaning making and teaching of two } \\
\text { in-service, immigrant high school } \\
\text { science teachers to the USA from } \\
\text { Nigeria and Kenya are shaped by their } \\
\text { cultural contexts. }\end{array}$ & $\begin{array}{l}\text { Qualitative methods, co-participatory life } \\
\text { histories. } \\
\text { Data sources: formal dialogues, researcher } \\
\text { reflective journal, email conversations, } \\
\text { lesson plans, teacher reflections. }\end{array}$ \\
\hline $\begin{array}{l}\text { Lew (2016) } \\
\text { EJSE }\end{array}$ & $\begin{array}{l}\text { To explore the identity development of } \\
\text { four in-service high school science } \\
\text { teachers who completed an } 18 \text { month- } \\
\text { long ESOL (English to Speakers of } \\
\text { Other Languages) professional } \\
\text { development program and the } \\
\text { enactment of this identity in the } \\
\text { science classroom. }\end{array}$ & $\begin{array}{l}\text { Qualitative methods with case study } \\
\text { approach. } \\
\text { Data sources: classroom observations, } \\
\text { interviews, teacher journals and classroom } \\
\text { assignments. }\end{array}$ \\
\hline $\begin{array}{l}\text { Luehmann (2007) } \\
\text { SCIED }\end{array}$ & $\begin{array}{l}\text { Uses identity as a lens to consider the } \\
\text { professional development challenges } \\
\text { encountered by reform-minded middle } \\
\text { and high school science teachers and } \\
\text { how teacher preparation courses may } \\
\text { better prepare early career teachers. }\end{array}$ & Theoretical paper. \\
\hline $\begin{array}{l}\text { Luehmann (2008) } \\
\text { JLS }\end{array}$ & $\begin{array}{l}\text { To explore the ways in which blogging } \\
\text { over the course of an academic year } \\
\text { provided a middle school science } \\
\text { teacher (in an urban setting) with the } \\
\text { opportunity to develop her professional } \\
\text { identity. }\end{array}$ & $\begin{array}{l}\text { Qualitative methods. } \\
\text { Data sources: } 316 \text { blog posts published } \\
\text { during one academic year, interviews, } \\
\text { email communication. }\end{array}$ \\
\hline
\end{tabular}

Rushton, E. A. C. \& Reiss, M. J. (2020) Middle and high school science teacher identity considered through 80 the lens of the social identity approach: a systematic review of the literature. Studies in Science Education.

DOI: $10.1080 / 03057267.2020 .1799621$. 


\begin{tabular}{|c|c|c|}
\hline $\begin{array}{l}\text { Luehmann (2016) in } \\
\text { Avraamidou (2016) }\end{array}$ & $\begin{array}{l}\text { To understand the place of identity in } \\
\text { teacher education in the context of a } \\
15 \text {-month masters teacher education } \\
\text { program focused on reform-minded } \\
\text { teacher training. }\end{array}$ & $\begin{array}{l}\text { Theoretical paper with qualitative data } \\
\text { drawn from a case study. } \\
\text { Data sources: field experiences of one high } \\
\text { school science teacher. }\end{array}$ \\
\hline $\begin{array}{l}\text { Manning (2017) } \\
\text { Dissertation }\end{array}$ & $\begin{array}{l}\text { To explore the experiences of five } \\
\text { science teachers working at the same } \\
\text { high school over a four-year period } \\
\text { and the ways in which their personal, } \\
\text { professional and situated identities } \\
\text { inform their role construction as a } \\
\text { science teacher. }\end{array}$ & $\begin{array}{l}\text { Qualitative methods, life histories } \\
\text { approach. } \\
\text { Data sources: classroom observations and } \\
\text { interviews with five participants. }\end{array}$ \\
\hline $\begin{array}{l}\text { Marco-Bujosa et al. } \\
\text { (2019) } \\
\text { JRST }\end{array}$ & $\begin{array}{l}\text { To explore how four novice science } \\
\text { teachers negotiated and enacted their } \\
\text { political awareness of teaching science } \\
\text { for social justice in urban high schools. }\end{array}$ & $\begin{array}{l}\text { Qualitative methods through a case-study } \\
\text { approach. } \\
\text { Data sources: } 6 \text { individual semi-structured } \\
\text { interviews with } 4 \text { participants over a two- } \\
\text { year period, a focus group and written } \\
\text { reflections. }\end{array}$ \\
\hline $\begin{array}{l}\text { Mayo (2016) } \\
\text { Dissertation }\end{array}$ & $\begin{array}{l}\text { To examine the professional identity of } \\
\text { high school science teachers who take } \\
\text { on the role of district-based science } \\
\text { specialist through the experiences of } \\
11 \text { science teachers and six } \\
\text { administrators. }\end{array}$ & $\begin{array}{l}\text { Qualitative methods. } \\
\text { Data sources: electronic participant } \\
\text { questionnaire and two phases of semi- } \\
\text { structured interviews. }\end{array}$ \\
\hline $\begin{array}{l}\text { McIntyre and Hobson } \\
\text { (2016) RPE }\end{array}$ & $\begin{array}{l}\text { To explore the identity development of } \\
\text { beginning high school teachers of } \\
\text { physics who received support from } \\
\text { external mentors (experienced subject- } \\
\text { specialist teachers working at different } \\
\text { schools to their mentees). }\end{array}$ & $\begin{array}{l}\text { Qualitative methods. } \\
\text { Data sources: } 28 \text { semi-structured interviews } \\
\text { with beginning teachers, four case studies } \\
\text { of external mentors. }\end{array}$ \\
\hline $\begin{array}{l}\text { Mehli and Bungum } \\
\text { (2013) RSTE }\end{array}$ & $\begin{array}{l}\text { To examine how a short-term in- } \\
\text { service science course on a research } \\
\text { site of space technology can support } \\
\text { elementary, middle and high school } \\
\text { science teachers' deep understanding } \\
\text { of how science works in modern } \\
\text { society. }\end{array}$ & $\begin{array}{l}\text { Qualitative methods. } \\
\text { Data sources: survey responses from } 137 \\
\text { participants, repeated interviews at three } \\
\text { stages after completion of a short course } \\
\text { with } 14 \text { participants, observations of three } \\
\text { courses. The sample included elementary } \\
\text { science teachers but predominantly } \\
\text { comprised middle and high school science } \\
\text { teachers. }\end{array}$ \\
\hline $\begin{array}{l}\text { Melville et al. (2007) } \\
\text { JSET }\end{array}$ & $\begin{array}{l}\text { To examine the inter-relationships } \\
\text { between ten science teachers in an } \\
\text { Australian high school science } \\
\text { department over an academic year, and } \\
\text { to explore how the social space or } \\
\text { 'field' of their work and their } \\
\text { dispositions towards teacher leadership } \\
\text { shape individuals' sense of identity as } \\
\text { a science teacher. }\end{array}$ & $\begin{array}{l}\text { Qualitative methods. } \\
\text { Data sources: audio recordings of } \\
\text { departmental staff meetings held every six } \\
\text { weeks over a course of a year, documents } \\
\text { produced by staff including a letter and an } \\
\text { extract from a school newsletter. }\end{array}$ \\
\hline $\begin{array}{l}\text { Melville and Bartley } \\
\text { (2013) SCIED }\end{array}$ & $\begin{array}{l}\text { To examine the work of three high } \\
\text { school teachers who have constituted } \\
\text { identities that challenge the } \\
\text { contemporary discourse of science } \\
\text { education and to identify the situations }\end{array}$ & $\begin{array}{l}\text { Qualitative methods. } \\
\text { Data sources: semi-structured interviews. }\end{array}$ \\
\hline
\end{tabular}

Rushton, E. A. C. \& Reiss, M. J. (2020) Middle and high school science teacher identity considered through 81 the lens of the social identity approach: a systematic review of the literature. Studies in Science Education. DOI: $10.1080 / 03057267.2020 .1799621$. 


\begin{tabular}{|c|c|c|}
\hline & $\begin{array}{l}\text { that occur where teachers constitute } \\
\text { these identities. }\end{array}$ & \\
\hline $\begin{array}{l}\text { Melville et al. (2013) } \\
\text { IJSME }\end{array}$ & $\begin{array}{l}\text { To examine the impact of scaffolding } \\
\text { on preservice middle and high school } \\
\text { science teachers' constitution of } \\
\text { identities as teachers of inquiry. }\end{array}$ & $\begin{array}{l}\text { Qualitative, narrative methodology. } \\
\text { Data sources: semi-structured interviews } \\
\text { with } 31 \text { participants. }\end{array}$ \\
\hline $\begin{array}{l}\text { Molander and Hamza } \\
\text { (2018) JSTE }\end{array}$ & $\begin{array}{l}\text { To explore the development of } \\
\text { professional identity in six participants } \\
\text { during a fast-track high school science } \\
\text { teacher education program for career } \\
\text { changers with a doctorate in natural } \\
\text { sciences and work experience in the } \\
\text { science field. }\end{array}$ & $\begin{array}{l}\text { Qualitative methods. } \\
\text { Data sources, five semi-structured } \\
\text { individual interviews with each participant } \\
\text { over the course of the teacher education } \\
\text { program. }\end{array}$ \\
\hline Moore (2008) JRST & $\begin{array}{l}\text { To examine the experiences of three } \\
\text { African American high school science } \\
\text { teachers as they relate to both their } \\
\text { positional identity and development as } \\
\text { science teachers. }\end{array}$ & $\begin{array}{l}\text { Qualitative methods, narrative and life } \\
\text { history approaches. } \\
\text { Data sources: interview data with three } \\
\text { participants. }\end{array}$ \\
\hline $\begin{array}{l}\text { Nichols et al. (2017) } \\
\text { TTTP }\end{array}$ & $\begin{array}{l}\text { To examine the connections among } \\
\text { emotional episodes and the emerging } \\
\text { professional identities of eight first } \\
\text { year mathematics and science teachers } \\
\text { in urban high schools. }\end{array}$ & $\begin{array}{l}\text { Qualitative methods, grounded theory } \\
\text { approach. } \\
\text { Data sources: semi-structured individual } \\
\text { interviews. }\end{array}$ \\
\hline $\begin{array}{l}\text { Nieswandt et al. } \\
\text { (2013) CJSMTE }\end{array}$ & $\begin{array}{l}\text { To explore whether preservice high } \\
\text { school science teachers express } \\
\text { science-specific identities that reflect } \\
\text { multiple areas of belief and other } \\
\text { individual characteristics. }\end{array}$ & $\begin{array}{l}\text { Quantitative methods, hierarchical cluster } \\
\text { analysis. } \\
\text { Data sources: } 247 \text { responses to a } \\
\text { questionnaire. }\end{array}$ \\
\hline $\begin{array}{l}\text { Ortega et al. (2015) } \\
\text { PE }\end{array}$ & $\begin{array}{l}\text { To explore the professional } \\
\text { development and identity development } \\
\text { of preservice high school science } \\
\text { teachers through four case studies from } \\
\text { one university-based initial teacher } \\
\text { training program. }\end{array}$ & $\begin{array}{l}\text { Qualitative case study approach. } \\
\text { Data sources: personal meaning mapping } \\
\text { and individual interviews collected at the } \\
\text { beginning and end of a six-month period. }\end{array}$ \\
\hline $\begin{array}{l}\text { Pedretti et al. (2008) } \\
\text { SCI\&ED }\end{array}$ & $\begin{array}{l}\text { To explore } 64 \text { preservice high school } \\
\text { science teachers' responses to an } \\
\text { example of STSE teaching and to } \\
\text { explore how science teacher identities } \\
\text { intersect with STSE perspectives. }\end{array}$ & $\begin{array}{l}\text { Qualitative and quantitative methods. } \\
\text { Data sources: pre- and post-questionnaires, } \\
\text { open-ended surveys, reflective writing, } \\
\text { worksheets, recorded conversations, } \\
\text { interviews with } 64 \text { participants. }\end{array}$ \\
\hline $\begin{array}{l}\text { Proweller and } \\
\text { Mitchener (2004) } \\
\text { JRST }\end{array}$ & $\begin{array}{l}\text { To examine how } 15 \text { participants in an } \\
\text { alternative route to high school science } \\
\text { teacher qualification (through } \\
\text { internship) construct a professional } \\
\text { identity as science educators when } \\
\text { creating a quality and inclusive science } \\
\text { curriculum for urban youth. }\end{array}$ & $\begin{array}{l}\text { Qualitative methods. } \\
\text { Data sources: individual, structured } \\
\text { interviews, notes from weekly seminar } \\
\text { meetings, field notes of classroom } \\
\text { observations. }\end{array}$ \\
\hline $\begin{array}{l}\text { Richardson (2019) } \\
\text { Dissertation }\end{array}$ & $\begin{array}{l}\text { To examine the reasons why high } \\
\text { school science teachers remain in the } \\
\text { profession, drawing on the experiences } \\
\text { of twenty mid- and late-career science } \\
\text { teachers. }\end{array}$ & $\begin{array}{l}\text { Qualitative methods. } \\
\text { Data sources: semi-structured in-depth } \\
\text { interviews with } 20 \text { participants. }\end{array}$ \\
\hline $\begin{array}{l}\text { Richmond (2016) in } \\
\text { Avraamidou (2016) }\end{array}$ & $\begin{array}{l}\text { To explore the role of contexts, } \\
\text { specifically those found in high- }\end{array}$ & Qualitative methods. \\
\hline
\end{tabular}

Rushton, E. A. C. \& Reiss, M. J. (2020) Middle and high school science teacher identity considered through 82 the lens of the social identity approach: a systematic review of the literature. Studies in Science Education. DOI: $10.1080 / 03057267.2020 .1799621$. 


\begin{tabular}{|c|c|c|}
\hline & $\begin{array}{l}\text { poverty schools, in the development of } \\
\text { preservice high school science } \\
\text { teachers' identities and sense of } \\
\text { agency over the course of a two-year } \\
\text { study. }\end{array}$ & $\begin{array}{l}\text { Data sources: reconstructed narratives } \\
\text { drawn from a variety of first, second and } \\
\text { third person sources, collected from three } \\
\text { participants over the course of two years. }\end{array}$ \\
\hline Ritchie (2009) CSSE & $\begin{array}{l}\text { Re-examination of African American } \\
\text { high school science teacher identities } \\
\text { that contests the notion of } \\
\text { renegotiation of identities. }\end{array}$ & Theoretical paper. \\
\hline $\begin{array}{l}\text { Rivera Maulucci } \\
\text { (2008) CSSE }\end{array}$ & $\begin{array}{l}\text { To explore, through a case study, the } \\
\text { relationships between language and } \\
\text { core identity of an immigrant } \\
\text { preservice high school science teacher. }\end{array}$ & $\begin{array}{l}\text { Qualitative methods, narrative inquiry } \\
\text { approach. } \\
\text { Data sources: participant's teaching } \\
\text { autobiography, reading responses, portfolio } \\
\text { reflections, adolescent case study, social } \\
\text { justice curriculum unit plan. }\end{array}$ \\
\hline $\begin{array}{l}\text { Rivera Maulucci } \\
\text { (2013) JRST }\end{array}$ & $\begin{array}{l}\text { To explore the role of emotions and } \\
\text { social justice stance in the } \\
\text { development of one preservice high } \\
\text { school science teacher's identity as a } \\
\text { social justice chemistry teacher. }\end{array}$ & $\begin{array}{l}\text { Qualitative methods, case-study approach. } \\
\text { Data sources: material produced by the case } \\
\text { study participant as part of her teacher } \\
\text { training university course including written } \\
\text { teaching autobiographies, weekly reading } \\
\text { responses, reflective journal entries and } \\
\text { video-recorded classroom observations. }\end{array}$ \\
\hline $\begin{array}{l}\text { Rivera Maulucci } \\
\text { (2016) in Avraamidou } \\
\text { (2016) }\end{array}$ & $\begin{array}{l}\text { To explore the development of one } \\
\text { preservice high school science } \\
\text { teacher's identity over the course of a } \\
\text { year in the context of social justice } \\
\text { framings of teacher education. }\end{array}$ & $\begin{array}{l}\text { Qualitative methods, case study approach } \\
\text { focused on one preservice high school } \\
\text { science teacher. } \\
\text { Data sources: journal entries, reflection } \\
\text { papers, lesson plans and classroom } \\
\text { observations. }\end{array}$ \\
\hline $\begin{array}{l}\text { Rostock (2014) } \\
\text { (Dissertation) }\end{array}$ & $\begin{array}{l}\text { Explores the professional identity } \\
\text { development of three early-career high } \\
\text { school mathematics and science } \\
\text { teachers who participated in a five- } \\
\text { year long teacher fellowship program. }\end{array}$ & $\begin{array}{l}\text { Qualitative, narrative research methods, } \\
\text { case study approach focused on three } \\
\text { teachers. } \\
\text { Data sources: written narrative, individual } \\
\text { and group interviews. }\end{array}$ \\
\hline $\begin{array}{l}\text { Roth (2016) in } \\
\text { Avraamidou (2016) }\end{array}$ & $\begin{array}{l}\text { Drawing on autobiography, Roth } \\
\text { (2016) argues that identity should be } \\
\text { seen in the Deweyan category of } \\
\text { experience or the Vygotskian concept } \\
\text { of perezhivanie. This is in contrast to } \\
\text { understandings of identity that view a } \\
\text { person as a composite of micro- } \\
\text { identities. This new, 'experience } \\
\text { approach' provides an opportunity to } \\
\text { theorize identity as becoming in and } \\
\text { belonging to science teaching. }\end{array}$ & $\begin{array}{l}\text { Theoretical paper with an autobiographical, } \\
\text { socio-historical approach that draws on } \\
\text { different contexts, including Germany and } \\
\text { Canada. } \\
\text { Data sources: biographical accounts from } \\
\text { the career span of one high school science } \\
\text { teacher. }\end{array}$ \\
\hline $\begin{array}{l}\text { Rushton and Reiss } \\
\text { (2019) IJSE }\end{array}$ & $\begin{array}{l}\text { To examine the experiences of } 17 \\
\text { research active high school science } \\
\text { teachers and to explore the ways in } \\
\text { which these shape science teachers' } \\
\text { identities. }\end{array}$ & $\begin{array}{l}\text { Qualitative methods. } \\
\text { Data sources: semi-structured individual } \\
\text { interviews with } 17 \text { participants. }\end{array}$ \\
\hline Saka et al. (2013) RSE & $\begin{array}{l}\text { To explore through an individual case } \\
\text { study how a beginning high school } \\
\text { science teacher negotiates context, } \\
\text { practice and identity during induction } \\
\text { into a teaching career and how }\end{array}$ & $\begin{array}{l}\text { Qualitative methods, longitudinal } \\
\text { interpretative case study design. } \\
\text { Data sources: school observations, } \\
\text { questionnaires, semi-structured interviews, }\end{array}$ \\
\hline
\end{tabular}

Rushton, E. A. C. \& Reiss, M. J. (2020) Middle and high school science teacher identity considered through 83 the lens of the social identity approach: a systematic review of the literature. Studies in Science Education.

DOI: $10.1080 / 03057267.2020 .1799621$. 


\begin{tabular}{|c|c|c|}
\hline & $\begin{array}{l}\text { interaction with context shapes reform- } \\
\text { minded teaching practice. }\end{array}$ & $\begin{array}{l}\text { teaching artefacts (e.g. lesson plans, } \\
\text { assessments). }\end{array}$ \\
\hline Seiler (2011) CSSE & $\begin{array}{l}\text { To explore the identity hybridization } \\
\text { of science teachers from 'non- } \\
\text { dominant' or ethnic minority groups, } \\
\text { with multiple identity narratives that } \\
\text { are developed both in and outside } \\
\text { school and the possibilities for greater } \\
\text { student engagement. }\end{array}$ & $\begin{array}{l}\text { Qualitative methods, narrative, reflective } \\
\text { approach. } \\
\text { Data sources: interviews, reflections and } \\
\text { video vignettes of classroom observations } \\
\text { from three high school science teachers } \\
\text { from 'non-dominant' groups. }\end{array}$ \\
\hline $\begin{array}{l}\text { Sinha and Hanuscin } \\
\text { (2017) TTE }\end{array}$ & $\begin{array}{l}\text { To investigate the processes and } \\
\text { pathways of leadership development of } \\
\text { teachers at different career stages as } \\
\text { they participated in a professional } \\
\text { development program. }\end{array}$ & $\begin{array}{l}\text { Qualitative methods, case study approach. } \\
\text { Data sources: interviews with three high } \\
\text { school science teacher case study } \\
\text { participants, documents (e.g. blogs, } \\
\text { application form, life story exercise). }\end{array}$ \\
\hline $\begin{array}{l}\text { Snyder et al. (2013) } \\
\text { JSTE }\end{array}$ & $\begin{array}{l}\text { To explore over three years the } \\
\text { professional development of four } \\
\text { female career-changing high school } \\
\text { science teachers and to examine } \\
\text { identity formation. }\end{array}$ & $\begin{array}{l}\text { Qualitative methods, case study approach. } \\
\text { Data sources: interviews, 12-month long } \\
\text { reflective journal, email correspondence } \\
\text { with researchers and participant-generated } \\
\text { photography. }\end{array}$ \\
\hline $\begin{array}{l}\text { Subryan (2016) } \\
\text { Dissertation }\end{array}$ & $\begin{array}{l}\text { To explore the influence of } \\
\text { participation in professional } \\
\text { development programmes on } 13 \text { high } \\
\text { school science teachers' professional } \\
\text { identities. }\end{array}$ & $\begin{array}{l}\text { Qualitative methods. } \\
\text { Data sources: narrative interviews, semi- } \\
\text { structured interviews, questionnaire. }\end{array}$ \\
\hline $\begin{array}{l}\text { Varelas et al. (2005) } \\
\text { SCIED }\end{array}$ & $\begin{array}{l}\text { To explore the ways in which four } \\
\text { beginning high school science teachers } \\
\text { identify as scientists and science } \\
\text { teachers during and after a } 10 \text {-week } \\
\text { apprenticeship at a science laboratory. }\end{array}$ & $\begin{array}{l}\text { Qualitative methods. } \\
\text { Data sources: multiple interviews with each } \\
\text { of the four participants. }\end{array}$ \\
\hline $\begin{array}{l}\text { Watters and Diezmann } \\
\text { (2015) SCIED }\end{array}$ & $\begin{array}{l}\text { To examine the experiences of } 14 \\
\text { career-changing scientists who } \\
\text { participated in a one-year preservice } \\
\text { teacher education course in order to } \\
\text { teach science in high school after } \\
\text { graduation. }\end{array}$ & $\begin{array}{l}\text { Qualitative methods, multiple case study } \\
\text { approach. } \\
\text { Data sources: interviews (telephone and in } \\
\text { person) throughout the one-year course, } \\
\text { videotaping of lessons and joint reflections } \\
\text { on videoed lessons made by participant and } \\
\text { researcher, school visits made by } \\
\text { researcher. }\end{array}$ \\
\hline $\begin{array}{l}\text { Webb (2012) } \\
\text { Dissertation }\end{array}$ & $\begin{array}{l}\text { To explore the identity formation of } \\
\text { four first-year high school science } \\
\text { teachers during their induction } \\
\text { activities and classroom science } \\
\text { teaching. }\end{array}$ & $\begin{array}{l}\text { Qualitative methods. } \\
\text { Data sources: interviews and observations } \\
\text { of teaching, mentor/mentee meetings, } \\
\text { induction activities, and professional } \\
\text { learning community activities. }\end{array}$ \\
\hline $\begin{array}{l}\text { West (2015) } \\
\text { Dissertation }\end{array}$ & $\begin{array}{l}\text { To explore the formation of high } \\
\text { school science teacher identity and } \\
\text { self-efficacy in student teachers } \\
\text { enrolled in an alternative teacher } \\
\text { training program. }\end{array}$ & $\begin{array}{l}\text { Qualitative and quantitative methods. } \\
\text { Data sources: pre- and post-test } \\
\text { administrations of the Teacher Sense of } \\
\text { Efficacy Scale (TSES); interviews with } \\
\text { participants. }\end{array}$ \\
\hline $\begin{array}{l}\text { Whitacre (2015) } \\
\text { Dissertation }\end{array}$ & $\begin{array}{l}\text { To examine the experiences of five } \\
\text { high school science teachers who } \\
\text { participated in a professional } \\
\text { development program focused on } \\
\text { science literacy and how this shaped } \\
\text { their professional identity. }\end{array}$ & $\begin{array}{l}\text { Qualitative methods, conceptual approach } \\
\text { includes transformative learning theory, } \\
\text { communities of practice and sociocultural } \\
\text { conceptions of identity. } \\
\text { Data sources: data from surveys and } \\
\text { phenomenological interviews. }\end{array}$ \\
\hline
\end{tabular}

Rushton, E. A. C. \& Reiss, M. J. (2020) Middle and high school science teacher identity considered through 84 the lens of the social identity approach: a systematic review of the literature. Studies in Science Education.

DOI: $10.1080 / 03057267.2020 .1799621$. 


\begin{tabular}{|l|l|l|}
\hline $\begin{array}{l}\text { Wilson and Deaney } \\
\text { (2011) SPEIJ }\end{array}$ & $\begin{array}{l}\text { To explore the development of teacher } \\
\text { identity through an 18-month long case } \\
\text { study of one mature, highly qualified } \\
\text { science graduate as she moved through } \\
\text { initial teacher education and into her } \\
\text { first teaching post as a high school } \\
\text { science teacher. }\end{array}$ & $\begin{array}{l}\text { Qualitative methods, case study approach. } \\
\text { Data sources: reflective blog entries written } \\
\text { by the participant, mentor reports, } \\
\text { interviews. }\end{array}$ \\
\hline $\begin{array}{l}\text { Woolhouse and } \\
\text { Cochrane (2015) EJTE }\end{array}$ & $\begin{array}{l}\text { To explore the development of trainee } \\
\text { high school science teachers' } \\
\text { professional identities during subject- } \\
\text { specific training. }\end{array}$ & $\begin{array}{l}\text { Qualitative and quantitative methods. } \\
\text { Data sources: quantitative and qualitative } \\
\text { responses from 159 trainee teachers to a } \\
\text { survey and focus groups with 40 trainee } \\
\text { teachers. }\end{array}$ \\
\hline
\end{tabular}


Table 2. Journals included in the study

\begin{tabular}{lr}
\hline Journal title & $\begin{array}{c}\text { Number } \\
\text { of } \\
\text { articles }\end{array}$ \\
\hline Cultural Studies in Science Education (CSSE) & 9 \\
Science Education (SCIED) & 6 \\
Journal of Science Teacher Education (JSTE) & 6 \\
Journal of Research in Science Teaching (JRST) & 6 \\
International Journal of Science Education (IJSE) & 3 \\
Teaching and Teacher Education (TTE) & 3 \\
Canadian Journal of Science, Mathematics and Technology Education & 2 \\
(CJSMTE) & \\
Curriculum Journal (CJ) & 1 \\
Educational Perspectives (EP) & 1 \\
Electronic Journal of Science Education (EJSE) & 1 \\
Eurasia Journal of Mathematics, Science \& Technology Education (EJMSTE) & 1 \\
European Journal of Teacher Education (EJTE) & 1 \\
International Journal of Science and Mathematics Education (IJSME) & 1 \\
International Journal of STEM Education (IJStemE) & 1 \\
Journal of Education for Teaching (JET) & 1 \\
Journal of Learning Studies (JLS) & 1 \\
Journal of Science Education and Technology (JSET) & 1 \\
Journal of Teacher Education (JTE) & 1 \\
Perspectiva Educacional (PE) & 1 \\
Research Papers in Education (RPE) & 1 \\
Research in Science Education (RSE) & 1 \\
Research in Science and Technological Education (RSTE) & 1 \\
Science \& Education (SCI\&ED) & 1 \\
Social Psychology of Education: An International Journal (SPEIJ) & 1 \\
Studies in Science Education (SSE) & 1 \\
Teachers and Teaching: Theory and Practice (TTTP) & 1 \\
Teachers and Teaching (TT) & 1 \\
Total & 1 \\
& 1 \\
& 1 \\
& 1 \\
& 1 \\
&
\end{tabular}

Rushton, E. A. C. \& Reiss, M. J. (2020) Middle and high school science teacher identity considered through 86 the lens of the social identity approach: a systematic review of the literature. Studies in Science Education. DOI: $10.1080 / 03057267.2020 .1799621$. 
Table 3. Country of study.

\begin{tabular}{l|l}
\hline Country & Publications \\
\hline Australia & 3 \\
Brazil & 1 \\
Canada & 6 \\
Chile & 1 \\
Netherlands & 1 \\
New Zealand & 1 \\
Norway & 1 \\
Sweden & 1 \\
UK & 7 \\
USA & 52 \\
More than one country & 5 \\
Total & $\mathbf{7 9}$
\end{tabular}

Rushton, E. A. C. \& Reiss, M. J. (2020) Middle and high school science teacher identity considered through 87 the lens of the social identity approach: a systematic review of the literature. Studies in Science Education. DOI: $10.1080 / 03057267.2020 .1799621$. 
Table 4. Grouping of literature

\begin{tabular}{|c|c|c|c|}
\hline Group name & \multicolumn{2}{|l|}{ Literature } & $\begin{array}{l}\text { Number of } \\
\text { publications } \\
\text { (post 2014) }\end{array}$ \\
\hline \multirow[t]{4}{*}{$\begin{array}{l}\text { Group one - Studies } \\
\text { that broadly consider } \\
\text { identity development } \\
\text { in science teachers }\end{array}$} & Preservice teachers & $\begin{array}{l}\text { Chung-Bailey and Parsons } \\
\text { (2019); Dominguez et al. } \\
\text { (2015); Hong et al. (2017); } \\
\text { Hsu et al. (2017); Irving-Bell } \\
\text { (2018); Kang (2011); } \\
\text { Nieswandt et al. (2013); } \\
\text { Ortega et al. (2015); } \\
\text { Woolhouse and Cochrane } \\
\text { (2015) }\end{array}$ & \multirow[t]{4}{*}{$21(16)$} \\
\hline & Qualified teachers & $\begin{array}{l}\text { Beijaard et al. (2000); } \\
\text { Deneroff (2016); El Nagi et } \\
\text { al. (2018); Manning (2017); } \\
\text { Nichols et al. (2017); } \\
\text { Richardson (2019) }\end{array}$ & \\
\hline & $\begin{array}{l}\text { Models of identity } \\
\text { development }\end{array}$ & $\begin{array}{l}\text { Chi (2009); Garner and } \\
\text { Kaplan (2018); Garner et al. } \\
(2016)\end{array}$ & \\
\hline & $\begin{array}{l}\text { Theoretical } \\
\text { considerations of } \\
\text { identity }\end{array}$ & $\begin{array}{l}\text { Avraamidou (2014a); Glass } \\
\text { (2019); Roth (2016) }\end{array}$ & \\
\hline \multirow{4}{*}{$\begin{array}{l}\text { Group two - Studies } \\
\text { that focus on a } \\
\text { specific aspect of a } \\
\text { teacher's own } \\
\text { context or experience }\end{array}$} & $\begin{array}{l}\text { Contrasting and } \\
\text { diverse cultural } \\
\text { contexts - } \\
\text { preservice teachers }\end{array}$ & $\begin{array}{l}\text { Brand and Glasson (2004); } \\
\text { Edwards and Edwards } \\
\text { (2017); Rivera Maulucci } \\
(2008)\end{array}$ & \multirow[t]{4}{*}{$18(7)$} \\
\hline & $\begin{array}{l}\text { Contrasting and } \\
\text { diverse cultural } \\
\text { contexts - qualified } \\
\text { teachers }\end{array}$ & $\begin{array}{l}\text { Allaire (2013); Blackwell } \\
\text { (2012); Childs (2018); } \\
\text { Fitzgerald (2018); Kitonga } \\
\text { (2011); Moore (2008); Seiler } \\
\text { (2011) }\end{array}$ & \\
\hline & $\begin{array}{l}\text { Theoretical } \\
\text { discussions of } \\
\text { identity in diverse } \\
\text { socio-cultural } \\
\text { contexts }\end{array}$ & $\begin{array}{l}\text { Harrison (2018); Ritchie } \\
(2009)\end{array}$ & \\
\hline & $\begin{array}{l}\text { Teachers who are } \\
\text { career changers }\end{array}$ & $\begin{array}{l}\text { Antink-Meyer and Brown } \\
\text { (2017); Grier and Johnston } \\
\text { (2009); Molander and Hamza } \\
\text { (2018); Snyder et al. (2013); } \\
\text { Watters and Diezmann } \\
\text { (2015); Wilson and Deaney } \\
\text { (2010) }\end{array}$ & \\
\hline $\begin{array}{l}\text { Group three - } \\
\text { Studies that focus on } \\
\text { an aspect of the }\end{array}$ & Preservice teachers & $\begin{array}{l}\text { Dreon (2011); Eick and Reed } \\
\text { (2002); Melville et al. } \\
\text { (2013); Pedretti et al. (2008) }\end{array}$ & $10(3)$ \\
\hline
\end{tabular}

Rushton, E. A. C. \& Reiss, M. J. (2020) Middle and high school science teacher identity considered through 88 the lens of the social identity approach: a systematic review of the literature. Studies in Science Education. DOI: $10.1080 / 03057267.2020 .1799621$. 


\begin{tabular}{|c|c|c|c|}
\hline \multirow[t]{2}{*}{$\begin{array}{l}\text { school and/or } \\
\text { teaching context }\end{array}$} & Qualified teachers & $\begin{array}{l}\text { Bang \& Luft (2016); Drewes } \\
\text { (2018); Enyedy et al. (2005); } \\
\text { Melville et al. (2007); Webb } \\
\text { (2012) }\end{array}$ & \\
\hline & Theoretical studies & Bryce et al. (2016); & \\
\hline \multirow[t]{2}{*}{$\begin{array}{l}\text { Group four - Studies } \\
\text { that consider the role } \\
\text { of the training } \\
\text { programme }\end{array}$} & & $\begin{array}{l}\text { Adam and Gupta (2015); } \\
\text { Danielowich (2012); Eick } \\
\text { (2009); Friedrichsen et al., } \\
\text { (2008); Heredia and Yu } \\
\text { (2017); Ibourk (2015); } \\
\text { Luehmann (2016); Marco- } \\
\text { Bujosa et al. (2019); } \\
\text { McIntyre and Hobson } \\
\text { (2016); Proweller and } \\
\text { Mitchener (2004); Richmond } \\
\text { (2016); Rivera Maulucci } \\
\text { (2013); Rivera Maulucci and } \\
\text { Fann (2016); West (2015) }\end{array}$ & \multirow[t]{2}{*}{$15(9)$} \\
\hline & Theoretical study & Luehmann (2007) & \\
\hline \multirow[t]{5}{*}{$\begin{array}{l}\text { Group five }- \text { Studies } \\
\text { that consider the role } \\
\text { of professional } \\
\text { development } \\
\text { opportunities }\end{array}$} & $\begin{array}{l}\text { Reform-minded } \\
\text { science education }\end{array}$ & $\begin{array}{l}\text { Melville and Bartley (2013); } \\
\text { Sakar et al. (2013); Rostock } \\
\text { (2014); Subryan (2016); } \\
\text { Guzey and Ring-Wahlen } \\
\text { (2018) }\end{array}$ & \multirow[t]{5}{*}{$15(8)$} \\
\hline & Leadership & $\begin{array}{l}\text { Mayo (2016) Hanuscin et al. } \\
\text { (2016); Sinha and Hanuscin } \\
(2017)\end{array}$ & \\
\hline & $\begin{array}{l}\text { STEM-based } \\
\text { research }\end{array}$ & $\begin{array}{l}\text { Varelas et al. (2005); Mehli } \\
\text { and Bungum (2013); } \\
\text { Rushton and Reiss (2019) }\end{array}$ & \\
\hline & Science literacy & Whitacre (2015) & \\
\hline & Blogging & $\begin{array}{l}\text { Luehmann (2008); Hanuscin } \\
\text { et al. (2014) }\end{array}$ & \\
\hline Total & & 79 (43) & \\
\hline
\end{tabular}

Rushton, E. A. C. \& Reiss, M. J. (2020) Middle and high school science teacher identity considered through 89 the lens of the social identity approach: a systematic review of the literature. Studies in Science Education. DOI: $10.1080 / 03057267.2020 .1799621$. 